\title{
Lifetime Impact of Cow's Milk on Overactivation of mTORC1: From Fetal to Childhood Overgrowth, Acne, Diabetes, Cancers, and Neurodegeneration
}

\author{
Bodo C. Melnik
}

check for

updates

Citation: Melnik, B.C. Lifetime

Impact of Cow's Milk on

Overactivation of mTORC1: From

Fetal to Childhood Overgrowth,

Acne, Diabetes, Cancers, and

Neurodegeneration. Biomolecules

2021, 11, 404. https://doi.org/

10.3390/biom11030404

Academic Editors: Kazuhiro Shiozaki and Ted Powers

Received: 31 January 2021

Accepted: 4 March 2021

Published: 9 March 2021

Publisher's Note: MDPI stays neutral with regard to jurisdictional claims in published maps and institutional affiliations.

Copyright: (C) 2021 by the author. Licensee MDPI, Basel, Switzerland. This article is an open access article distributed under the terms and conditions of the Creative Commons Attribution (CC BY) license (https:/ / creativecommons.org/licenses/by/ $4.0 /)$.
Department of Dermatology, Environmental Medicine and Health Theory, University of Osnabrück, Am Finkenhügel 7a, D-49076 Osnabrück, Germany; melnik@t-online.de; Tel.: +49-5241-988-060

\begin{abstract}
The consumption of cow's milk is a part of the basic nutritional habits of Western industrialized countries. Recent epidemiological studies associate the intake of cow's milk with an increased risk of diseases, which are associated with overactivated mechanistic target of rapamycin complex 1 (mTORC1) signaling. This review presents current epidemiological and translational evidence linking milk consumption to the regulation of mTORC1, the master-switch for eukaryotic cell growth. Epidemiological studies confirm a correlation between cow's milk consumption and birthweight, body mass index, onset of menarche, linear growth during childhood, acne vulgaris, type 2 diabetes mellitus, prostate cancer, breast cancer, hepatocellular carcinoma, diffuse large B-cell lymphoma, neurodegenerative diseases, and all-cause mortality. Thus, long-term persistent consumption of cow's milk increases the risk of mTORC1-driven diseases of civilization. Milk is a highly conserved, lactation genome-controlled signaling system that functions as a maternal-neonatal relay for optimized species-specific activation of mTORC1, the nexus for regulation of eukaryotic cell growth, and control of autophagy. A deeper understanding of milk's impact on mTORC1 signaling is of critical importance for the prevention of common diseases of civilization.
\end{abstract}

Keywords: acne vulgaris; amino acids; cancer; diabetes mellitus; growth; milk; milk exosomal microRNAs; mortality; mTORC1; neurodegeneration

\section{Introduction}

The health-related effects of cow milk consumption by humans has been the focus of recent epidemiological research [1,2]. Milk is a substantial component of nutrition in Western industrialized countries. For instance, the annual per capita milk consumption in Germany was $49.5 \mathrm{~L}$ in 2019 [3]. Milk consumption is even higher in Scandinavian countries. The annual per capita milk consumption in Sweden declined from 2007 to 2018, from $130.5 \mathrm{~L}$ to $98.2 \mathrm{~L}$ [4]. In contrast, milk consumption in Asian countries is much lower. However, China's per capita milk consumption increased in recent years. In 2019, Chinese consumed on average $12.5 \mathrm{~kg}$ of milk and dairy products per person [5].

There is accumulating evidence that milk, the secretory product of mammary glands promoting growth and anabolism of newborn mammals, is not a simple food, but a signaling system activating the nutrient- and growth factor-sensitive kinase mechanistic target of rapamycin complex 1 (mTORC1) [6,7].

mTORC1 is an evolutionary conserved Ser/Thr protein kinase that senses multiple upstream stimuli to control cell growth, metabolism, and autophagy. mTOR is the catalytic subunit of mTOR complex 1 (mTORC1). A significant amount of research has uncovered the signaling pathways regulated by mTORC1, and the involvement of these signaling cascades in human diseases, such as cancer, diabetes, and aging [8].

It is important to realize that large-scale consumption of fresh cow's milk is a novel human behavior introduced by the availability of pasteurization and refrigeration technology [9]. Since the Neolithic revolution, over 10,000 years of preferentially fermented 
milk (yogurt, cheese) were the predominant milk products consumed by humans. Recent evidence has suggested that microbial fermentation of milk attenuates milk-mediated mTORC1 signaling, extensively reviewed elsewhere [9].

It is the intention of this review to present epidemiological and translational evidence that links milk consumption to mTORC1-driven pathologies and diseases of civilization. To understand milk's impact on mTORC1 activation, a brief introduction of milk-derived signals promoting mTORC1 signaling will be provided first. Then, milk's effects on mTORC1 signaling beginning from fetal growth, childhood, puberty, adolescence, and senescence will be presented.

\section{Milk: A Relay for mTORC1-Activation of the Milk Recipient}

Human breastmilk is the physiological and exclusive secretory product of the human mammary gland, supporting postnatal growth and appropriate metabolic programming of the newborn infant. Human breastmilk is evolutionarily adapted to meet the optimal species-specific growth requirements of the infant, resulting in the World Health Organization (WHO) recommendation of exclusive breastfeeding for six months [10]. Whereas formula feeding is an artificial attempt to imitate human breastmilk, recent pediatric research acknowledges the advantages of breastfeeding for approaching desirable growth trajectories and favorable metabolic long-term outcomes [11,12]. Surprisingly, when human milk composition is discussed in relation to infant growth, milk macronutrients, hormones, milk oligosaccharides, micronutrients, microbiota, and other bioactive components [13], these compounds have not been related to the cell's central activator of growth and anabolism, the kinase mTORC1 [14-19]. However, to understand milk-mediated growth and anabolism, milk-signaling interaction with mTORC1 of the milk recipient has to be appreciated. Milk consumption activates five major pathways stimulating mTORC1 via (1) growth factors, including growth hormone $(\mathrm{GH})$, insulin, and insulin-like growth factor 1 (IGF-1), (2) amino acids, especially branched-chain amino acids (BCAAs), (3) milk fatderived palmitic acid, $(4)$ the milk sugar lactose ( $\beta$-D-galactopyranosyl-( $1 \rightarrow 4)$-D-glucose, and (5) epigenetic modifiers, especially milk exosome (MEX)-derived micro-ribonucleic acids (miRs).

\subsection{Milk-Induced Growth Factor Signaling}

\subsubsection{Growth Hormone and Insulin-Like Growth Factor-1}

Milk consumption enhances growth hormone (GH) levels in children and peak GH levels in adults [20,21], as well as circulating IGF-1 levels in children and adults [20-26]. IGF-1 is a component of human and bovine milk [27-29]. Notably, the amino acid sequence of human and bovine IGF-1 are identical [30]. The GH-IGF-1 axis not only plays a key role for the physiological growth during childhood [30-32], but is also involved in milk production of dairy cows [33]. Administration of bovine GH (banned in the European Union) to dairy cows results in increased IGF-1 milk levels [34]. It is noteworthy to mention that it is not the oral uptake of bovine GH and bovine IGF-1 in milk that increases serum IGF-1 levels of milk consumers, but predominantly milk's inductive effect on hepatic IGF-1 synthesis [20,29]. Milk-induced increases in GH signaling via the GH receptor (GHR) and milk protein-derived amino acids, especially tryptophan, methionine, and arginine, enhances hepatic IGF-1 synthesis and secretion [20,35-41], resulting in enhanced IGF-1 mediated linear growth [42-44]. Tryptophan, a major component of milk proteins, is the precursor of serotonin (5-hydroxytryptamine, 5-HT), which, via 5-HT2 receptors, stimulates hypothalamic growth hormone releasing hormone $(\mathrm{GHRH})$ release and pituitary GH secretion increasing serum GH levels [45]. GH binding to hepatic GH receptor (GHR) is the major mechanism increasing circulatory levels of IGF-1 [46,47]. IGF-1, after binding to IGF-1 receptor (IGF1R), activates the phosphoinositide-3 kinase (PI3K)-AKT pathway, which phosphorylates tuberin (TSC2) resulting in dissociation of TSC2 from the lysosomal membrane. This results in the activation of RAS homolog enriched in the brain (RHEB), which finally activates mTORC1 [16,19,48-52] (Figure 1). 


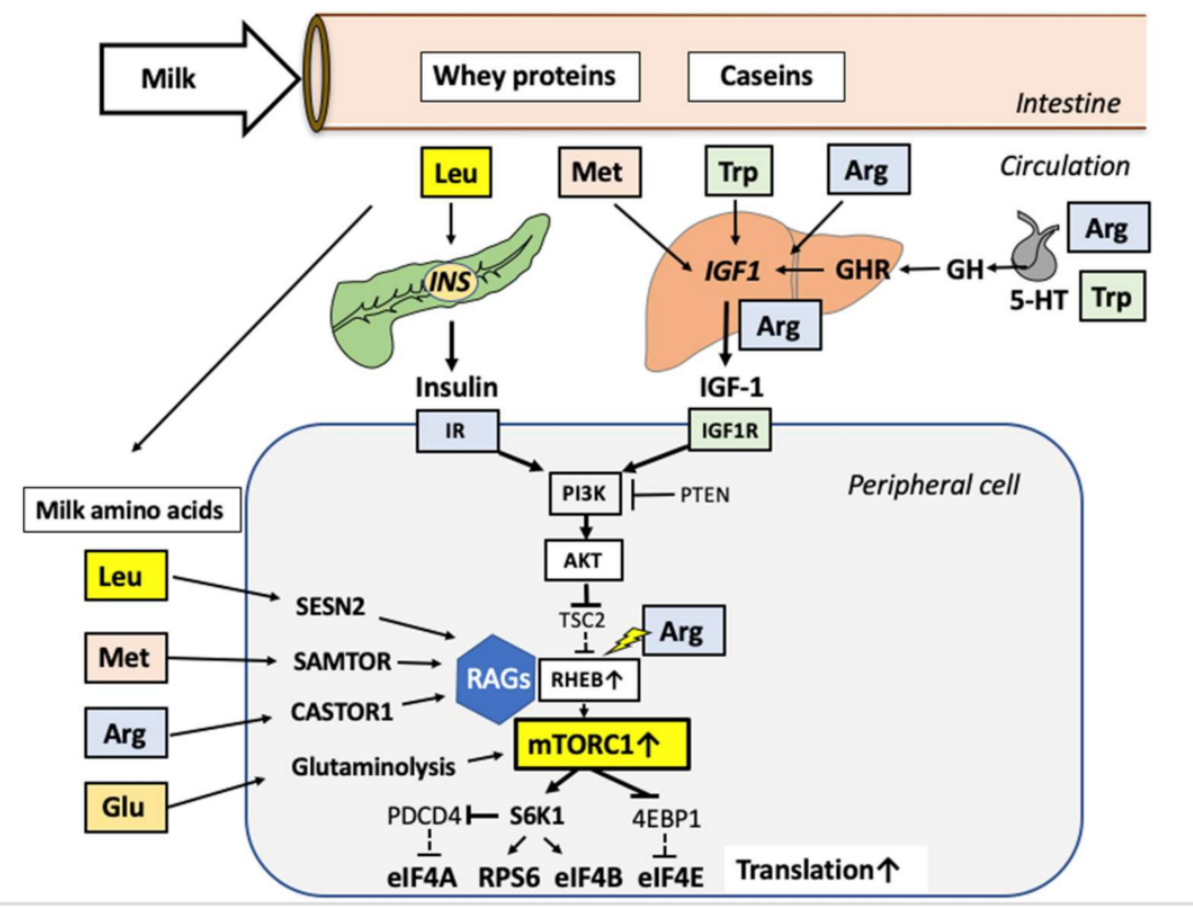

Figure 1. Model of milk amino acid signaling activating mTORC1 directly via amino acid-RAG interaction and insulin/IGF-1/PI3K/AKT signaling activating RHEB at the lysosomal membrane. Abbreviations: GH: growth hormone; GHR: growth hormone receptor; 5-HT: 5-hydroxy-tryptamine; INS: insulin gene; IR: insulin receptor; IGF1: IGF-1 gene; IGF-1: insulin-like growth factor 1; IGF1R: IGF-1 receptor; PI3K: phosphoinositide-3-kinase; PTEN: phosphatase and tensin homolog; AKT: Akt kinase (protein kinase B); TSC2: tuberin; SESN2: sestrin 2; SAMTOR: S-adenosylmethionine sensor upstream of mTOR; CASTOR1: cellular arginine sensor for mTORC1; RHEB: ras homolog enriched in brain. RAG: ras-related GTP binding protein; $\mathrm{mTORC1:} \mathrm{mechanistic} \mathrm{target} \mathrm{of} \mathrm{rapapmycin}$ complex 1; PDCD4: programmed cell death 4, S6K1: ribosomal protein S6 kinase 1; 4EBP1: eukaryotic translation initiationfactor 4E-binding protein 1; eIF4A: eukaryotic translation initiation factor 4A; RPS6: ribosomal protein S6; eIF4B: eukaryotic translation initiation factor 4A; eIF4E: eukaryotic translation initiation factor 4A; Leu: leucine; Met: methionine; Arg: arginine; Glu: glutamine; Trp: tryptophan.

\subsubsection{Insulin}

Insulinotropic BCAAs of milk are released by milk protein hydrolysis in the intestine and induce postprandial hyperinsulinemia. That is why the insulinemic index of milk is three times higher than milk's glycemic index [53,54]. Predominantly, whey protein-derived amino acids released after fast intestinal hydrolysis are responsible for the insulinemic effect of milk [55-59]. Insulin and IGF-1 synergistically activate PI3K-AKT-mTORC1 signaling, growth, and anabolism [49,51,60-65].

\subsection{Milk-Derived Amino Acids}

Among other animal or plant proteins, milk protein represents the richest source of BCAAs (Table 1). Milk and casein contain high amounts of methionine. In comparison to meat, whey proteins contain highest amounts of leucine $[66,67]$. In comparison to beef (glutamine $4.75 \mathrm{~g} / 100 \mathrm{~g}$ protein), milk protein has a high glutamine content $(8.1 \mathrm{~g} / 100 \mathrm{~g}$ protein) [68]. Glutamine via the glutaminolysis pathway also activates mTORC1 [69,70]. In comparison to plant and meat proteins, milk proteins (and especially whey proteins) exhibit an accelerated intestinal hydrolysis with increased postprandial concentrations of milk protein-derived amino acids that activate mTORC1 [59,71,72]. 
Table 1. Amino acid composition of milk proteins compared to aninmal- and plant-based protein sources ( $\mathrm{g}$ amino acids/100 g protein).

\begin{tabular}{cccccccccccc}
\hline Amino acid & Milk & Casein & Whey & Cod & Chicken & Egg & Beef & Pork & Lentil & Bean & Soy \\
\hline Leucine & 10.4 & 10.4 & 11.1 & 8.28 & 7.41 & 8.4 & 8.09 & 7.61 & 9.02 & 8.35 & 7.34 \\
Isoleucine & 6.4 & 5.7 & 6.8 & 4.65 & 5.43 & 6.22 & 4.98 & 4.95 & 5.08 & 4.55 & 4.66 \\
Valine & 6.8 & 6.8 & 6.8 & 5.34 & 5.06 & 7.48 & 5.43 & 5.62 & 5.94 & 5.12 & 4.61 \\
Tryptophan & 1.4 & 1.4 & 2.1 & 1.18 & 1.3 & 1.51 & 1.12 & 1.19 & 1.07 & 0.99 & 1.18 \\
Methionine & 2.8 & 2.9 & 2.2 & 2.94 & 2.67 & 3.03 & 2.47 & 2.79 & 0.94 & 1.24 & 1.52 \\
Arginine & 3.7 & 4 & 3 & 5.93 & 6.48 & 5.97 & 5.99 & 5.97 & 9.57 & 6.36 & 6.181 \\
Glutamine $^{*}$ & 8.1 & n.d. & n.d. & n.d. & n.d. & 4.43 & 4.75 & n.d. & n.d. & n.d. & 9.14 \\
\hline
\end{tabular}

Amino acid data according to [66] and glutamine data * [68]; n.d.= not determined.

Major amino acids of milk proteins, such as leucine, arginine, and methionine are sensed via sestrin 2 (SESN2), cellular arginine sensor for mTORC1 (CASTOR1), and Sadenosylmethionine sensor upstream of mTOR (SAMTOR), respectively. They orchestrate mTORC1 activation through the well-characterized RAG GTPase signaling pathways [73-88]. Binding between active RAG GTPase complexes and Raptor recruit the complex to the lysosomal membrane [73-88]. Glutamine activates mTORC1 through a RAG GTPaseindependent mechanism that requires ADP-ribosylation factor 1 (ARF1) [89]. Leucyl-tRNA synthetase (LRS) is another amino acid-dependent regulator of TORC1 [90-92]. LRS plays a critical role in amino acid-induced mTORC1 activation by sensing intracellular leucine concentration and initiating molecular events leading to mTORC1 activation. LRS directly binds to RAG GTPase, the mediator of amino acid signaling to mTORC1, in an amino aciddependent manner and functions as a GTPase-activating protein (GAP) for RAG GTPase to activate mTORC1 [92]. In addition, LRS functions as a leucine sensor for the activation of the class III PI3K Vps34 that mediates amino acid signaling to mTORC1 by regulating lysosomal translocation and activation of the phospholipase PLD1 [93]. Direct visualization of leucine sensing and LRS translocation to the lysosome was related to a crosstalk between leucine sensing, LRS translocation, RAGD interaction, and mTORC1 activation [94]. Recent evidence indicates a role of LRS1 in glucose-dependent control of leucine usage. Upon glucose starvation, LRS1 was phosphorylated by unc- 51 like autophagy activating kinase 1 (ULK1) at the residues crucial for leucine binding. The phosphorylated LRS1 exhibits decreased leucine binding, which may inhibit protein synthesis and help save energy [95].

Furthermore, arginine interferes with the TSC-RHEB complex relieving allosteric inhibition of RHEB by TSC [96]. Thus, arginine cooperates with growth factor signaling, which further promotes dissociation of TSC2 from lysosomes and activation of mTORC1 [96].

According to current consensus, mTORC1 is only activated when both RAG and RHEB GTPase activation pathways are fully activated, neither being sufficient in isolation [87]. RHEB and RAGs, the final activators of growth factor and amino acids signaling pathways, come together at the lysosome to activate mTORC1 [71-88,97].

\subsection{Milk Lipids}

The predominant fatty acid of milk triacylglycerols (TAGs), transported via milk fat globules (MFGs), is the saturated fatty acid palmitic acid (C16:0) [98-100]. MFG is a rapid conveyor of energy through its TAG core [101]. Palmitic acid, which after intestinal TAG hydrolysis and re-esterification into chylomicrons serves as an energy source, when catabolized by mitochondrial $\beta$-oxidation generates ATP [102,103]. ATP via inhibition of AMP-activated protein kinase (AMPK) activates mTORC1 at the lysosome [104-106]. Findings in skeletal muscle cells indicate that palmitate activates mTORC1/p70S6K signaling by AMPK inhibition and phosphorylation of Raptor [107]. Recent evidence supports the involvement of palmitic acid in mTORC1 activation at the lysosome $[108,109]$.

Palmitate activates mTORC1 by enhancing the recruitment of mTOR onto lysosomal membranes, which is inhibited by co-incubation with oleate or eicosapentaenoic acid [108]. Recent evidence indicates that protein palmitoylation is potentially involved 
in palmitate-induced mTORC1 activation, whereas 2-bromopalmitate, a protein palmitoylation inhibitor, ameliorated palmitate-triggered mTORC1 activation [110]. Furthermore, MFG membrane proteins, predominantly MFG-E8, promote cell proliferation through the PI3K/AKT/mTORC1 signaling pathway [111,112].

\subsection{Lactose}

After the breastfeeding period, the mucosal expression of lactase, the intestinal enzyme hydrolyzing lactose into glucose and galactose is downregulated in all mammals with the exception of Neolithic humans, who developed LCT mutations allowing persistent lactase expression [113]. The lactose content of milk makes up around $2-8 \%$ by weight. Lactose hydrolysis provides glucose and galactose, which both activate mTORC1.

During glucose abundance and glycolysis, sufficient cellular energy is produced in the form of ATP, which suppresses AMPK activity. Under conditions of low energy, AMPK phosphorylation of TSC2 and Raptor attenuates mTORC1 activity [114-118]. Via an AMP/ADP-independent mechanism the glycolytic intermediate fructose-1,6-bisphosphate (FBP) is sensed by aldolase, which binds to the v-ATPase on the lysosomal surface. In the absence of FBP, interactions between aldolase and the v-ATPase are altered, allowing formation of an AXIN-based AMPK-activation complex containing the v-ATPase, Ragulator, AXIN, LKB1, and AMPK, causing increased Thr172 phosphorylation and AMPK activation $[119,120]$. Thus, aldolase operates as a sensor for glucose availability that directly links glucose shortage to activation of AMPK [119].

Accumulating evidence from other experimental models supports the view that galactose via induction of oxidative stress activates mTORC1 [121-123]. Notably, galactoseinduced overactivation of mTORC1 promotes senescence of neural stem cells and aging of mesenchymal stem cells $[122,124,125]$. The role of oxidative stress on mTORC1 is still a highly debatable subject. Of interest, various lactobacilli used in food and dairy fermentation increase NRF2 activation resulting in NRF2-induced sestrin expression, which attenuates mTORC1 activation [126,127].

Taken together, milk provides a variety of macronutrients that relay the appropriate, species-specific activation of mTORC1 [7]: (1) amino acids that induce growth factor signals (GH; insulin, IGF-1); (2) a well-balanced array of amino acids that communicate with amino acids sensors that activate mTORC1; (3) milk lipids, especially palmitic acid, which activates mTORC1; and (4) lactose and its hydrolysis products glucose and galactose that provide cellular energy and promote mTORC1 activation. This complex endocrine system has been shaped to perfection over millions of years of mammalian evolution [128-130]. As mammals rely on milk for the promotion of postnatal growth, the effectors provided by the lactation genome on the donor site and the milk sensors of the milk recipient have to interact in a synergistic fashion to fulfill milk's biological function: the activation of mTORC1, the primary cell-autonomous nutrient sensor for growth and maturation in mammals [131].

\subsection{Milk Exosomal MicroRNAs}

Pasteurized milk transfers bioavailable milk-derived exosomes (MEX) and their generegulatory microRNAs (miRs) [132-137]. Bovine and human MEX and their miRs resist degradative conditions in the gastrointestinal tract, reach the systemic circulation, and distribute in various tissues [134,138-144]. In fact, increasing evidence presented by studies in humans and animal models supports the view that MEX and their miRs are bioavailable and reach the systemic circulation [134,136,145-147], and modify gene expression of the milk recipient [132,148-150]. MEX miR-mediated changes of epigenetic regulation appear to be beneficial for growth and maturation of the infant [143,151-158], but may exert adverse health effects during long-term exposure associated with persistent overactivation of mTORC1 (Figure 2) [159]. 


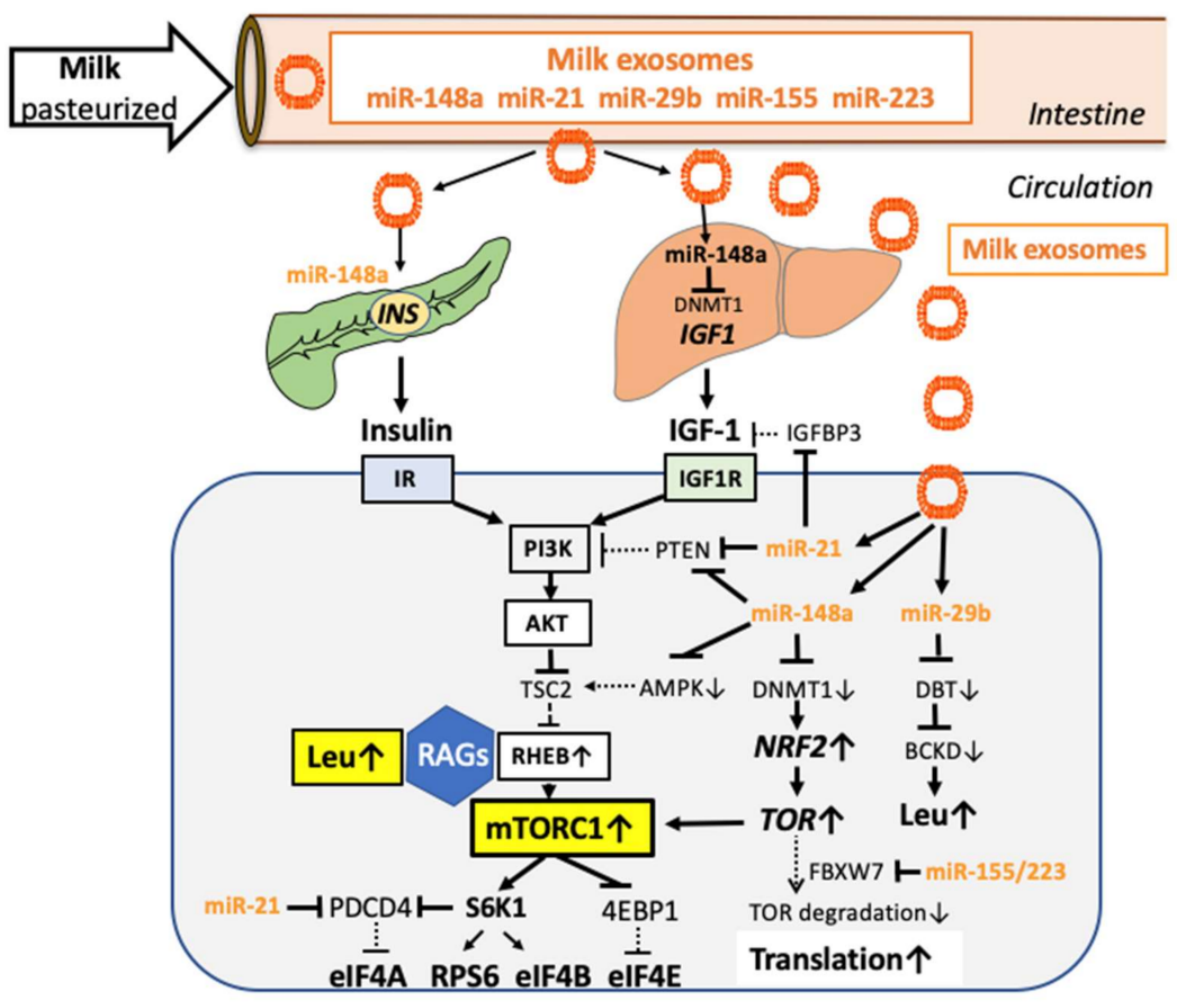

Figure 2. Model of milk miR-mediated epigenetic regulation increasing mTORC1 signaling. Milkderived exosomal miRs enhance insulin/IGF-1/PI3K/AKT signaling, enhance intracellular levels of BCAAs, and promote mTOR expression. Abbreviations: miR: micro-ribonucleic acid; DNMT1: DNA methyltransferase 1; INS: insulin gene; IR: insulin receptor; IGF1: IGF-1 gene; IGF-1: insulin-like growth factor 1; IGFBP3: IGF binding protein 3; IGF1R: IGF-1 receptor; PI3K: phosphoinositide-3kinase; PTEN: phosphatase and tensin homolog; AKT: Akt kinase (protein kinase B); AMPK: AMPactivated protein kinase; TSC2: tuberin; RHEB: ras homolog enriched in brain; Leu: leucine; RAG: ras-related GTP binding protein; mTORC1: mechanistic target of rapapmycin complex 1; PDCD4: programmed cell death 4, S6K1: ribosomal protein S6 kinase 1; 4EBP1: eukaryotic translation initiation factor 4E-binding protein 1; eIF4A: eukaryotic translation initiation factor 4A; RPS6: ribosomal protein S6; eIF4B: eukaryotic translation initiation factor 4B; eIF4E: eukaryotic translation initiation factor 4E; NRF2: nuclear factor erythroid 2-related factor 2; TOR: target of rapamycin; FBXW7: F-box and WD40 domain protein 7; DBT: dihydrolipoamide branched-chain transacylase; BCKD: branched-chain alpha-ketoacid dehydrogenase.

\subsubsection{MiR-148a}

MiR-148a is the most abundant miR in cow milk and MEX [132,160-164] and is highly conserved between mammals [165]. Notably, MIR148A is a domestication gene of dairy cattle increasing milk yield [166,167]. Milk miR-148a nucleotide sequences of humans and dairy cows are identical [132] (mirbase.org, accessed 16 February 2021), allowing miR-based cross-species communication between cattle and human milk consumers [168]. A major target of miR-148a is DNA methyltransferase 1 (DNMT1) [169] resulting in MEX-mediated suppression of DNMT1 expression [132,149], a key mechanism modifying postnatal epigenetic regulation activating mTORC1 signaling [150,153,170,171] Impaired DNMT1-dependend promoter methylation increases the expression of various developmental genes including insulin (INS) [172], IGF-1 (IGF1) [173] and fat mass- and obesity-associated gene (FTO) [174-177], which all promote insulin/IGF-1-PI3K-AKT- and FTO/amino acid-mediated activation of mTORC1 $[178,179]$.

FTO is a N6-methyladenosine (m6A) demethylase, which controls the expression of several components of the mTORC1 pathway [180-183]. Milk via miR-148a-, miR-21- and miR-29b-mediated suppression of DNMTs may promote CpG demethylation at intron 1 of 
FTO increasing FTO expression amplifying the m6A-regulated transcriptional machinery for postnatal growth [184]. DNMT1 inhibition upregulates the expression of nuclear factor erythroid 2-related factor 2 (NRF2) [185], a key transcription factor promoting the expression of mTOR (MTOR) [186]. MiR-148a also attenuates the expression AMP-activated protein kinase (AMPK) via targeting the catalytic subunit $\alpha 1$ of AMPK (PRKAA1) as well as the AMPK regulatory subunit $\gamma 2$ (PRKAG2) [187] (targetscan.org, accessed 16 February 2021). AMPK directly phosphorylates at least two proteins to induce rapid suppression of mTORC1 activity, the TSC2 tumor suppressor, and the critical mTORC1 binding subunit Raptor [104,116]. In addition, miR-148a targets phosphatase and tensin homolog (PTEN) the upstream negative regulator of PI3K [149]. Thus, miR-148a, the most abundant miR of cow milk, epigenetically augments several checkpoints of growth factor- and amino acid signaling pathways that activate mTORC1.

\subsubsection{MiR-21}

Bovine miR-21 is another abundant signature miR of cow milk [160] with nucleotide sequence homology to human miR-21 [188] (mirbase.org, accessed 16 February 2021). By use of RNase H2-dependent PCR, which distinguishes between bovine and human miRs with small variations in the nucleotide sequence, plasma concentrations of Bos taurus (bta)-miR-21-5p was $>100 \%$ higher $6 \mathrm{~h}$ after commercial cow milk consumption of healthy human volunteers than before milk consumption strengthening the bioavailability of milk-derived miRs in human milk consumers [136]. In analogy to miR-148a, miR-21 attenuates the expression of DNMT1 [169], thus modifies epigenetic regulation. Importantly, miR-21 activates mTORC1, promotes growth and anabolism [6], and is regarded as an oncomir promoting sustained cell proliferation and cancer growth [189-197]. In particular, miR-21 inhibits key suppressors of the mTORC1 pathway such as IGF binding protein 3 (IGFBP3) [194], PTEN [189-191], and the inhibitor of translation initiation programmed cell death 4 (PDCD4) [190,192,193].

\subsubsection{MiR-155 and MiR-223}

Further dominant immune-regulatory miRs of bovine milk are miR-155 and miR223 [138,139,163,198,199]. MiR-155 also targets IGFBP3 [200] and PTEN [201]. MiR-155 and miR-223 suppresses mTOR degradation via targeting the expression of F-box and WD40 domain protein 7 (FBXW7) [202] (targetscan.org, accessed 16 February 2021), a key regulatory checkpoint that mediates ubiquitination-dependent degradation of mTOR [203].

\subsubsection{MiR-125b and MiR-30d}

MiR-125b is another important bovine miR in milk, which withstands digestion under simulated gastrointestinal tract conditions $[139,162,199]$. MiR-30d belongs to the top 10 expressed miRs when parsing the sequence data, based on different species (buffalo, cow, pig, human, and panda milks) $[132,147,204,205]$. Notably, both miR-125b and miR-30d inhibit the expression of TP53, the guardian of the genome [206-208]. Recent evidence indicates that bovine MEX transfected with fluorophore (IRDye)-labeled miR-30d and miR21 accumulated in murine placenta and embryos of C57BL/6 mice after oral gavage [209]. In accordance, MEX-associated and free human miR-30d was internalized by mouse embryos via the trophectoderm, resulting in an indirect overexpression of genes encoding for certain molecules involved in murine embryonic adhesion [210]. MEX miR-125b and miR-30d via targeting TP53 may represent another key mechanism of milk modifying mTORC1 signaling [211].

In particular, p53 induces the expression of a group of p53 target genes in the IGF$1 / \mathrm{AKT}$ and $\mathrm{mTORC} 1$ pathways, and all of these gene products negatively regulate the IGF-1/AKT and mTORC1 pathways in response to stress signals. They are IGFBP3 [212], PTEN [213-216], TSC2 [213], AMPK $\beta 1$ [213], Sestrin1, and Sestrin2 [217]. With the exception of Sestrin2, which via leucine sensing also activates mTORC1 [218] and via 
AMPK activation that inhibits mTORC1 $[217,219]$, all other p53 targets increase mTORC1 signaling [211].

\subsection{5. $\mathrm{MiR}-29 \mathrm{~b}$}

MiR-29b is another important miR of commercial cow milk, which survives pasteurization and storage [133]. Bovine MEX miR-29b is taken up by intestinal epithelial cells via endocytosis [220]. After consumption of $0.25,0.5$, and $1.0 \mathrm{~L}$ of commercial milk, respectively, plasma levels of miR-29b increased after $6 \mathrm{~h}$ in a dose-dependent manner and modified blood monocyte gene expression [148]. In synergy with the DNA methylationsuppressing effects of miR-148a and miR-21, miR-29b also attenuates the expression of DNMT3A/B [221-224]. Thus, signature miRs of milk shape the epigenome and enhance the expression of developmental genes that increase mTORC1 signaling [153,170,171,184].

MiR-29b attenuates BCAA catabolism via targeting the mRNA for the dihydrolipoamide branched-chain transacylase (DBT), the E2-core subunit of branched-chain $\alpha$-ketoacid dehydrogenase (BCKD) increasing cellular BCAA levels [225]. BCKD activity is regulated through the action of the complex-specific BCKD kinase that phosphorylates two serine residues in the E1 $\alpha$ subunit and thereby inhibits BCKD. Notably, insulin stimulates BCKD kinase expression inhibiting BCKD increasing cellular BCAA levels [226-231]. Mechanistically, MEX miR-29b functions as an enhancer of insulin-mediated suppression of BCAA catabolism promoting mTORC1 activation at both the PI3K/AKT/TSC2/RHEB and the BCAA/RAG-Ragulator/RHEB pathway.

\section{Milk-Induced Overactivation of mTORC1 and Diseases of Civilization}

The impact of cow's milk consumption in Western countries already begins during pregnancy, affecting the fetal growth period, accompanying the infant and childhood growth period, puberty, adulthood, and higher ages. Epidemiological and translational evidence will be presented that milk-induced overactivation of insulin/IGF-1 signaling combined with extensive supply of dairy-derived essential amino acids and milk-derived miRs overstimulates mTORC,1 promoting Western diseases of civilization [232,233].

\subsection{Fetal Growth and Birthweight}

The Danish National Birth Cohort shows an association between maternal milk consumption and birthweight [234], subsequently confirmed by further systematic reviews [235-238]. Increased trophoblast mTORC1 activity determines placental-fetal transfer of amino acids and glucose and thus fetal growth and birthweight [239-244]. Recent evidence underlines that mTORC1 signaling regulates the expression of trophoblast genes involved in ribosome and protein synthesis, mitochondrial function, lipid metabolism, nutrient transport, and angiogenesis, representing novel links between mTOR signaling and multiple placental functions critical for fetal growth and development [245]. Not only milk-derived BCAAs, but also bovine MEX and their miR cargo, delivered by oral gavage, reach the murine placenta [209]. Of note, fluorophore-labeled MEX, miR-21-5p, and miR$30 \mathrm{~d}$ accumulate in murine placenta and embryos following oral MEX administration [209]. Remarkably, the size of litters born to dams fed a MEX- and RNA-depleted diet was $25-50 \%$ smaller than those born to MEX- and RNA-sufficient controls [209], pointing to a significant gene-regulatory contribution of MEX miRs for fetal growth. It is assumed that $60 \%$ of genes and their expression is regulated by miRs. In fact, increased human placental miR-21 levels correlate with the risk of fetal macrosomia [246,247]. Remarkably, cow's milk consumption by humans during pregnancy, but not the intake of fermented milk products, increase birthweight $[234,235]$, which underlines the mTORC1-activating and growth promoting effects of MEX. Thus, high milk consumption during pregnancy promotes mTORC1-driven fetal overgrowth [248]. In accordance, cafeteria and high-fat diets in nursing rats and mice modifies specific miR levels in milk [249,250]. Cow's milk consumption during the lactation period may as well change the composition of milk miRs promoting postnatal growth. 


\subsection{Menarche, Height, Body Mass Index}

The National Health and Nutrition Examination Survey (NHANES) [251] and the Tehran Lipid and Glucose Study $[252,253]$ report an association between cow's milk consumption and early menarche, a risk factor of breast cancer (BC) [254], which correlates to breast density [255]. NHANES also demonstrates an association between cow's milk consumption and linear growth $[42,256]$, well explainable by the increased somatotropic axis (GH/IGF-1) due to milk consumption [20,43,257]. NHANES also reports a milk-dependent increase of body mass index (BMI), predominantly in infants 2-4 years of age [258]. The increase of growth parameters and BMI by milk consumption points to an overactivation of mTORC1 by milk consumption, which is not observed with the consumption of fermented milk products $[252,256]$.

\subsection{Acne Vulgaris}

Increased height and BMI during puberty correlates with a higher incidence of acne vulgaris [259-262], the most common inflammatory skin disease in industrialized countries, pointing to common accelerated growth trajectories in acne pathogenesis. The relationship between cow milk consumption and acne has been confirmed by recent meta-analyses [263-265]. In contrast, lactose-intolerant individuals, who generally avoid milk, exhibit a $50 \%$ lower frequency of acne compared to lactose-tolerant people [266]. Of concern, more severe acne during adolescence correlates with a higher risk of prostate cancer (PCa) and BC [267-270].

Acne is an IGF-1- and androgen-dependent disease of human sebaceous glands associated with sebaceous gland hyperplasia, increased and disturbed sebaceous lipogenesis, and enhanced proliferation of acro-infundibular keratinocytes (comedogenesis) [271,272]. Acne represents the prototype of an mTORC1-driven skin disease [273-276]. In fact, pathologically increased mTORC1 activity has been measured in epidermis and sebaceous glands of acne patients [277-280]. Thus, acne is regarded as the mTORC1-driven metabolic syndrome of the pilosebaceous follicle [281]. In accordance with states of overactivated mTORC1/S6K1 signaling, acne is often associated with insulin resistance [282-285]. A potential explanation is mTORC1-mediated overactivation of the kinase S6K1 [277], which via inhibitory phosphorylation of insulin receptor substrate 1 (IRS-1) attenuates insulin signaling [286-289].

\subsection{Diabetes Mellitus Type 2}

Insulin resistance has been observed in children after high consumption of milk compared to meat intake [290]. The first meta-analysis, which investigated the effects of milk versus fermented milk and their relation to diabetes mellitus type 2 (DMT2), is the European Prospective Investigation into Cancer and Nutrition (EPIC) [291]. EPIC shows an increased risk of DMT2 by milk consumption in five out of eight European countries including Germany [291]. The Framingham Heart Study Offspring Cohort [292] and the Physicians' Health Study [293] confirm an association between milk consumption and prediabetes as well as DMT2. The Dutch Lifeline Cohort Study exhibits a positive association between whole milk intake $(150 \mathrm{~g} /$ day $)$ and prediabetes as well as a relation between milk consumption (150 g/day), especially skim milk (150 g/day) and DMT2 [294]. Increased $\beta$-cell mTORC1 activity plays a critical role in the pathogenesis of DMT2 [295-302], which is normalized by the AMPK activator and mTORC1 inhibitor metformin [303-305]. Recent evidence underlines that the ratio mTORC1/AMPK is increased in DMT2 [301]. Pancreatic $\beta$-cells differentiate during fetal life, but only postnatally acquire the capacity for glucose-stimulated insulin secretion (GSIS) [301]. An increased responsiveness to dietary glucose is required at the end of the breastfeeding period, which delivers a nearly constant supply of lactose. The dramatic change during weaning is associated with a switch of increased mTORC1 activity to enhanced AMPK activity. While mTORC1 signaling stimulates $\beta$-cell proliferation, AMPK signaling promotes $\beta$-cell mitochondrial biogenesis, a shift to oxidative metabolism, and functional maturation of $\beta$-cells [301]. In fact, increased plasma levels of miR-148a have been associated with T2DM progres- 
sion, increased $\mathrm{HbA1c}$, HOMA-IR, and hyperinsulinemia [306]. It has been hypothesized that MEX miR-148a, which inhibits AMPK, maintains the hyperactivated state of $\beta$-cell mTORC1 activity during the period of breastfeeding (milk intake), a meaningful mechanism during the breastfeeding period, but a detrimental effect for $\beta$-cell homeostasis in the long-run [302].

\subsection{Prostate Cancer}

The Physicians' Health Study identified the consumption of whole milk as a risk factor of prostate cancer (PCa) [293]. The meta-analysis of Lu et al. [307] confirmed a dose-dependent correlation between milk consumption and PCa mortality. The Reykjavik Study showed that daily milk consumption during the first 20 years of life compared to non-daily milk intake increased the risk of advanced PCa by the factor of 3.2 [308]. In analogy to acne [276-281], increased IGF-1/PI3K/AKT/mTORC1 signaling plays a key role in prostate morphogenesis and cancerogenesis [309-314]. S-adenosylmethionine decarboxylase 1 (AMD1) is upregulated in human PCa dependent on activated mTORC1 [315]. In PCa tissue, mTORC1 integrates and translates growth signals into an oncogenic metabolic program [311-316]. Notably, the activity of the lipogenic transcription factor SREBF1, which is important for PCa cell growth, is regulated by androgen receptor (AR)/mTOR nuclear axis in PCa [317]. Increased recurrence rates and more aggressive courses correlate to the consumption of whole milk, but not fermented milk products [318,319].

Data from molecular pathology support the involvement of miR-148a, miR-125b, and miR-21 in PCa initiation and progression. MiR-148a is upregulated in serum and PCa tissue of men with PCa associated with an increase in Gleason score [320]. MiR-148a is an androgen-responsive miR that promotes LNCaP prostate cell growth by repressing its target cullin-associated and neddylation-dissociated 1 (CAND1). CAND1 is a negative regulator of SKP1-Cullin1-F-box (SCF) ubiquitin ligases by binding to the $3^{\prime}$-untranslated region of CAND1 mRNA [321], thereby increasing cellular levels of cyclin E [322]. Interestingly, cyclin-dependent kinase inhibitor 1B (CDKN1B) loss is an important initiator of PCa [323]. MiR-148a silences CDKN1B, which is consistent with the increase in proliferation through increased S-phase transition observed after miR-148a transfection into LNCaP cells [324]. In addition, miR-148a inhibits DNMT1 [132,149,169], which enhances AR expression via the repressive E2F1/DNMT1 axis [325]. Furthermore, miR-148a promotes DNMT1-dependent epithelial-mesenchymal transition (EMT) and the progression of PCa stem cells [326]. MiR148a-mediated suppression of AMPK, which increases mTORC1 activation [104,105], appears to be the rationale for the treatment and prevention of PCa with AMPK agonists/mTORC1 antagonists [303,327,328].

MiR-125b plays an emerging role in several cancers [329] and is an androgen-induced miR that is overexpressed in PCa [330,331]. MiR-125b promotes growth of PCa xenograft tumor through targeting proapoptotic genes including p53, PUMA, and BAK1 [332]. MiR-125b targets p14 affecting p14(ARF)/MDM2 resulting in enhanced p53 catabolism with proliferation of PCa cells [333]. MiR-125b is involved in regulating NF- $\mathrm{B}, \mathrm{p} 53$, $\mathrm{PI} 3 \mathrm{~K} / \mathrm{AKT} / \mathrm{mTORC1}$, ERBB2, WNT, and other signaling pathways, thereby controlling cell proliferation, differentiation, metabolism, apoptosis, drug resistance, and tumor immunity. MiR-21 is another oncogenic miR overexpressed in PCa that inhibits various tumor suppressor genes such as PTEN enhancing mTORC1 activation [334-344].

Thus, MEX-derived circulatory miRs that may reach the prostate and target critical tumor suppressor genes enhance the activity of mTORC1 [207,312].

\subsection{Breast Cancer}

The Norwegian Cancer Registry showed that daily intake of $>750 \mathrm{~mL}$ whole milk compared to $<150 \mathrm{~mL}$ daily milk intake enhanced the risk of BC by the factor of 2.91 [345]. McCann et al. [346] observed positive associations between milk intake and risk of estrogen receptor (ER)-negative BC (OR: 1.58; 95\% CI: 1.05, 2.37). Frazer et al. [347] reported an increase in $\mathrm{BC}$ risk $(\mathrm{HR}=1.50 ; 95 \% \mathrm{CI}$ : $1.22-1.84)$ related to milk consumption independent 
of milk fat content in a Californian cohort. A stronger association was found in ER+ and progesterone receptor-positive $(\mathrm{PR}+)$ tumors. Already the daily intake of $158 \mathrm{~mL}$ milk enhanced $\mathrm{BC}$ risk, whereas the consumption of cheese and yogurt had no negative effects. Kaluza et al. [348] recently confirmed, that high and continuous consumption of two daily servings of non-fermented milk compared to no milk consumption, increased the incidence of $\mathrm{ER}+/ \mathrm{PR}+\mathrm{BCs}(\mathrm{HR}=1.30 ; 95 \% \mathrm{CI}$ : 1.02-1.65). Especially women with normal weight $\left(\mathrm{BMI}<25 \mathrm{~kg} / \mathrm{m}^{2}\right)$ exhibited an increased $\mathrm{BC}$ risk (HR $\left.=1.55 ; 95 \% \mathrm{CI}: 1.08-2.21\right)$. In contrast, the consumption of fermented milk products showed an inverse incidence in ER/PR-cancers [193]. A Chinese study identified high milk consumption as a BC risk factor in women of rural regions [349]. Further controlled case studies show that milk consumption increases BC risk [350,351], whereas lactose intolerance reduces BC risk [352].

Early menarche, elevated IGF-1 serum levels, increased breast density, and accelerated breast growth during adolescence are well-known risk factors of BC [353-359]. The intake of sugar-based milk drinks (>125 g/day) increased fibroglandular volume in girls [360]. IGF-1 and estrogens, which are increased in milk of persistently pregnant dairy cows [361], have a synergistic effect in mammary cancerogenesis [362,363].

Essential PI3K/mTORC1 signaling pathway activation has been observed in most BCs [364-369]. Mutations in the PI3K/AKT/mTOR pathway are frequently found in $\mathrm{BC}$ and associated with cellular transformation, tumorigenesis, cancer progression, and drug resistance [365-369]. In particular, hyperactivation of the PI3K/AKT/mTORC1 is implicated in the tumorigenesis of ER+ BC and in resistance to endocrine therapy [364,368,369]. Metformin in a diabetes-independent manner significantly reduces BC risk, compared to patients who are not using metformin [370]. Kelch-like 22 (KLHL22) is a broad complex, tramtrack, and bric-a-brac (BTB) adaptor protein, which forms a functional cullin-RING E3 ubiquitin ligase complex with the scaffold protein CUL3 and the ring finger protein RBX1, is upregulated in BCs. Independent of PI3K/AKT signaling, KLHL22 activates amino acid-dependent mTORC1 signaling to promote tumorigenesis [371].

Importantly, mTORC1 emerged as a critical node in estrogenic signaling in BC cells. Estrogen rapidly and potently activates mTORC1 signaling. In addition, mTORC1 is a crucial activator of ER $\alpha$ transcriptional activity [372]. ER $\alpha$ binds to Raptor and causes it to translocate to the nucleus upon estrogen stimulation. In addition, nuclear mTOR kinase phosphorylates $\mathrm{ER} \alpha$ on S104/106 and thereby activates transcription of ER target genes [373]. Upon mitogen and estrogen stimulation, S6K1 and mTORC1, respectively, are able to phosphorylate $\mathrm{ER} \alpha$, significantly affecting chromatin binding and transcriptional activity in a ligand independent fashion [373-376], while establishing a feed-forward mechanism that may drive cancer progression through upregulation of eIF3 by ER $\alpha[377,378]$.

Of note, the biological effects of estrogens are mainly mediated by the activation of $\mathrm{ER} \alpha$, whose activity is deeply influenced by the insulin/IGF-I signaling pathway [379,380]. In fact, IGF-1-mediated activation of S6K1 promotes ER $\alpha$ (S167) phosphorylation affecting the transcription of ER $\alpha$-regulated genes [381]. Thus, increased insulin/IGF-1 signaling by consumption of commercial milk increases $\mathrm{ER} \alpha$-induced gene expression. There is recent evidence that $\mathrm{ER} \alpha$ signaling is also upregulated by miRs [382], especially miR148a [383], which functions as an oncogene of tumor suppressor depending on the cancer type [384]. miRNA-148a targets DNMT1, which suppresses the expression of ER- $\alpha$ via DNA methylation [383]. Indeed, miRNA-148a regulates ER- $\alpha$ expression through DNMT1mediated DNA methylation in BC cells, whereas miRNA-148a inhibition decreases ER $\alpha$ expression [383]. ER $\alpha$ enhances the expression of L-type amino acid transporter 1 (LAT1, SLC7A2 [385-387], which increases cellular leucine influx activating mTORC1 [73-84]. In fact, increased expression of LAT1 has been reported in BC [388,389], preferentially in chemoresistant BC [390]. Of note, proliferation-related genes are highly expressed in a subgroup of patients with high SLC7A5/SLC3A2, and knockdown of SLC7A5/SLC3A2 decreased proliferation of ER+ BC cells [391]. Saito et al. [392] found that scribble cell polarity complex component 2 (LLGL) regulates proliferation of ER+ BC cells in culture and in vivo under leucine stress conditions by promoting uptake of leucine. LLGL2 interacts 
with SLC7A5 by forming a trimeric complex with SLC7A5 and a regulator of membrane fusion, YKT6, to promote leucine uptake and cell proliferation [392].

MiR-21, a component of bovine MEX [209,393], is overexpressed in BC compared with normal breast tissue and has been associated with advanced stage, lymph node positivity, and reduced survival time [394-396]. Of note, increased levels of circulating miR-21 in plasma and plasma exosomes has been reported in BC patients [397-399].

In accordance with miR-21, both plasma and tissue expression of miR-155 increased in BC patients compared to controls [400]. Importantly, miR-155-enriched exosomes accelerate EMT of BC cells [401]. Interestingly, functional BRCA1 inhibits the expression of oncogenic miR-155 [402,403]. Individuals with BRCA1 loss-of-function mutations are thus exposed to higher oncogenic signaling of miR-155, which may be further aggravated by the uptake of MEX-derived miR-155.

Remarkably, increased miR-155 expression in the ER $\alpha+B C$ cells results in a repression of RICTOR enhancing activation of mTORC1 signaling [404]. Furthermore, FBXW7, which promotes mTOR degradation [203,405], is less expressed in BC tissues and cell lines, and is an independent positive factor for the overall survival rate of patients with BC $[406,407]$. MiR-155 and miR-223, abundant components of cow milk [138,139,163,198,199,203], both target FBXW7 and thus increase mTORC1 signaling [202,408,409].

Taken together milk-derived miRs may enhance mTORC1 signaling in BC cells at various checkpoints of the mTORC1 signaling cascade.

\subsection{Hepatocellular Carcinoma}

EPIC demonstrated an association of increased risk of hepatocellular carcinoma (HCC) with the consumption of milk ( $\mathrm{HR}=1.51 ; 95 \% \mathrm{CI}: 1.02-2.24)$, but not yogurt ( $\mathrm{HR}=0.94$, 95\% CI: 0.65-1.35) [410]. The Health Professionals Follow-Up Study and Nurses' Health Study confirmed an increased risk of HCC with milk consumption (HR $=1.23 ; 95 \% \mathrm{CI}$ : $0.83-1.83$ ), especially skim milk ( $\mathrm{HR}=1.36$; $95 \%$ CI: $0.91-2.03)$, but not yogurt $(\mathrm{HR}=0.72$; 95\% CI: 0.49-1.05) [411]. The Guangzhou Biobank Cohort Study showed that moderate milk intake (250-750 mL/week) compared with higher milk consumption ( $>750 \mathrm{~mL} /$ week) was associated with an increase of all cancer mortality and enhanced HCC mortality from 3.8 to 7.0 per 10,000 person years [412].

In HCC tissue, mTORC1 is highly activated [413-416]. Loss of BCAA catabolism during carcinogenesis enhances mTORC1 activity and promotes tumor development and progression [414,415]. MEX-derived miR-29b via targeting BCKD [225], may promote HCC [417]. As shown in mice after oral administration of bovine MEX, MEX and miR-21 accumulate in the liver and other tissues [134,209]. Plasma exosomal miR-21 and miR-155 are oncogenic miRs promoting mTORC1-driven hepatocancerogenesis [417-423]. Thus, upregulated mTORC1 via milk-derived BCAAs and oncogenic MEX-derived miRs may explain the increased risk of HCC by milk consumption [417].

\subsection{Diffuse Large B-Cell Lymphoma}

According to a large meta-analysis [424], a positive association has been reported for milk consumption and non-Hodgkin's lymphoma (NHL) $(\mathrm{RR}=1.41 ; 95 \% \mathrm{CI}: 1.08-1.84)$, whereas a reduced risk was observed for yogurt consumption ( $\mathrm{RR}=0.78 ; 95 \% \mathrm{CI}: 0.54-1.12$ ). Each $200 \mathrm{~g}$ of daily milk intake increased the risk of NHL by 6\% [424]. After NHL subtype differentiation, a significant association was found between milk intake and diffuse large B-cell lymphoma (DLBCL) $(\mathrm{RR}=1.49 ; 95 \% \mathrm{CI}: 1.08-2.06)$. DLBCL is the most common type of lymphoma, representing approximately one-third of all cases worldwide [425].

In DLBCL, mTORC1 signaling is upregulated $[426,427]$ and is therapeutically attenuated by the mTORC1 inhibitor everolimus [427]. MiR-21 as well as miR-155 promote the proliferation of malignant B-lymphocytes [428-435]. Of note, miR-21 plays an oncogenic role by targeting FOXO1 and activating the PI3K/AKT pathway in DLBCL [429]. Overexpression of plasma miR-155 was significantly upregulated in patients with DLBCL compared to healthy individuals and was related to a shorter overall survival time [436]. B- 
cell lymphoma cells showed a higher expression of miR-155 and a low expression of FOXO3 than B-lymphocytes [437]. FOXO3-mediated expression of sestrin 3 activates AMPK [438], which via TSC2 phosphorylation inhibits mTORC1 [439]. Reduced FOXO1 and FOXO3 expression via overexpression of miR-21 and miR-155, respectively, thus increase mTORC1 signaling in DLBCL lymphocytes.

\subsection{Parkinson's Disease}

The Greek EPIC cohort showed a significant correlation between milk consumption and Parkinson's disease (PD) $(\mathrm{HR}=1.34$; 95\% CI: 1.14-1.58), whereas cheese and yogurt consumption showed no association [440]. A large meta-analysis of prospective cohort studies identified an increased risk for PD by milk consumption $(\mathrm{RR}=1.45$; 95\% CI: $1.23-1.73)$, cheese $(\mathrm{RR}=1.26$; 95\% CI: 0.99-1.60), but not yogurt $(\mathrm{RR}=0.95$; 95\% CI: 0.76-1.20) [441]. The Nurses' Health Study and the Health Professionals Follow-up Study confirmed an increased risk of PD with consumption of low-fat milk (HR = 1.39; 95\% CI: 1.12-1.73) and milk of all fat levels (HR = 1.56; 95\% CI: 1.30-1.88) [442]. Olsson et al. [443] studied the influence of milk versus fermented milk in Swedish PD patients. Compared to no or low milk intake ( $<40 \mathrm{~mL} /$ day), milk consumption of 40-159 mL/day showed a HR = 1.29 (95\% CI: 1.07-1.56), 160-200 mL/day a HR = 1.19 (95\% CI: 0.99-1.42), 201-400 mL/day a HR = 1.29 (95\% CI: 1.08-1.53), and over $400 \mathrm{~mL} /$ day a HR = 1.14 (95\% CI: 0.93-1.40). Fermented milk was not associated with PD risk [443].

The hypothesis that contamination of milk with neurotoxic compounds is causal for milk's PD-inducing effects [444] has recently been challenged [445]. There is accumulating evidence that milk's intrinsic mTORC1-activating signaling capacity promotes the pathogenesis of PD [445]. PD is an $\alpha$-synucleinopathy associated with mitochondrial dysfunction, oxidative stress, deficient lysosomal clearance of $\alpha$-synuclein ( $\alpha$-syn), and aggregation of misfolded $\alpha$-syn [446-448]. Increasing evidence substantiates that imbalances of mTORC1 and autophagy are critically involved in the pathogenesis of PD [449-452]. Enteroendocrine cells, which are able to synthesize $\alpha$-syn and exhibit vagal nerve connectivity to the brain, are in the recent focus in PD pathogenesis [453-459]. In contrast to milk consumption, increased intake of caffeine and green tea polyphenols and smoking have been associated with a decreased risk of PD [460]. Remarkably, caffeine, epigallocatechin-3-gallate, and nicotine are inhibitors of mTORC1 activating autophagy [461-466]. Milk via activation of mTORC1 may inhibits ULK-1, the key mediator of mTORC1 signaling to autophagy, that regulates early stages of autophagosome formation in response to starvation or mTORC1 inhibition [467].

Notably, hypomethylation of the SNCA promoter increases $\alpha$-syn expression, which is controlled by DNMT1 [468-472]. Intriguingly, the neurotoxic compound 1-methyl4-phenyl-1,2,3,6-tetrahydropyridine (MPTP), which is used in murine models for the induction of PD, increases the expression of miR-148a associated with downregulation of DNMT1 in substantia nigra of MPTP-treated mice [473]. It is conceivable, that MEX miR-148a targets DNMT1 expression of enteroendocrine cells increasing the expression of $\alpha$-syn [445]. Moreover, AMPK-induced autophagy may be further attenuated by MEX miR148a. It has been demonstrated that the upregulation of miR-148a inhibits the expression of AMPK [187], resulting in increased mTORC1 activity [104] and attenuated ULK1-mediated autophagy [474-476].

In addition, increased expression of miR-21 has been reported in substantia nigra of PD patients associated with decreased expression of lysosome-associated membrane protein type 2A (LAMP2A), which is a direct target of miR-21 [477,478]. LAMP2A plays a key role in chaperone-mediated autophagy (CMA), which is disturbed in PD [468,478].

Thus, milk signaling via MEX-derived miRs may overactivate mTORC1 and decrease autophagy resulting in overexpression of $\alpha$-syn and impaired degradation of aggregated neurotoxic $\alpha$-syn promoting the pathogenesis of PD. 


\subsection{Alzheimer's Disease}

Epidemiological studies on milk consumption and Alzheimer's disease (AD) and cognitive decline are contradictory. According to a systematic review and meta-analysis, Lee et al. [479] concluded that the existing evidence is too poor to draw a firm conclusion regarding the effect of milk or dairy intake on the risk of cognitive decline or disorders in adults. However, Kesse-Guyot et al. [480] reported that milk intake but not total dairy was negatively associated with verbal memory performance. Furthermore, Petruski-Ivleva et al. [481] have studied 13,751 participants of the Atherosclerosis Risk in Communities (ARIC) cohort and performed three neurocognitive evaluations from 1990 through 2013. They observed that milk intake greater than 1 glass/day was associated with greater decline in cognitive functions over a 20-year observation period. Despite the scarcity of evidence on this topic, the latest systematic review on milk and dairy intake points to a cognitive decline associated with milk consumption [482].

$\mathrm{AD}$ is now the most common form of neurodegenerative dementia in the United States and other Western countries [483]. Subsequent progressive changes in cognition and behavior accompany the later stages of AD. Changes in amyloid precursor protein (APP) cleavage and production of the APP fragment $\beta$-amyloid (A $\beta)$, along with hyperphosphorylated tau protein aggregation coalesce to cause reduction in synaptic strength, synaptic loss, and neurodegeneration $[484,485]$. AD is characterized by the presence of two aberrant structures: namely senile plaques, composed of amyloid- $\beta$ peptide $(\mathrm{A} \beta)$, and neurofibrillary tangles, composed of tau protein [486,487]. AD thus belongs to the group of tauopathies associated with accumulation of abnormal tau protein in the brain [486-489]. Phosphorylation of different tau sites during progression of AD been reported [490]. Substantial evidence indicates that mTORC1 is involved in the formation, secretion, and degradation of toxic phospho-tau [491-494]. The hyperphosphorylation of tau protein and the overexpression of $\mathrm{mTORC} 1$ are considered the driving force behind $\mathrm{A} \beta$ plaques and neurofibrillary tangles, hallmarks of AD [495]. Norambuena et al. [496] reported a crosstalk between mitochondria and lysosomes and identified a role for lysosomal mTORC1 in the nutrient-induced activation of mitochondria. This lysosomal signaling pathway is strongly inhibited by oligomeric $A \beta$ through the tau-dependent activation of plasma membrane-localized mTORC1. Together, these results identify a further role for tau in mediating A $\beta$ toxicity [497]. A number of mTORC1-dependent and independent autophagy modulators have been identified to have positive effects in AD treatment [498,499]. Recent evidence indicates that mTORC1 inhibition and autophagy activity are directly linked to tau clearance [500]. In contrast to neuronal mTORC1 signaling, microglial deficiency of TREM2, a surface receptor required for microglial responses to neurodegeneration, including proliferation, survival, clustering, and phagocytosis, has been associated with impaired mTORC1 activity and anomalous autophagy [501].

The microtubule-associated protein tau (MAPT) has been identified in several intraneuronal compartments, including in association with synapses [502,503]. Tau is a microtubule-associated protein that has a role in stabilizing neuronal microtubules and promotes axonal outgrowth. Structurally, tau is a natively unfolded protein, is highly soluble and shows little tendency for aggregation [504]. In analogy with the epigenetic regulation of the SNCA promoter in PD, increased tau expression is induced by decreased MAPT promoter methylation $[505,506]$. It has been demonstrated that DNMT1 is an epigenetic regulator of MAPT expression [507]. In contrast, hypermethylation of the MAPT gene is neuroprotective by reducing MAPT expression [508].

During the breastfeeding period with physiological transfer of MEX and MEX-derived miR-148a and miR-21 to neuronal cells, miR-148a/miR21-mediated DNMT1 suppression may enhance overall SNCA and MAPT expression for postnatal maturation of synapses promoting synaptic connectivity, in accordance with observed improvements of cognitive functions in mice receiving a MEX-sufficient diet compared to a MEX-deficient diet [509]. Beneficial effects of breastfeeding and cow milk-mediated epigenetic regulation in early life 
may thus turn into adverse effects when milk signaling is not discontinued, as originally programmed by mammalian physiology.

Dysfunction of cell bioenergetics is a common feature of neurodegenerative diseases, the most common of which is AD [510,511] promoting synaptic transmission failure [512]. Oxidative stress is a key driver promoting dysfunction of mitochondria, which are vulnerable to oxidative stress [513-515]. D-Galactose, the hydrolysis product of the milk sugar lactose, is a well-known mitochondrial stressor experimentally used for the induction of brain aging and neurodegeneration [124,516-526]. In humans, hepatic galactose clearance declines with age [519-521]. Notably, galactose induces oxidative stress activating mTORC1 [124] and increases the expression of miR-21 [522].

MiR-148a targets PPARGC1A (peroxisome proliferator-activated receptor- $\gamma$ coactivator$1 \alpha$, PGC-1 $\alpha$ ) [523] (targetscan.org, accessed on 16 February 2021), which is a key transcriptional regulator in tissues that undergo extensive oxidative metabolism and operates as a central organizer of metabolic function, oxidative states, and mitochondrial biogenesis and function [524]. PGC-1 $\alpha$ cooperates with estrogen-related receptor- $\alpha(E R R \alpha)$ in the regulation of mitochondrial biogenesis [525] and plays a central role in the regulation of autophagy [526].

Taken together, persistent milk signaling apparently stimulates overexpression of tau proteins as well as mTORC1-mediated tau phosphorylation promoting the formation of neurofibrillary tangles, enhances galactose-mediated oxidative stress as well as miR-148amediated mitochondrial dysfunction and impaired autophagy, all pathological hallmarks of AD.

\section{Fermentation, All-Cause Mortality, and Aging}

Four epidemiological studies from Sweden, a country with high per capita milk consumption of pasteurized fresh milk, underline an increased dose-dependent risk of all-cause mortality with the consumption of milk [527-531], but not fermented milk/milk products [528,531,532].

Since the Neolithic revolution, the great majority of milk was consumed as fermented milk and fermented milk products [533-535]. However, an unnoticed dramatic change occurred with the introduction of pasteurization and refrigeration of milk, which preserved milk's bioactive exosomal miRs [132-135], allowing them to enter the human food chain in large-scale $[170,171]$. Pasteurization thus preserves milk's bioactive mTORC1 activators including galactose, essential amino acids, and exosomal miRs [132,135,145,160,198,527], whereas fermentation degrades galactose [536-539], essential branched-chain amino acids [540,541], MEX and their miRs, respectively [393]. Whereas addition of milk to a meal increases postprandial insulin levels [542], addition of yogurt reduces postprandial insulinemia [53], thus reduces insulin-mediated mTORC1 signaling. Further information on the impact of fermentation versus pasteurization of milk has been presented elsewhere [9].

Notably, recent evidence underlines that mTORC1 activates the expression of RNA polymerase III ( $\mathrm{Pol}$ III), which limits longevity [543]. Increased mTORC1 signaling shortens lifespan and accelerates aging-related processes such as cellular senescence and stem cell exhaustion [544-555]. Thus, persistent overactivation of mTORC1 by continued cow milk consumption accelerates aging and overall mortality of mTORC1-driven diseases of civilization (Figure 3). 
Milk-mediated mTORC1 signaling

Physiological breastmilk-driven mTORC1 activity
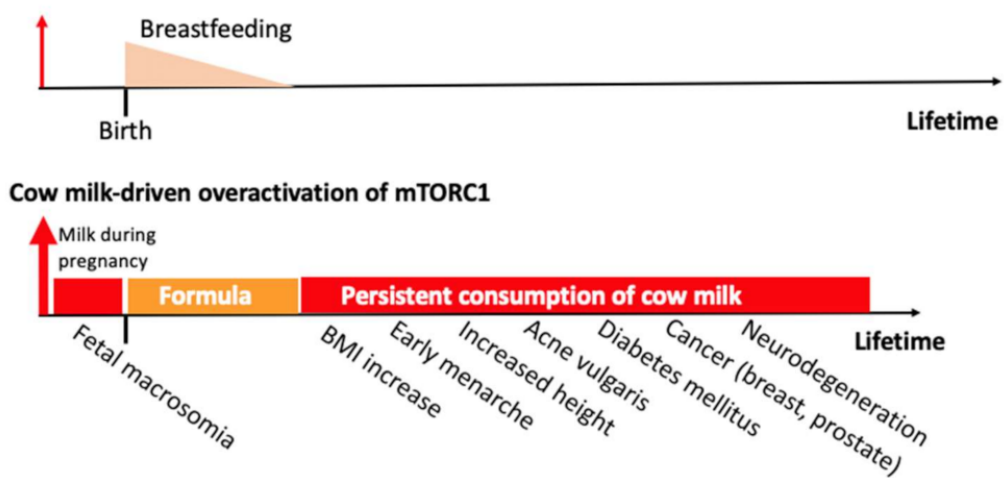

Figure 3. Milk-mediated mTORC1 signaling. Upper panel: physiological milk signaling exclusively only during the postnatal breastfeeding period with milk derived from the biological mother (human lactation genome). Lower panel: cow milk-driven overactivation of mTORC1 begins with maternal cow milk consumption during pregnancy, continues with high protein cow milk-based artificial formula, and continues with milk consumption during all age periods of human life. Persistent milk signaling with overactivated mTORC1 modifies growth trajectories during childhood and adolescence and promotes diseases of civilization.

\section{Conclusions}

Milk, the secretory product of mammary glands, executes the species-specific genetic program of the lactation genome. Milk should not be regarded as a "simple food", but it instead represents the signaling interface between the maternal lactation genome and the infant's cellular mTORC1 system orchestrating growth, anabolisms, metabolic, immunological, and neurological programming [6]. Milk is the exclusive nutrient and nutrigenetic offer for newborn mammals sufficient and well adapted to promote adequate mTORC1-dependent postnatal growth [7]. Obviously, milk presents the masterpiece of mammalian evolution to assist for extrauterine growth, optimized during millions of years of lactation evolution [128]. Thereby, milk relays sophisticated maternal signals for mTORC1 activation to the milk receiver. Milk's amino acids directly activate mTORC1 via the Rag-Ragulator pathway. Whey- and casein-derived amino acids promote insulin and IGF-1 secretion, respectively, increasing PI3K-AKT-mediated activation of mTORC1. Milk amino acid-mediated activation of mTORC1 is supported by a complex network of exosomal miRs that epigenetically enhance mTORC1 signaling [153].

With the introduction of pasteurization $\left(72{ }^{\circ} \mathrm{C}, 15 \mathrm{~s}\right)$ combined with refrigeration, the human milk consumer got exposed to bioactive MEX miRs augmenting milk's mTORC1 activity compared to boiled, ultra-heat-treated (UHT), or fermented milk. The high conservation of milk miRs among various mammals underlines the importance of MEX-derived miRs in the epigenetic regulation for postnatal mammalian growth [153,165]. Notably, among all mammals, only humans experience life-long exposure to cow milk signaling overactivating mTORC1 (Figure 3).

Milk consumption during pregnancy already promotes fetal overgrowth via abundant supply of essential amino acids and placental transfer of bovine MEX and their miRs [209,239-243]. Milk accelerates BMI [258], early onset of menarche [251], skeletal growth and height $[42,256,257]$, sebaceous gland hyperplasia, and sebaceous lipogenesis promoting mTORC1-driven acne vulgaris [274,277,278]. Milk consumption during adult life is associated with higher risks of common mTORC1-driven cancers, including PCa [307-316], BC [345-349], HCC [410,411,417], DLBCL [424], and promotes the neurodegenerative diseases PD [440-445] and AD [480-482], which are all related to overstimulated mTORC1 signaling (Figure 3). Thus, milk's physiological function to maintain high mTORC1 signaling at the beginning of mammalian life turns into adverse health effects 
when this postnatal endocrine and epigenetic system is not discontinued as designated by the physiological processing of the lactation genome. A deeper understanding of milk's interaction with the central hub of metabolic regulation, mTORC1, will open new avenues for prevention of common diseases of civilization.

Funding: This research received no external funding.

Institutional Review Board Statement: Not applicable.

Informed Consent Statement: Not applicable.

Data Availability Statement: All-data are derived from reviewed publishes references listed in the PubMed data base.

Acknowledgments: The author thanks Claus Leitzmann, University of Giessen, Germany, for providing data of amino acid composition of selected dietary sources and discussion of the research matter. The author thanks Gerd Schmitz, University of Regensburg, Germany, and Swen Malte John, University of Osnabrück, Germany, for their continuous support and valuable discussions on milk's molecular biology and pathology in health and disease.

Conflicts of Interest: The author declares no conflict of interest.

$\begin{array}{ll}\text { Abbreviations } \\ \text { A } 3 & \text { B-amyloid } \\ \text { AD } & \text { Alzheimer's disease } \\ \text { AMD1 } & \text { S-adenosylmethionine decarboxylase 1 } \\ \text { AMPK } & \text { adenosine monophosphate-activated protein kinase } \\ \text { APP } & \text { amyloid precursor protein } \\ \text { AR } & \text { androgen receptor } \\ \text { ARF1 } & \text { ADP-ribosylation factor 1 } \\ \text { ARIC } & \text { Atherosclerosis Risk in Communities } \\ \text { BAK1 } & \text { BCL2 antagonist killer 1 } \\ \text { BC } & \text { breast cancer } \\ \text { BCAA } & \text { branched-chain amino acid } \\ \text { BCKD } & \text { branched-chain alpha-ketoacid dehydrogenase } \\ \text { BMI } & \text { body mass index } \\ \text { BRCA1 } & \text { breast cancer 1 protein } \\ \text { BTB } & \text { broad complex, tramtrack, and bric-a-brac } \\ \text { CAND1 } & \text { cullin-associated and neddylation-dissociated 1 } \\ \text { CASTOR1 } & \text { cellular arginine sensor for mTORC1 } \\ \text { CDKN1B } & \text { cyclin-dependent kinase inhibitor 1B } \\ \text { CMA } & \text { chaperone-mediated autophagy } \\ \text { CUL3 } & \text { cullin 3 } \\ \text { DBT } & \text { dihydrolipoamide branched-chain transacylase } \\ \text { DLBCL } & \text { diffuse large B-cell lymphoma } \\ \text { DMT2 } & \text { diabetes mellitus type 2 } \\ \text { DNMT } & \text { DNA methyltransferase } \\ \text { eIF4e } & \text { eukaryotic translation initiation factor 4E } \\ \text { GAP } & \text { GTPase-activating protein } \\ \text { E2F1 } & \text { E2F transcription factor 1 } \\ \text { EMT } & \text { epithelial-mesenchymal transition } \\ \text { EPIC } & \text { European Prospective Investigation into Cancer and Nutrition } \\ \text { ER } & \text { estrogen receptor } \\ \text { ERBB2 } & \text { ERB-B2 receptor tyrosine kinase 2 } \\ \text { ERR } \alpha & \text { estrogen-related receptor alpha } \\ \text { ER stress } & \text { endoplasmic reticulum stress } \\ \text { EV } & \text { extracellular vesicle } \\ \text { FBP } & \text { fructose-1,6-bisphosphate } \\ \text { FBXW7 } & \text { F-box and WD40 domain protein 7 } \\ \text { FOXO } & \text { forkhead box transcription factor } \\ & \end{array}$




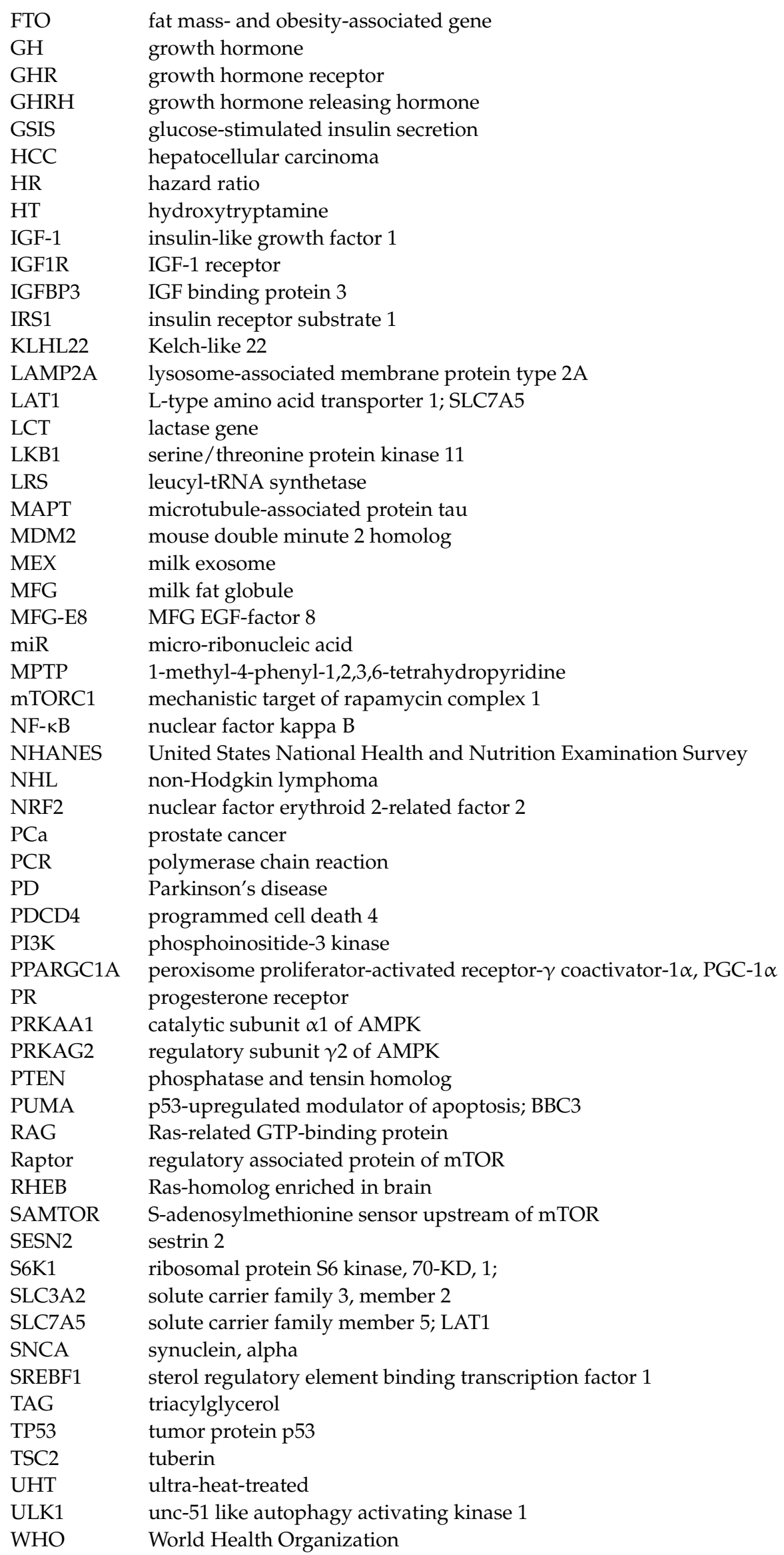




\section{References}

1. Willett, W.C.; Ludwig, D.S. Milk and health. N. Engl. J. Med. 2020, 382, 644-654. [CrossRef]

2. Zhang, X.; Chen, X.; Xu, Y.; Yang, J.; Du, L.; Li, K.; Zhou, Y. Milk consumption and multiple health outcomes: Umbrella review of systematic reviews and meta-analyses in humans. Nutr. Metab. 2021, 18, 7. [CrossRef]

3. Milchindustrie-Verband, E. V: Deutschland: Pro-Kopfverbrauch von Milchprodukten, Stand April 2020. Available online: https:/ / milchindustrie.de/wp-content/uploads/2020/04/ProkopfDeutschland_Mopro_2013-2019x_Homepage.pdf (accessed on 16 February 2021).

4. Ridder, M. Statista: Per capita consumption of milk in Sweden 2008-2018. Available online: https:/ /www.statista.com/statistics/ 557618/per-capita-consumption-of-milk-in-sweden/ (accessed on 16 February 2021).

5. Available online: https://www.statista.com/statistics/1098497/china-per-capita-milk-dairy-consumption/\#statisticContainer (accessed on 16 February 2021).

6. Melnik, B.C.; John, S.M.; Schmitz, G. Milk is not just food but most likely a genetic transfection system activating mTORC1 signaling for postnatal growth. Nutr. J. 2013, 12, 103. [CrossRef] [PubMed]

7. Melnik, B.C. Milk-A nutrient system of mammalian evolution promoting mTORC1-dependent translation. Int. J. Mol. Sci. 2015, 16, 17048-17087. [CrossRef]

8. Melick, C.H.; Jewell, J.L. Regulation of mTORC1 by upstream stimuli. Genes 2020, 11, 989. [CrossRef]

9. Melnik, B.C.; Schmitz, G. Pasteurized non-fermented cow's milk but not fermented milk is a promoter of mTORC1-driven aging and increased mortality. Ageing Res. Rev. 2021, 67, 101270. [CrossRef] [PubMed]

10. WHO. Available online: https://www.who.int/news/item/15-01-2011-exclusive-breastfeeding-for-six-months-best-for-babieseverywhere (accessed on 16 February 2021).

11. Haschke, F.; Grathwohl, D.; Haiden, N. Metabolic programming: Effects of early nutrition on growth, metabolism and body composition. Nestle Nutr. Inst. Workshop Ser. 2016, 86, 87-95. [PubMed]

12. Haschke, F.; Binder, C.; Huber-Dangl, M.; Haiden, N. Early-life nutrition, growth trajectories, and long-term outcome. Nestle Nutr. Inst. Workshop Ser. 2019, 90, 107-120. [PubMed]

13. Eriksen, K.G.; Christensen, S.H.; Lind, M.V.; Michaelsen, K.F. Human milk composition and infant growth. Curr. Opin. Clin. Nutr. Metab. Care 2018, 21, 200-206. [CrossRef] [PubMed]

14. Howell, J.J.; Ricoult, S.J.; Ben-Sahra, I.; Manning, B.D. A growing role for mTOR in promoting anabolic metabolism. Biochem. Soc. Trans. 2013, 41, 906-912. [CrossRef] [PubMed]

15. Ben-Sahra, I.; Manning, B.D. mTORC1 signaling and the metabolic control of cell growth. Curr. Opin. Cell Biol. $2017,45,72-82$. [CrossRef] [PubMed]

16. Rabanal-Ruiz, Y.; Korolchuk, V.I. mTORC1 and nutrient homeostasis: The central role of the lysosome. Int. J. Mol. Sci. 2018, 19, 818. [CrossRef]

17. Tee, A.R. The target of rapamycin and mechanisms of cell growth. Int. J. Mol. Sci. 2018, 19, 880. [CrossRef] [PubMed]

18. Condon, K.J.; Sabatini, D.M. Nutrient regulation of mTORC1 at a glance. J. Cell Sci. 2019, 132, jcs222570. [CrossRef]

19. Zhu, M.; Wang, X.Q. Regulation of mTORC1 by small GTPases in response to nutrients. J. Nutr. 2020, 150, 1004-1011. [CrossRef] [PubMed]

20. Rich-Edwards, J.W.; Ganmaa, D.; Pollak, M.N.; Nakamoto, E.K.; Kleinman, K.; Tserendolgor, U.; Willett, W.C.; Frazier, A.L. Milk consumption and the prepubertal somatotropic axis. Nutr. J. 2007, 6, 28. [CrossRef]

21. Barrea, L.; Di Somma, C.; Macchia, P.E.; Falco, A.; Savanelli, M.C.; Orio, F.; Colao, A.; Savastano, S. Influence of nutrition on somatotropic axis: Milk consumption in adult individuals with moderate-severe obesity. Clin Nutr. 2017, 36, 293-301. [CrossRef] [PubMed]

22. Rogers, I.; Emmett, P.; Gunnell, D.; Dunger, D.; Holly, J.; ALSPAC Study Team. Milk as a food for growth? The insulin-like growth factors link. Public Health Nutr. 2006, 9, 359-368. [CrossRef] [PubMed]

23. Norat, T.; Dossus, L.; Rinaldi, S.; Overvad, K.; Grønbaek, H.; Tjønneland, A.; Olsen, A.; Clavel-Chapelon, F.; Boutron-Ruault, M.C.; Boeing, H.; et al. Diet, serum insulin-like growth factor-I and IGF-binding protein-3 in European women. Eur. J. Clin. Nutr. 2007, 61, 91-98. [CrossRef]

24. Crowe, F.L.; Key, T.J.; Allen, N.E.; Appleby, P.N.; Roddam, A.; Overvad, K.; Grønbaek, H.; Tjønneland, A.; Halkjaer, J.; Dossus, L.; et al. The association between diet and serum concentrations of IGF-I, IGFBP-1, IGFBP-2, and IGFBP-3 in the European Prospective Investigation into Cancer and Nutrition. Cancer Epidemiol. Biomarkers Prev. 2009, 18, 1333-1340. [CrossRef]

25. Qin, L.Q.; He, K.; Xu, J.Y. Milk consumption and circulating insulin-like growth factor-I level: A systematic literature review. Int. J. Food Sci. Nutr. 2009, 60 (Suppl. 7), 330-340. [CrossRef]

26. Romo Ventura, E.; Konigorski, S.; Rohrmann, S.; Schneider, H.; Stalla, G.K.; Pischon, T.; Linseisen, J.; Nimptsch, K. Association of dietary intake of milk and dairy products with blood concentrations of insulin-like growth factor 1 (IGF-1) in Bavarian adults. Eur. J. Nutr. 2020, 59, 1413-1420. [CrossRef]

27. Blum, J.W.; Baumrucker, C.R. Insulin-like growth factors (IGFs), IGF binding proteins, and other endocrine factors in milk: Role in the newborn. Adv. Exp. Med. Biol. 2008, 606, 397-422.

28. Meyer, Z.; Höflich, C.; Wirthgen, E.; Olm, S.; Hammon, H.M.; Hoeflich, A. Analysis of the IGF-system in milk from farm animals-Occurrence, regulation, and biomarker potential. Growth Horm. IGF Res. 2017, 35, 1-7. [CrossRef] 
29. Hoeflich, A.; Meyer, Z. Functional analysis of the IGF-system in milk. Best Pract. Res. Clin. Endocrinol. Metab. 2017, 31, 409-418. [CrossRef]

30. Francis, G.L.; Upton, F.M.; Ballard, F.J.; McNeil, K.A.; Wallace, J.C. Insulin-like growth factors 1 and 2 in bovine colostrum. Sequences and biological activities compared with those of a potent truncated form. Biochem. J. 1988, 251, 95-103. [CrossRef]

31. Mauras, N.; Rogol, A.D.; Haymond, M.W.; Veldhuis, J.D. Sex steroids, growth hormone, insulin-like growth factor-1: Neuroendocrine and metabolic regulation in puberty. Horm. Res. 1996, 45, 74-80. [CrossRef]

32. Benyi, E.; Sävendahl, L. The physiology of childhood growth: Hormonal regulation. Horm. Res. Paediatr. 2017, 88, 6-14. [CrossRef]

33. Mullen, M.P.; Lynch, C.O.; Waters, S.M.; Howard, D.J.; O’Boyle, P.; Kenny, D.A.; Buckley, F.; Horan, B.; Diskin, M.G. Single nucleotide polymorphisms in the growth hormone and insulin-like growth factor-1 genes are associated with milk production, body condition score and fertility traits in dairy cows. Genet. Mol. Res. 2011, 10, 1819-1830. [CrossRef]

34. Daxenberger, A.; Breier, B.H.; Sauerwein, H. Increased milk levels of insulin-like growth factor 1 (IGF-1) for the identification of bovine somatotropin (bST) treated cows. Analyst 1998, 123, 2429-2435. [CrossRef]

35. Harp, J.B.; Goldstein, S.; Phillips, L.S. Nutrition and somatomedin. XXIII. Molecular regulation of IGF-I by amino acid availability in cultured hepatocytes. Diabetes 1991, 40, 95-101. [CrossRef] [PubMed]

36. Wheelhouse, N.M.; Stubbs, A.K.; Lomax, M.A.; MacRae, J.C.; Hazlerigg, D.G. Growth hormone and amino acid supply interact synergistically to control insulin-like growth factor-I production and gene expression in cultured ovine hepatocytes. J. Endocrinol. 1999, 163, 353-361. [CrossRef]

37. Miller, R.A.; Buehner, G.; Chang, Y.; Harper, J.M.; Sigler, R.; Smith-Wheelock, M. Methionine-deficient diet extends mouse lifespan, slows immune and lens aging, alters glucose, T4, IGF-I and insulin levels, and increases hepatocyte MIF levels and stress resistance. Aging Cell 2005, 4, 119-125. [CrossRef]

38. Dukes, A.; Davis, C.; El Refaey, M.; Upadhyay, S.; Mork, S.; Arounleut, P.; Johnson, M.H.; Hill, W.D.; Isales, C.M.; Hamrick, M.W. The aromatic amino acid tryptophan stimulates skeletal muscle IGF1/p70s6k/mTor signaling in vivo and the expression of myogenic genes in vitro. Nutrition 2015, 31, 1018-1024. [CrossRef] [PubMed]

39. Fleddermann, M.; Demmelmair, H.; Grote, V.; Bidlingmaier, M.; Grimminger, P.; Bielohuby, M.; Koletzko, B. Role of selected amino acids on plasma IGF-I concentration in infants. Eur. J. Nutr. 2017, 56, 613-620. [CrossRef] [PubMed]

40. Oh, H.S.; Oh, S.K.; Lee, J.S.; Wu, C.; Lee, S.J. Effects of l-arginine on growth hormone and insulin-like growth factor 1. Food Sci. Biotechnol. 2017, 26, 1749-1754. [CrossRef] [PubMed]

41. Tsugawa, Y.; Handa, H.; Imai, T. Arginine induces IGF-1 secretion from the endoplasmic reticulum. Biochem. Biophys. Res. Commun. 2019, 514, 1128-1132. [CrossRef]

42. Hoppe, C.; Mølgaard, C.; Michaelsen, K.F. Cow's milk and linear growth in industrialized and developing countries. Annu. Rev. Nutr. 2006, 26, 131-173. [CrossRef]

43. Wiley, A.S. Cow milk consumption, insulin-like growth factor-I, and human biology: A life history approach. Am. J. Hum. Biol. 2012, 24, 130-138. [CrossRef]

44. Martin, R.M.; Holly, J.M.; Gunnell, D. Milk and linear growth: Programming of the igf-I axis and implication for health in adulthood. Nestle Nutr. Workshop Ser. Pediatr. Program. 2011, 67, 79-97.

45. Bromek, E.; Rysz, M.; Haduch, A.; Daniel, W.A. Serotonin receptors of 5-HT2 type in the hypothalamic arcuate nuclei positively regulate liver cytochrome P450 via stimulation of the growth hormone-releasing hormone/growth hormone hormonal pathway. Drug Metab. Dispos. 2019, 47, 80-85. [CrossRef] [PubMed]

46. Vottero, A.; Guzzetti, C.; Loche, S. New aspects of the physiology of the GH-IGF-1 axis. Endocr. Dev. 2013, $24,96-105$.

47. Takahashi, Y. The role of growth hormone and insulin-like growth factor-I in the liver. Int. J. Mol. Sci. 2017, 18, 1447. [CrossRef]

48. Huang, J.; Manning, B.D. The TSC1-TSC2 complex: A molecular switchboard controlling cell growth. Biochem J. 2008, 412, 179-190. [CrossRef]

49. Foster, K.G.; Fingar, D.C. Mammalian target of rapamycin (mTOR): Conducting the cellular signaling symphony. J. Biol. Chem. 2010, 285, 14071-14077. [CrossRef]

50. Menon, S.; Dibble, C.C.; Talbott, G.; Hoxhaj, G.; Valvezan, A.J.; Takahashi, H.; Cantley, L.C.; Manning, B.D. Spatial control of the TSC complex integrates insulin and nutrient regulation of mTORC1 at the lysosome. Cell 2014, 156, 771-785. [CrossRef] [PubMed]

51. Dibble, C.C.; Cantley, L.C. Regulation of mTORC1 by PI3K signaling. Trends Cell Biol. 2015, 25, 545-555. [CrossRef]

52. Johnson, S.C. Nutrient sensing, signaling and ageing: The role of IGF-1 and mTOR in ageing and age-related disease. Subcell. Biochem. 2018, 90, 49-97.

53. Ostman, E.M.; Liljeberg Elmståhl, H.G.; Björck, I.M. Inconsistency between glycemic and insulinemic responses to regular and fermented milk products. Am. J. Clin. Nutr. 2001, 74, 96-100. [CrossRef] [PubMed]

54. Hoyt, G.; Hickey, M.S.; Cordain, L. Dissociation of the glycaemic and insulinaemic responses to whole and skimmed milk. Br. J. Nutr. 2005, 93, 175-177. [CrossRef]

55. Power, O.; Hallihan, A.; Jakeman, P. Human insulinotropic response to oral ingestion of native and hydrolysed whey protein. Amino Acids 2009, 37, 333-339. [CrossRef] [PubMed]

56. Yang, J.; Chi, Y.; Burkhardt, B.R.; Guan, Y.; Wolf, B.A. Leucine metabolism in regulation of insulin secretion from pancreatic beta cells. Nutr. Rev. 2010, 68, 270-279. [CrossRef] [PubMed]

57. Boirie, Y.; Dangin, M.; Gachon, P.; Vasson, M.P.; Maubois, J.L.; Beaufrère, B. Slow and fast dietary proteins differently modulate postprandial protein accretion. Proc. Natl. Acad. Sci. USA 1997, 94, 14930-14935. [CrossRef] [PubMed] 
58. Moore, W.T.; Bowser, S.M.; Fausnacht, D.W.; Staley, L.L.; Suh, K.S.; Liu, D. Beta cell function and the nutritional state: Dietary factors that influence insulin secretion. Curr. Diab. Rep. 2015, 15, 76. [CrossRef]

59. Hoppe, C.; Mølgaard, C.; Dalum, C.; Vaag, A.; Michaelsen, K.F. Differential effects of casein versus whey on fasting plasma levels of insulin, IGF-1 and IGF-1/IGFBP-3: Results from a randomized 7-day supplementation study in prepubertal boys. Eur. J. Clin. Nutr. 2009, 63, 1076-1083. [CrossRef] [PubMed]

60. Straus, D.S. Growth-stimulatory actions of insulin in vitro and in vivo. Endocr. Rev. 1984, 5, 356-369. [CrossRef] [PubMed]

61. Sandow, J. Growth effects of insulin and insulin analogues. Arch. Physiol. Biochem. 2009, 115, 72-85. [CrossRef]

62. Zoncu, R.; Efeyan, A.; Sabatini, D.M. mTOR: From growth signal integration to cancer, diabetes and ageing. Nat. Rev. Mol. Cell Biol. 2011, 12, 21-35. [CrossRef] [PubMed]

63. Hyun, S. Body size regulation and insulin-like growth factor signaling. Cell Mol. Life Sci. 2013, 70, 2351-2365. [CrossRef]

64. Manning, B.D.; Toker, A. AKT/PKB signaling: Navigating the network. Cell 2017, 169, 381-405. [CrossRef]

65. Tokarz, V.L.; MacDonald, P.E.; Klip, A. The cell biology of systemic insulin function. J. Cell Biol. 2018, 217, 2273-2289. [CrossRef]

66. Souci, S.W.; Fachmann, W.; Kraut, H. (Eds.) Food Composition and Nutrition Tables, 8th revised and extended edition; MedPharm: Stuttgart, Germany, 2016; Volume XXXII, 1263p.

67. Millward, D.J.; Layman, D.K.; Tomé, D.; Schaafsma, G. Protein quality assessment: Impact of expanding understanding of protein and amino acid needs for optimal health. Am. J. Clin. Nutr. 2008, 87, 1576S-1581S. [CrossRef] [PubMed]

68. Lenders, C.M.; Liu, S.; Wilmore, D.W.; Sampson, L.; Dougherty, L.W.; Spiegelman, D.; Willett, W.C. Evaluation of a novel food composition database that includes glutamine and other amino acids derived from gene sequencing data. Eur. J. Clin. Nutr. 2009, 63, 1433-1439. [CrossRef]

69. Durán, R.V.; Oppliger, W.; Robitaille, A.M.; Heiserich, L.; Skendaj, R.; Gottlieb, E.; Hall, M.N. Glutaminolysis activates RagmTORC1 signaling. Mol Cell. 2012, 47, 349-358. [CrossRef]

70. Durán, R.V.; Hall, M.N. Glutaminolysis feeds mTORC1. Cell Cycle 2012, 11, 4107-4108. [CrossRef]

71. He, T.; Giuseppin, M.L. Slow and fast dietary proteins differentially modulate postprandial metabolism. Int. J. Food Sci. Nutr. 2014, 65, 386-390. [CrossRef]

72. Moro, T.; Brightwell, C.R.; Velarde, B.; Fry, C.S.; Nakayama, K.; Sanbongi, C.; Volpi, E.; Rasmussen, B.B. Whey protein hydrolysate increases amino acid uptake, mTORC1 signaling, and protein synthesis in skeletal muscle of healthy young men in a randomized crossover trial. J. Nutr. 2019, 149, 1149-1158. [CrossRef] [PubMed]

73. Avruch, J.; Long, X.; Ortiz-Vega, S.; Rapley, J.; Papageorgiou, A.; Dai, N. Amino acid regulation of TOR complex 1. Am. J. Physiol. Endocrinol. Metab. 2009, 296, E592-E602. [CrossRef]

74. Kim, S.G.; Buel, G.R.; Blenis, J. Nutrient regulation of the mTOR complex 1 signaling pathway. Mol. Cells 2013, 35, 463-473. [CrossRef]

75. Jewell, J.L.; Russell, R.C.; Guan, K.L. Amino acid signalling upstream of mTOR. Nat. Rev. Mol. Cell Biol. 2013, 14, 133-139. [CrossRef]

76. Bar-Peled, L.; Sabatini, D.M. Regulation of mTORC1 by amino acids. Trends Cell Biol. 2014, 24, 400-406. [CrossRef] [PubMed]

77. Zheng, X.; Liang, Y.; He, Q.; Yao, R.; Bao, W.; Bao, L.; Wang, Y.; Wang, Z. Current models of mammalian target of rapamycin complex 1 (mTORC1) activation by growth factors and amino acids. Int. J. Mol. Sci. 2014, 15, 20753-20769. [CrossRef]

78. Averous, J.; Lambert-Langlais, S.; Carraro, V.; Gourbeyre, O.; Parry, L.; B'Chir, W.; Muranishi, Y.; Jousse, C.; Bruhat, A.; Maurin, A.C.; et al. Requirement for lysosomal localization of mTOR for its activation differs between leucine and other amino acids. Cell Signal. 2014, 26, 1918-1927. [CrossRef]

79. Oshiro, N.; Rapley, J.; Avruch, J. Amino acids activate mammalian target of rapamycin (mTOR) complex 1 without changing Rag GTPase guanyl nucleotide charging. J. Biol. Chem. 2014, 289, 2658-2674. [CrossRef]

80. Jewell, J.L.; Kim, Y.C.; Russell, R.C.; Yu, F.X.; Park, H.W.; Plouffe, S.W.; Tagliabracci, V.S.; Guan, K.L. Metabolism. Differential regulation of mTORC1 by leucine and glutamine. Science 2015, 347, 194-198. [CrossRef]

81. Wang, S.; Tsun, Z.Y.; Wolfson, R.L.; Shen, K.; Wyant, G.A.; Plovanich, M.E.; Yuan, E.D.; Jones, T.D.; Chantranupong, L.; Comb, W.; et al. Metabolism. Lysosomal amino acid transporter SLC38A9 signals arginine sufficiency to mTORC1. Science 2015, 347, 188-194. [CrossRef]

82. Duan, Y.; Li, F.; Tan, K.; Liu, H.; Li, Y.; Liu, Y.; Kong, X.; Tang, Y.; Wu, G.; Yin, Y. Key mediators of intracellular amino acids signaling to mTORC1 activation. Amino Acids 2015, 47, 857-867. [CrossRef]

83. Kim, J.; Kim, E. Rag GTPase in amino acid signaling. Amino Acids 2016, 48, 915-928. [CrossRef]

84. Powis, K.; De Virgilio, C. Conserved regulators of Rag GTPases orchestrate amino acid-dependent TORC1 signaling. Cell Discov. 2016, 2, 15049. [CrossRef]

85. Nicastro, R.; Sardu, A.; Panchaud, N.; De Virgilio, C. The architecture of the Rag GTPase signaling network. Biomolecules 2017, 7, 48. [CrossRef]

86. Wolfson, R.L.; Sabatini, D.M. The dawn of the age of amino acid sensors for the mTORC1 pathway. Cell Metab. 2017, 26, 301-309. [CrossRef] [PubMed]

87. Ramlaul, K.; Aylett, C.H.S. Signal integration in the (m)TORC1 growth pathway. Front. Biol. 2018, 13, 237-262. [CrossRef] [PubMed]

88. Li, X.Z.; Yan, X.H. Sensors for the mTORC1 pathway regulated by amino acids. J Zhejiang Univ. Sci. B 2019, 20, 699-712. [CrossRef] 
89. Meng, D.; Yang, Q.; Wang, H.; Melick, C.H.; Navlani, R.; Frank, A.R.; Jewell, J.L. Glutamine and asparagine activate mTORC1 independently of Rag GTPases. J. Biol. Chem. 2020, 295, 2890-2899. [CrossRef]

90. Segev, N.; Hay, N. Hijacking leucyl-tRNA synthetase for amino acid-dependent regulation of TORC1. Mol. Cell 2012, 46, 4-6. [CrossRef] [PubMed]

91. Bonfils, G.; Jaquenoud, M.; Bontron, S.; Ostrowicz, C.; Ungermann, C.; De Virgilio, C. Leucyl-tRNA synthetase controls TORC1 via the EGO complex. Mol. Cell 2012, 46, 105-110. [CrossRef]

92. Han, J.M.; Jeong, S.J.; Park, M.C.; Kim, G.; Kwon, N.H.; Kim, H.K.; Ha, S.H.; Ryu, S.H.; Kim, S. Leucyl-tRNA synthetase is an intracellular leucine sensor for the mTORC1-signaling pathway. Cell 2012, 149, 410-424. [CrossRef]

93. Yoon, M.S.; Son, K.; Arauz, E.; Han, J.M.; Kim, S.; Chen, J. Leucyl-tRNA synthetase activates Vps34 in amino acid-sensing mTORC1 signaling. Cell Rep. 2016, 16, 1510-1517. [CrossRef]

94. Choi, H.; Son, J.B.; Kang, J.; Kwon, J.; Kim, J.H.; Jung, M.; Kim, S.K.; Kim, S.; Mun, J.Y. Leucine-induced localization of Leucyl-tRNA synthetase in lysosome membrane. Biochem. Biophys. Res. Commun. 2017, 493, 1129-1135. [CrossRef]

95. Yoon, I.; Nam, M.; Kim, H.K.; Moon, H.S.; Kim, S.; Jang, J.; Song, J.A.; Jeong, S.J.; Kim, S.B.; Cho, S.; et al. Glucose-dependent control of leucine metabolism by leucyl-tRNA synthetase 1. Science 2020, 367, 205-210. [CrossRef]

96. Carroll, B.; Maetzel, D.; Maddocks, O.D.; Otten, G.; Ratcliff, M.; Smith, G.R.; Dunlop, E.A.; Passos, J.F.; Davies, O.R.; Jaenisch, R.; et al. Control of TSC2-Rheb signaling axis by arginine regulates mTORC1 activity. Elife 2016, 5, e11058. [CrossRef]

97. Groenewoud, M.J.; Zwartkruis, F.J. Rheb and Rags come together at the lysosome to activate mTORC1. Biochem. Soc. Trans. 2013, 41, 951-955. [CrossRef]

98. Jensen, R.G.; Ferris, A.M.; Lammi-Keefe, C.J.; Henderson, R.A. Lipids of bovine and human milks: A comparison. J. Dairy Sci. 1990, 73, 223-240. [CrossRef]

99. Saphier, O.; Blumenfeld, J.; Silberstein, T.; Tzor, T.; Burg, A. Fatty acid composition of breastmilk of Israeli mothers. Indian Pediatr. 2013, 50, 1044-1046. [CrossRef]

100. Qian, L.; Zhao, A.; Zhang, Y.; Chen, T.; Zeisel, S.H.; Jia, W.; Cai, W. Metabolomic approaches to explore chemical diversity of human breast-milk, formula milk and bovine milk. Int. J. Mol. Sci. 2016, 17, 2128. [CrossRef] [PubMed]

101. Bourlieu, C.; Michalski, M.C. Structure-function relationship of the milk fat globule. Curr. Opin. Clin. Nutr. Metab. Care 2015, 18, 118-127. [CrossRef] [PubMed]

102. Bassingthwaighte, J.B.; Noodleman, L.; van der Vusse, G.; Glatz, J.F. Modeling of palmitate transport in the heart. Mol. Cell Biochem. 1989, 88, 51-58. [CrossRef] [PubMed]

103. Suiter, C.; Singha, S.K.; Khalili, R.; Shariat-Madar, Z. Free fatty acids: Circulating contributors of metabolic syndrome. Cardiovasc. Hematol. Agents Med. Chem. 2018, 16, 20-34. [CrossRef]

104. Shaw, R.J. LKB1 and AMP-activated protein kinase control of mTOR signalling and growth. Acta Physiol. 2009, 196, 65-80. [CrossRef]

105. Carroll, B.; Dunlop, E.A. The lysosome: A crucial hub for AMPK and mTORC1 signalling. Biochem J. 2017, 474, 1453-1466. [CrossRef] [PubMed]

106. Hardie, D.G.; Lin, S.C. AMP-activated protein kinase-Not just an energy sensor. F1000Res. 2017, 6, 1724. [CrossRef]

107. Kwon, B.; Querfurth, H.W. Palmitate activates mTOR/p70S6K through AMPK inhibition and hypophosphorylation of raptor in skeletal muscle cells: Reversal by oleate is similar to metformin. Biochimie 2015, 118, 141-150. [CrossRef]

108. Yasuda, M.; Tanaka, Y.; Kume, S.; Morita, Y.; Chin-Kanasaki, M.; Araki, H.; Isshiki, K.; Araki, S.; Koya, D.; Haneda, M.; et al. Fatty acids are novel nutrient factors to regulate mTORC1 lysosomal localization and apoptosis in podocytes. Biochim. Biophys. Acta 2014, 1842, 1097-1108. [CrossRef]

109. Kumar, S.; Tikoo, K. Independent role of PP2A and mTORc1 in palmitate induced podocyte death. Biochimie 2015, 112, 73-84. [CrossRef]

110. Chen, Y.; Griffiths, A.; Wang, J.; Zhang, T.; Song, Q.; Song, Z. Inositol-requiring enzyme $1 \alpha$ links palmitate-induced mTOR activation and lipotoxicity in hepatocytes. Am. J. Physiol. Cell Physiol. 2020, 319, C1130-C1140. [CrossRef] [PubMed]

111. Li, H.; Xu, W.; Ma, Y.; Zhou, S.; Xiao, R. Milk fat globule membrane protein promotes C2C12 cell proliferation through the PI3K/Akt signaling pathway. Int. J. Biol. Macromol. 2018, 114, 1305-1314. [CrossRef] [PubMed]

112. Li, H.; Guan, K.; Li, X.; Ma, Y.; Zhou, S. MFG-E8 induced differences in proteomic profiles in mouse C2C12 cells and its effect on PI3K/Akt and ERK signal pathways. Int. J. Biol. Macromol. 2019, 124, 681-688. [CrossRef] [PubMed]

113. Ségurel, L.; Bon, C. On the evolution of lactase persistence in humans. Annu. Rev. Genomics Hum. Genet. 2017, 18, 297-319. [CrossRef]

114. Hardie, D.G. New roles for the LKB1->AMPK pathway. Curr. Opin. Cell Biol. 2005, 17, 167-173. [CrossRef]

115. Inoki, K.; Ouyang, H.; Zhu, T.; Lindvall, C.; Wang, Y.; Zhang, X.; Yang, Q.; Bennett, C.; Harada, Y.; Stankunas, K.; et al. TSC2 integrates Wnt and energy signals via a coordinated phosphorylation by AMPK and GSK3 to regulate cell growth. Cell 2006, 126, 955-968. [CrossRef] [PubMed]

116. Gwinn, D.M.; Shackelford, D.B.; Egan, D.F.; Mihaylova, M.M.; Mery, A.; Vasquez, D.S.; Turk, B.E.; Shaw, R.J. AMPK phosphorylation of raptor mediates a metabolic checkpoint. Mol. Cell 2008, 30, 214-226. [CrossRef]

117. Hardie, D.G. AMPK and Raptor: Matching cell growth to energy supply. Mol. Cell 2008, 30, 263-265. [CrossRef]

118. Herzig, S.; Shaw, R.J. AMPK: Guardian of metabolism and mitochondrial homeostasis. Nat. Rev. Mol. Cell Biol. 2018, 19, 121-135. [CrossRef] [PubMed] 
119. Zhang, C.S.; Hawley, S.A.; Zong, Y.; Li, M.; Wang, Z.; Gray, A.; Ma, T.; Cui, J.; Feng, J.W.; Zhu, M.; et al. Fructose-1,6-bisphosphate and aldolase mediate glucose sensing by AMPK. Nature 2017, 548, 112-116. [CrossRef] [PubMed]

120. Lin, S.C.; Hardie, D.G. AMPK: Sensing glucose as well as cellular energy status. Cell Metab. 2018, 27, 299-313. [CrossRef] [PubMed]

121. Umbayev, B.; Askarova, S.; Almabayeva, A.; Saliev, T.; Masoud, A.R.; Bulanin, D. Galactose-induced skin aging: The role of oxidative stress. Oxid. Med. Cell Longev. 2020, 2020, 7145656. [CrossRef]

122. Zhang, D.; Yan, B.; Yu, S.; Zhang, C.; Wang, B.; Wang, Y.; Wang, J.; Yuan, Z.; Zhang, L.; Pan, J. Coenzyme Q10 inhibits the aging of mesenchymal stem cells induced by D-galactose through Akt/mTOR signaling. Oxid. Med. Cell Longev. 2015, $2015,867293$. [CrossRef]

123. Zhang, D.; Chen, Y.; Xu, X.; Xiang, H.; Shi, Y.; Gao, Y.; Wang, X.; Jiang, X.; Li, N.; Pan, J. Autophagy inhibits the mesenchymal stem cell aging induced by D-galactose through ROS/JNK/p38 signalling. Clin. Exp. Pharmacol. Physiol. 2020, 47, 466-477. [CrossRef]

124. Chen, L.; Yao, H.; Chen, X.; Wang, Z.; Xiang, Y.; Xia, J.; Liu, Y.; Wang, Y. Ginsenoside Rg1 decreases oxidative stress and down-regulates Akt/mTOR signalling to attenuate cognitive impairment in mice and senescence of neural stem cells induced by D-galactose. Neurochem. Res. 2018, 43, 430-440. [CrossRef]

125. Liu, H.; Huang, B.; Xue, S.; Kin, P.U.; Tsang, L.L.; Zhang, X.; Li, G.; Jiang, X. Functional crosstalk between mTORC1/p70S6K pathway and heterochromatin organization in stress-induced senescence of MSCs. Stem Cell Res. Ther. 2020, 11, 279. [CrossRef]

126. Senger, D.R.; Li, D.; Jaminet, S.C.; Cao, S. Activation of the Nrf2 cell defense pathway by ancient foods: Disease prevention by important molecules and microbes lost from the modern Western diet. PLoS ONE 2016, 11, e0148042.

127. Rhee, S.G.; Bae, S.H. The antioxidant function of sestrins is mediated by promotion of autophagic degradation of Keap1 and Nrf2 activation and by inhibition of mTORC1. Free Radic. Biol. Med. 2015, 88 Pt B, 205-211. [CrossRef] [PubMed]

128. Capuco, A.V.; Akers, R.M. The origin and evolution of lactation. J. Biol. 2009, 8, 37. [CrossRef] [PubMed]

129. Lemay, D.G.; Lynn, D.J.; Martin, W.F.; Neville, M.C.; Casey, T.M.; Rincon, G.; Kriventseva, E.V.; Barris, W.C.; Hinrichs, A.S.; Molenaar, A.J.; et al. The bovine lactation genome: Insights into the evolution of mammalian milk. Genome Biol. 2009, 10, R43. [CrossRef] [PubMed]

130. Lefèvre, C.M.; Sharp, J.A.; Nicholas, K.R. Evolution of lactation: Ancient origin and extreme adaptations of the lactation system. Annu. Rev. Genomics Hum. Genet. 2010, 11, 219-238. [CrossRef]

131. Texada, M.J.; Koyama, T.; Rewitz, K. Regulation of body size and growth control. Genetics 2020, 216, 269-313. [CrossRef]

132. Golan-Gerstl, R.; Elbaum Shiff, Y.; Moshayoff, V.; Schecter, D.; Leshkowitz, D.; Reif, S. Characterization and biological function of milk-derived miRNAs. Mol. Nutr. Food Res. 2017, 61. [CrossRef]

133. Howard, K.M.; Kusuma, R.S.; Baier, S.R.; Friemel, T.; Markham, L.; Vanamala, J.; Zempleni, J. Loss of miRNAs during processing and storage of cow's (Bos taurus) milk. J. Agric. Food Chem. 2015, 63, 588-592. [CrossRef]

134. Manca, S.; Upadhyaya, B.; Mutai, E.; Desaulniers, A.T.; Cederberg, R.A.; White, B.R.; Zempleni, J. Milk exosomes are bioavailable and distinct microRNA cargos have unique tissue distribution patterns. Sci. Rep. 2018, 8, 11321. [CrossRef] [PubMed]

135. Kirchner, B.; Pfaffl, M.W.; Dumpler, J.; von Mutius, E.; Ege, M.J. microRNA in native and processed cow's milk and its implication for the farm milk effect on asthma. J. Allergy Clin. Immunol. 2016, 137, 1893-1895. [CrossRef] [PubMed]

136. Wang, L.; Sadri, M.; Giraud, D.; Zempleni, J. RNase H2-dependent polymerase chain reaction and elimination of confounders in sample collection, storage, and analysis strengthen evidence that microRNAs in bovine milk are bioavailable in humans. J. Nutr. 2018, 148, 153-159. [CrossRef] [PubMed]

137. Özdemir, S. Identification and comparison of exosomal microRNAs in the milk and colostrum of two different cow breeds. Gene 2020, 743, 144609. [CrossRef]

138. Izumi, H.; Kosaka, N.; Shimizu, T.; Sekine, K.; Ochiya, T.; Takase, M. Bovine milk contains microRNA and messenger RNA that are stable under degradative conditions. J. Dairy Sci. 2012, 95, 4831-4841. [CrossRef] [PubMed]

139. Benmoussa, A.; Lee, C.H.; Laffont, B.; Savard, P.; Laugier, J.; Boilard, E.; Gilbert, C.; Fliss, I.; Provost, P. Commercial dairy cow milk microRNAs resist digestion under simulated gastrointestinal tract conditions. J. Nutr. 2016, 146, 2206-2215. [CrossRef] [PubMed]

140. Kusuma, R.J.; Manca, S.; Friemel, T.; Sukreet, S.; Nguyen, C.; Zempleni, J. Human vascular endothelial cells transport foreign exosomes from cow's milk by endocytosis. Am. J. Physiol. Cell Physiol. 2016, 310, C800-C807. [CrossRef]

141. Melnik, B.C.; Kakulas, F.; Geddes, D.T.; Hartmann, P.E.; John, S.W.; Carrera-Bastos, P.C.; Cordain, L.; Schmitz, G. Milk miRNAs: Simple nutrients or systemic functional regulators? Nutr. Metab. 2016, 13, 42. [CrossRef]

142. Rani, P.; Vashisht, M.; Golla, N.; Shandilya, S.; Onteru, S.K.; Singh, D. Milk miRNAs encapsulated in exosomes are stable to human digestion and permeable to intestinal barrier in vitro. J. Funct. Foods 2017, 34, 431-439. [CrossRef]

143. Lönnerdal, B. Human milk microRNAs/exosomes: Composition and biological effects. Nestlé Nutr. Inst. Workshop Ser. 2019, 90, 83-92.

144. Lin, D.; Chen, T.; Xie, M.; Li, M.; Zeng, B.; Sun, R.; Zhu, Y.; Ye, D.; Wu, J.; Sun, J.; et al. Oral administration of bovine and porcine milk exosome alter miRNAs profiles in piglet serum. Sci. Rep. 2020, 10, 6983. [CrossRef]

145. Benmoussa, A.; Provost, P. Milk microRNAs in health and disease. Compr. Rev. Food Sci. Food Saf. 2019, 18, 703-722. [CrossRef]

146. Carrillo-Lozano, E.; Sebastián-Valles, F.; Knott-Torcal, C. Circulating microRNAs in breast milk and their potential impact on the infant. Nutrients 2020, 12, 3066. [CrossRef] 
147. Chen, Z.; Xie, Y.; Luo, J.; Chen, T.; Xi, Q.; Zhang, Y.; Sun, J. Milk exosome-derived miRNAs from water buffalo are implicated in immune response and metabolism process. BMC Vet. Res. 2020, 16, 123. [CrossRef] [PubMed]

148. Baier, S.R.; Nguyen, C.; Xie, F.; Wood, J.R.; Zempleni, J. MicroRNAs are absorbed in biologically meaningful amounts from nutritionally relevant doses of cow milk and affect gene expression in peripheral blood mononuclear cells, HEK-293 kidney cell cultures, and mouse livers. J. Nutr. 2014, 144, 1495-1500. [CrossRef]

149. Reif, S.; Elbaum Shiff, Y.; Golan-Gerstl, R. Milk-derived exosomes (MDEs) have a different biological effect on normal fetal colon epithelial cells compared to colon tumor cells in a miRNA-dependent manner. J. Transl. Med. 2019, 17, 325. [CrossRef] [PubMed]

150. Ozkan, H.; Tuzun, F.; Taheri, S.; Korhan, P.; Akokay, P.; Yılmaz, O.; Duman, N.; Özer, E.; Tufan, E.; Kumral, A.; et al. Epigenetic programming through breast milk and its impact on milk-siblings mating. Front. Genet. 2020, 11, 569232. [CrossRef]

151. Le Doare, K.; Holder, B.; Bassett, A.; Pannaraj, P.S. Mother's milk: A purposeful contribution to the development of the infant microbiota and immunity. Front. Immunol. 2018, 9, 361. [CrossRef]

152. Li, B.; Hock, A.; Wu, R.Y.; Minich, A.; Botts, S.R.; Lee, C.; Antounians, L.; Miyake, H.; Koike, Y.; Chen, Y.; et al. Bovine milk-derived exosomes enhance goblet cell activity and prevent the development of experimental necrotizing enterocolitis. PLOS ONE 2019, 14, e0211431. [CrossRef] [PubMed]

153. Melnik, B.C.; Schmitz, G. MicroRNAs: Milk's epigenetic regulators. Best Pract. Res. Clin. Endocrinol. Metab. 2017, 31, 427-442. [CrossRef] [PubMed]

154. Stremmel, W.; Weiskirchen, R.; Melnik, B.C. Milk exosomes prevent intestinal inflammation in a genetic mouse model of ulcerative colitis: A pilot experiment. Inflamm. Intest. Dis. 2020, 5, 117-123. [CrossRef] [PubMed]

155. Van Esch, B.C.A.M.; Porbahaie, M.; Abbring, S.; Garssen, J.; Potaczek, D.P.; Savelkoul, H.F.J.; van Neerven, R.J.J. The impact of milk and its components on epigenetic programming of immune function in early life and beyond: Implications for allergy and asthma. Front. Immunol. 2020, 11, 2141. [CrossRef]

156. Zempleni, J.; Aguilar-Lozano, A.; Sadri, M.; Sukreet, S.; Manca, S.; Wu, D.; Zhou, F.; Mutai, E. Biological activities of extracellular vesicles and their cargos from bovine and human milk in humans and implications for infants. J. Nutr. 2017, 147, 3-10. [CrossRef]

157. Zempleni, J.; Sukreet, S.; Zhou, F.; Wu, D.; Mutai, E. Milk-derived exosomes and metabolic regulation. Annu. Rev. Anim. Biosci. 2019, 7, 245-262. [CrossRef]

158. Xie, M.Y.; Hou, L.J.; Sun, J.J.; Zeng, B.; Xi, Q.Y.; Luo, J.Y.; Chen, T.; Zhang, Y.L. Porcine milk exosome miRNAs attenuate LPS-induced apoptosis through inhibiting TLR4/NF-kB and p53 pathways in intestinal epithelial cells. J. Agric. Food Chem. 2019, 67, 9477-9491. [CrossRef] [PubMed]

159. Melnik, B.C.; Schmitz, G. Exosomes of pasteurized milk: Potential pathogens of Western diseases. J. Transl. Med. 2019, 17, 3. [CrossRef] [PubMed]

160. Chen, X.; Gao, C.; Li, H.; Huang, L.; Sun, Q.; Dong, Y.; Tian, C.; Gao, S.; Dong, H.; Guan, D.; et al. Identification and characterization of microRNAs in raw milk during different periods of lactation, commercial fluid, and powdered milk products. Cell Res. 2010, 20, 1128-1137. [CrossRef] [PubMed]

161. Do, D.N.; Li, R.; Dudemaine, P.L.; Ibeagha-Awemu, E.M. MicroRNA roles in signalling during lactation: An insight from differential expression, time course and pathway analyses of deep sequence data. Sci. Rep. 2017, 7, 44605. [CrossRef] [PubMed]

162. Benmoussa, A.; Ly, S.; Shan, S.T.; Laugier, J.; Boilard, E.; Gilbert, C.; Provost, P. A subset of extracellular vesicles carries the bulk of microRNAs in commercial dairy cow's milk. J. Extracell. Vesicles 2017, 6, 1401897. [CrossRef] [PubMed]

163. Benmoussa, A.; Laugier, J.; Beauparlant, C.J.; Lambert, M.; Droit, A.; Provost, P. Complexity of the microRNA transcriptome of cow milk and milk-derived extracellular vesicles isolated via differential ultracentrifugation. J. Dairy Sci. 2020, 103, 16-29. [CrossRef] [PubMed]

164. Le Guillou, S.; Leduc, A.; Laubier, J.; Barbey, S.; Rossignol, M.N.; Lefebvre, R.; Marthey, S.; Laloë, D.; Le Provost, F. Characterization of Holstein and Normande whole milk miRNomes highlights breed specificities. Sci. Rep. 2019, 9, 20345. [CrossRef]

165. Van Herwijnen, M.J.C.; Driedonks, T.A.P.; Snoek, B.L.; Kroon, A.M.T.; Kleinjan, M.; Jorritsma, R.; Pieterse, C.M.J.; Hoen, E.N.M.N.; Wauben, M.H.M. Abundantly present miRNAs in milk-derived extracellular vesicles are conserved between mammals. Front. Nutr. 2018, 5, 81. [CrossRef] [PubMed]

166. Braud, M.; Magee, D.A.; Park, S.D.; Sonstegard, T.S.; Waters, S.M.; MacHugh, D.E.; Spillane, C. Genome-wide microRNA binding site variation between extinct wild aurochs and modern cattle identifies candidate microRNA-regulated domestication genes. Front. Genet. 2017, 8, 3. [CrossRef]

167. Do, D.N.; Dudemaine, P.L.; Li, R.; Ibeagha-Awemu, E.M. Co-expression network and pathway analyses reveal important modules of miRNAs regulating milk yield and component traits. Int. J. Mol. Sci. 2017, 18, 1560. [CrossRef]

168. Sanwlani, R.; Fonseka, P.; Chitti, S.V.; Mathivanan, S. Milk-derived extracellular vesicles in inter-organism, cross-species communication and drug delivery. Proteomes 2020, 8, 11. [CrossRef] [PubMed]

169. Pan, W.; Zhu, S.; Yuan, M.; Cui, H.; Wang, L.; Luo, X.; Li, J.; Zhou, H.; Tang, Y.; Shen, N. MicroRNA-21 and microRNA-148a contribute to DNA hypomethylation in lupus CD4+ T cells by directly and indirectly targeting DNA methyltransferase 1. J. Immunol. 2010, 184, 6773-6781. [CrossRef] [PubMed]

170. Melnik, B.C.; Kakulas, F. Milk exosomes and microRNAs: Potential epigenetic regulators. In Handbook of Nutrition, Diet, and Epigenetics; Patel, V., Preedy, V., Eds.; Springer: Cham, Switzerland, 2017; pp. 1-18.

171. Melnik, B.C.; Schmitz, G. Milk's role as an epigenetic regulator in health and disease. Diseases 2017, 5, 12. [CrossRef] [PubMed] 
172. Kuroda, A.; Rauch, T.A.; Todorov, I.; Ku, H.T.; Al-Abdullah, I.H.; Kandeel, F.; Mullen, Y.; Pfeifer, G.P.; Ferreri, K. Insulin gene expression is regulated by DNA methylation. PLoS ONE 2009, 4, e6953. [CrossRef]

173. Ouni, M.; Gunes, Y.; Belot, M.P.; Castell, A.L.; Fradin, D.; Bougnères, P. The IGF1 P2 promoter is an epigenetic QTL for circulating IGF1 and human growth. Clin. Epigenetics 2015, 7, 22. [CrossRef]

174. Liu, Z.W.; Zhang, J.T.; Cai, Q.Y.; Zhang, H.X.; Wang, Y.H.; Yan, H.T.; Wu, H.M.; Yang, X.J. Birth weight is associated with placental fat mass- and obesity-associated gene expression and promoter methylation in a Chinese population. J. Matern. Fetal Neonatal Med. 2016, 29, 106-111. [CrossRef] [PubMed]

175. Dayeh, T.; Volkov, P.; Salö, S.; Hall, E.; Nilsson, E.; Olsson, A.H.; Kirkpatrick, C.L.; Wollheim, C.B.; Eliasson, L.; Rönn, T.; et al. Genome-wide DNA methylation analysis of human pancreatic islets from type 2 diabetic and non-diabetic donors identifies candidate genes that influence insulin secretion. PLoS Genet. 2014, 10, e1004160. [CrossRef]

176. Toperoff, G.; Kark, J.D.; Aran, D.; Nassar, H.; Ahmad, W.A.; Sinnreich, R.; Azaiza, D.; Glaser, B.; Hellman, A. Premature aging of leukocyte DNA methylation is associated with type 2 diabetes prevalence. Clin. Epigenet. 2015, 7, 35. [CrossRef]

177. Rönn, T.; Ling, C. DNA methylation as a diagnostic and therapeutic target in the battle against type 2 diabetes. Epigenomics 2015, 7, 451-460. [CrossRef]

178. Gulati, P.; Cheung, M.K.; Antrobus, R.; Church, C.D.; Harding, H.P.; Tung, Y.C.; Rimmington, D.; Ma, M.; Ron, D.; Lehner, P.J.; et al. Role for the obesity-related FTO gene in the cellular sensing of amino acids. Proc. Natl. Acad. Sci. USA 2013, 110, $2557-2562$. [CrossRef]

179. Gulati, P.; Avezov, E.; Ma, M.; Antrobus, R.; Lehner, P.; O’Rahilly, S.; Yeo, G.S. Fat mass and obesity-related (FTO) shuttles between the nucleus and cytoplasm. Biosci Rep. 2014, 34, e00144. [CrossRef] [PubMed]

180. Chen, J.; Du, B. Novel positioning from obesity to cancer: FTO, an m6A RNA demethylase, regulates tumour progression. J. Cancer Res. Clin. Oncol. 2019, 145, 19-29. [CrossRef] [PubMed]

181. Lan, N.; Lu, Y.; Zhang, Y.; Pu, S.; Xi, H.; Nie, X.; Liu, J.; Yuan, W. FTO-A common genetic basis for obesity and cancer. Front. Genetics 2020, 11, 559138. [CrossRef] [PubMed]

182. Zhao, Q.; Zhao, Y.; Hu, W.; Zhang, Y.; Wu, X.; Lu, J.; Li, M.; Li, W.; Wu, W.; Wang, J.; et al. m6A RNA modification modulates $\mathrm{PI} 3 \mathrm{~K} / \mathrm{Akt} / \mathrm{mTOR}$ signal pathway in gastrointestinal cancer. Theranostics 2020, 10, 9528-9543. [CrossRef]

183. Wang, J.Y.; Chen, L.J.; Qiang, P. The potential role of N6-methyladenosine (m6A) demethylase fat mass and obesity-associated Gene (FTO) in human cancers. Onco Targets Ther. 2020, 13, 12845-12856. [CrossRef] [PubMed]

184. Melnik, B.C. Milk: An epigenetic amplifier of FTO-mediated transcription? Implications for Western diseases. J. Transl. Med. 2015, 13, 385. [CrossRef]

185. Cao, H.; Wang, L.; Chen, B.; Zheng, P.; He, Y.; Ding, Y.; Deng, Y.; Lu, X.; Guo, X.; Zhang, Y.; et al. DNA demethylation upregulated Nrf2 expression in Alzheimer's disease cellular model. Front. Aging Neurosci. 2016, 7, 244. [CrossRef]

186. Bendavit, G.; Aboulkassim, T.; Hilmi, K.; Shah, S.; Batist, G. Nrf2 transcription factor can directly regulate mTOR: Linking cytoprotective gene expression to a major metabolic regulator that generates redox activity. J. Biol. Chem. 2016, 291, 25476-25488 [CrossRef]

187. Gao, W.; Ge, S.; Sun, J. Ailanthone exerts anticancer effect by up-regulating miR-148a expression in MDA-MB-231 breast cancer cells and inhibiting proliferation, migration and invasion. Biomed. Pharmacother. 2019, 109, 1062-1069. [CrossRef] [PubMed]

188. Fromm, B.; Tosar, J.P.; Lu, Y.; Halushka, M.K.; Witwer, K.W. Human and cow have identical miR-21-5p and miR-30a-5p sequences, which are likely unsuited to study dietary uptake from cow milk. J. Nutr. 2018, 148, 1506-1507. [CrossRef] [PubMed]

189. Yang, Y.; Guo, J.X.; Shao, Z.Q. miR-21 targets and inhibits tumor suppressor gene PTEN to promote prostate cancer cell proliferation and invasion: An experimental study. Asian Pac. J. Trop. Med. 2017, 10, 87-91. [CrossRef] [PubMed]

190. Cao, L.Q.; Yang, X.W.; Chen, Y.B.; Zhang, D.W.; Jiang, X.F.; Xue, P. Exosomal miR-21 regulates the TETs/PTENp1/PTEN pathway to promote hepatocellular carcinoma growth [published correction appears in Mol. Cancer, 2020, 1, 59]. Mol. Cancer 2019, 18, 148. [CrossRef] [PubMed]

191. Liu, H.Y.; Zhang, Y.Y.; Zhu, B.L.; Feng, F.Z.; Yan, H.; Zhang, H.Y.; Zhou, B. miR-21regulates the proliferation and apoptosis of ovarian cancer cells through PTEN/PI3K/AKT. Eur. Rev. Med. Pharmacol. Sci. 2019, 23, 4149-4155.

192. Lu, Z.; Liu, M.; Stribinskis, V.; Klinge, C.M.; Ramos, K.S.; Colburn, N.H.; Li, Y. MicroRNA-21 promotes cell transformation by targeting the programmed cell death 4 gene. Oncogene 2008, 27, 4373-4379. [CrossRef]

193. Zhu, Q.; Wang, Z.; Hu, Y.; Li, J.; Li, X.; Zhou, L.; Huang, Y. miR-21 promotes migration and invasion by the miR-21-PDCD4-AP-1 feedback loop in human hepatocellular carcinoma. Oncol. Rep. 2012, 27, 1660-1668.

194. Yang, C.H.; Yue, J.; Pfeffer, S.R.; Fan, M.; Paulus, E.; Hosni-Ahmed, A.; Sims, M.; Qayyum, S.; Davidoff, A.M.; Handorf, C.R.; et al. MicroRNA-21 promotes glioblastoma tumorigenesis by down-regulating insulin-like growth factor-binding protein-3 (IGFBP3). J. Biol. Chem. 2014, 289, 25079-25087. [CrossRef]

195. Melnik, B.C. MiR-21: An environmental driver of malignant melanoma? J. Transl. Med. 2015, 13, 202. [CrossRef]

196. Pfeffer, S.R.; Yang, C.H.; Pfeffer, L.M. The role of miR-21 in cancer. Drug Dev. Res. 2015, 76, 270-277. [CrossRef]

197. Melnik, B.C.; John, S.M.; Carrera-Bastos, P.; Schmitz, G. MicroRNA-21-enriched exosomes as epigenetic regulators in melanomagenesis and melanoma progression: The impact of Western lifestyle factors. Cancers 2020, 12, 2111. [CrossRef]

198. Oh, S.; Park, M.R.; Son, S.J.; Kim, Y. Comparison of total RNA isolation methods for analysis of immune-related microRNAs in market milks. Korean J. Food Sci. Anim. Resour. 2015, 35, 459-465. [CrossRef] 
199. Baddela, V.S.; Nayan, V.; Rani, P.; Onteru, S.K.; Singh, D. Physicochemical biomolecular insights into Buffalo milk-derived nanovesicles. Appl. Biochem. Biotechnol. 2016, 178, 544-557. [CrossRef]

200. El Tayebi, H.M.; Waly, A.A.; Assal, R.A.; Hosny, K.A.; Esmat, G.; Abdelaziz, A.I. Transcriptional activation of the IGF-II/IGF-1R axis and inhibition of IGFBP-3 by miR-155 in hepatocellular carcinoma. Oncol. Lett. 2015, 10, 3206-3212. [CrossRef]

201. Sun, J.F.; Zhang, D.; Gao, C.J.; Zhang, Y.W.; Dai, Q.S. Exosome-mediated miR-155 transfer contributes to hepatocellular carcinoma cell proliferation by targeting PTEN. Med. Sci. Monit. Basic Res. 2019, 25, 218-228. [CrossRef]

202. Tang, B.; Lei, B.; Qi, G.; Liang, X.; Tang, F.; Yuan, S.; Wang, Z.; Yu, S.; He, S. MicroRNA-155-3p promotes hepatocellular carcinoma formation by suppressing FBXW7 expression. J. Exp. Clin. Cancer Res. 2016, 35, 93. [CrossRef] [PubMed]

203. Mao, J.H.; Kim, I.J.; Wu, D.; Climent, J.; Kang, H.C.; DelRosario, R.; Balmain, A. FBXW7 targets mTOR for degradation and cooperates with PTEN in tumor suppression. Science 2008, 321, 1499-1502. [CrossRef] [PubMed]

204. Li, R.; Dudemaine, P.L.; Zhao, X.; Lei, C.; Ibeagha-Awemu, E.M. Comparative analysis of the miRNome of bovine milk fat, whey and cells. PLoS ONE 2016, 11, e0154129. [CrossRef] [PubMed]

205. Ammah, A.A.; Do, D.N.; Bissonnette, N.; Gévry, N.; Ibeagha-Awemu, E.M. Co- expression network analysis identifies miRNAmRNA networks potentially regulating milk traits and blood metabolites. Int. J. Mol. Sci. 2018, 19, 2500. [CrossRef] [PubMed]

206. Le, M.T.; The, C.; Shyh-Chang, N.; Xie, H.; Zhou, B.; Korzh, V.; Lodish, H.F.; Lim, B. MicroRNA-125b is a novel negative regulator of p53. Genes. Dev. 2009, 23, 862-876. [CrossRef]

207. Kumar, M.; Lu, Z.; Takwi, A.A.; Chen, W.; Callander, N.S.; Ramos, K.S.; Young, K.H.; Li, Y. Negative regulation of the tumor suppressor p53 gene by microRNAs. Oncogene 2011, 30, 843-853. [CrossRef]

208. Melnik, B.C. Milk disrupts p53 and DNMT1, the guardians of the genome: Implications for acne vulgaris and prostate cancer. Nutr. Metab. 2017, 14, 55. [CrossRef]

209. Sadri, M.; Shu, J.; Kachman, S.D.; Cui, J.; Zempleni, J. Milk exosomes and miRNA cross the placenta and promote embryo survival in mice. Reproduction 2020, 160, 501-509. [CrossRef] [PubMed]

210. Vilella, F.; Moreno-Moya, J.M.; Balaguer, N.; Grasso, A.; Herrero, M.; Martínez, S.; Marcilla, A.; Simón, C. Hsa-miR-30d, secreted by the human endometrium, is taken up by the pre-implantation embryo and might modify its transcriptome. Development 2015, 142, 3210-3221. [CrossRef]

211. Feng, Z. p53 regulation of the IGF-1/AKT/mTOR pathways and the endosomal compartment. Cold Spring Harb. Perspect. Biol. 2010, 2, a001057. [CrossRef] [PubMed]

212. Buckbinder, L.; Talbott, R.; Velasco-Miguel, S.; Takenaka, I.; Faha, B.; Seizinger, B.R.; Kley, N. Induction of the growth inhibitor IGF-binding protein 3 by p53. Nature 1995, 377, 646-649. [CrossRef] [PubMed]

213. Feng, Z.; Hu, W.; de Stanchina, E.; Teresky, A.K.; Jin, S.; Lowe, S.; Levine, A.J. The regulation of AMPK beta1, TSC2, and PTEN expression by p53: Stress, cell and tissue specificity, and the role of these gene products in modulating the IGF-1-AKT-mTOR pathways. Cancer Res. 2007, 67, 3043-3053. [CrossRef]

214. Stambolic, V.M.; MacPherson, D.; Sas, D.; Lin, Y.; Snow, B.; Jang, Y.; Benchimol, S.; Mak, T.W. Regulation of PTEN transcription by p53. Mol. Cell 2001, 8, 317-325. [CrossRef]

215. Feng, Z.; Zhang, H.; Levine, A.J.; Jin, S. The coordinate regulation of the p53 and mTOR pathways in cells. Proc. Natl. Acad. Sci. USA 2005, 102, 8204-8209. [CrossRef]

216. Levine, A.J.; Feng, Z.; Mak, T.W.; You, H.; Jin, S. Coordination and communication between the p53 and IGF-1-AKT-TOR signal transduction pathways. Genes. Dev. 2006, 20, 267-275. [CrossRef]

217. Budanov, A.V.; Karin, M. p53 target genes sestrin1 and sestrin2 connect genotoxic stress and mTOR signaling. Cell 2008, 134, 451-460. [CrossRef]

218. Lee, J.H.; Cho, U.S.; Karin, M. Sestrin regulation of TORC1: Is Sestrin a leucine sensor? Sci. Signal. 2016, 9, re5. [CrossRef]

219. Wei, J.L.; Fang, M.; Fu, Z.X.; Zhang, S.R.; Guo, J.B.; Wang, R.; Lv, Z.B.; Xiong, Y.F. Sestrin 2 suppresses cells proliferation through AMPK/mTORC1 pathway activation in colorectal cancer. Oncotarget 2017, 8, 49318-49328. [CrossRef] [PubMed]

220. Wolf, T.; Baier, S.R.; Zempleni, J. The intestinal transport of bovine milk exosomes is mediated by endocytosis in human colon carcinoma Caco-2 cells and rat small intestinal IEC-6 cells. J. Nutr. 2015, 145, 2201-2216. [CrossRef] [PubMed]

221. Cicchini, C.; de Nonno, V.; Battistelli, C.; Cozzolino, A.M.; De Santis Puzzonia, M.; Ciafrè, S.A.; Brocker, C.; Gonzalez, F.J.; Amicone, L.; Tripodi, M. Epigenetic control of EMT/MET dynamics: HNF4 $\alpha$ impacts DNMT3s through miRs-29. Biochim. Biophys. Acta 2015, 1849, 919-929. [CrossRef]

222. Bian, Y.; Lei, Y.; Wang, C.; Wang, J.; Wang, L.; Liu, L.; Liu, L.; Gao, X.; Li, Q. Epigenetic regulation of miR-29s affects the lactation activity of dairy cow mammary epithelial cells. J. Cell Physiol. 2015, 230, 2152-2163. [CrossRef]

223. Zhang, J.; Wang, Y.; Liu, X.; Jiang, S.; Zhao, C.; Shen, R.; Guo, X.; Ling, X.; Liu, C. Expression and potential role of microRNA-29b in mouse early embryo development. Cell Physiol. Biochem. 2015, 35, 1178-1187. [CrossRef] [PubMed]

224. Zhang, Z.; Cao, Y.; Zhai, Y.; Ma, X.; An, X.; Zhang, S.; Li, Z. MicroRNA-29b regulates DNA methylation by targeting Dnmt3a/3b and Tet1/2/3 in porcine early embryo development. Dev. Growth Differ. 2018, 60, 197-204. [CrossRef]

225. Mersey, B.D.; Jin, P.; Danner, D.J. Human microRNA (miR29b) expression controls the amount of branched chain alpha-ketoacid dehydrogenase complex in a cell. Hum. Mol. Genet. 2005, 14, 3371-3377. [CrossRef]

226. Harris, R.A.; Popov, K.M.; Zhao, Y.; Shimomura, Y. Regulation of branched-chain amino acid catabolism. J. Nutr. 1994, 124 (Suppl. 8), 1499S-1502S. [CrossRef] 
227. Doering, C.B.; Williams, I.R.; Danner, D.J. Controlled overexpression of BCKD kinase expression: Metabolic engineering applied to BCAA metabolism in a mammalian system. Metab. Eng. 2000, 2, 349-356. [CrossRef] [PubMed]

228. Shimomura, Y.; Obayashi, M.; Murakami, T.; Harris, R.A. Regulation of branched-chain amino acid catabolism: Nutritional and hormonal regulation of activity and expression of the branched-chain alpha-keto acid dehydrogenase kinase. Curr. Opin. Clin. Nutr. Metab. Care 2001, 4, 419-423. [CrossRef]

229. Nellis, M.M.; Doering, C.B.; Kasinski, A.; Danner, D.J. Insulin increases branched-chain alpha-ketoacid dehydrogenase kinase expression in Clone 9 rat cells. Am. J. Physiol. Endocrinol. Metab. 2002, 283, E853-E860. [CrossRef] [PubMed]

230. Nie, C.; He, T.; Zhang, W.; Zhang, G.; Ma, X. Branched chain amino acids: Beyond nutrition metabolism. Int. J. Mol. Sci. 2018, 19, 954. [CrossRef] [PubMed]

231. Neinast, M.; Murashige, D.; Arany, Z. Branched chain amino acids. Annu. Rev. Physiol. 2019, 81, 139-164. [CrossRef]

232. Melnik, B.C. Milk-the promoter of chronic Western diseases. Med. Hypotheses 2009, 72, 631-639. [CrossRef]

233. Melnik, B.C.; John, S.M.; Schmitz, G. Over-stimulation of insulin/IGF-1 signaling by Western diet may promote diseases of civilization: Lessons learnt from Laron syndrome. Nutr. Metab. 2011, 8, 41. [CrossRef]

234. Olsen, S.F.; Halldorsson, T.I.; Willett, W.C.; Knudsen, V.K.; Gillman, M.W.; Mikkelsen, T.B.; Olsen, J.; NUTRIX Consortium. Milk consumption during pregnancy is associated with increased infant size at birth: Prospective cohort study. Am. J. Clin. Nutr. 2007, 86, 1104-1110. [CrossRef]

235. Heppe, D.H.; van Dam, R.M.; Willemsen, S.P.; den Breeijen, H.; Raat, H.; Hofman, A.; Steegers, E.A.; Jaddoe, V.W. Maternal milk consumption, fetal growth, and the risks of neonatal complications: The Generation R Study. Am. J. Clin. Nutr. 2011, 94, 501-509. [CrossRef]

236. Brantsæter, A.L.; Olafsdottir, A.S.; Forsum, E.; Olsen, S.F.; Thorsdottir, I. Does milk and dairy consumption during pregnancy influence fetal growth and infant birthweight? A systematic literature review. Food Nutr. Res. 2012, 56, 20050. [CrossRef]

237. Melnik, B.C.; John, S.M.; Schmitz, G. Milk consumption during pregnancy increases birth weight, a risk factor for the development of diseases of civilization. J. Transl. Med. 2015, 13, 13. [CrossRef] [PubMed]

238. Achón, M.; Úbeda, N.; García-González, Á.; Partearroyo, T.; Varela-Moreiras, G. Effects of milk and dairy product consumption on pregnancy and lactation outcomes: A systematic review. Adv. Nutr. 2019, 10 (Suppl. 2), S74-S87. [CrossRef] [PubMed]

239. Wen, H.Y.; Abbasi, S.; Kellems, R.E.; Xia, Y. mTOR: A placental growth signaling sensor. Placenta 2005, 26 (Suppl. A), S63-S69. [CrossRef] [PubMed]

240. Roos, S.; Lagerlöf, O.; Wennergren, M.; Powell, T.L.; Jansson, T. Regulation of amino acid transporters by glucose and growth factors in cultured primary human trophoblast cells is mediated by mTOR signaling. Am. J. Physiol. Cell Physiol. 2009, 297, C723-C731. [CrossRef]

241. Jansson, T.; Aye, I.L.; Goberdhan, D.C. The emerging role of mTORC1 signaling in placental nutrient-sensing. Placenta 2012, 33 (Suppl. 2), e23-e29. [CrossRef]

242. Gaccioli, F.; White, V.; Capobianco, E.; Powell, T.L.; Jawerbaum, A.; Jansson, T. Maternal overweight induced by a diet with high content of saturated fat activates placental mTOR and eIF2alpha signaling and increases fetal growth in rats. Biol. Reprod. 2013, 89, 96. [CrossRef]

243. Rosario, F.J.; Kanai, Y.; Powell, T.L.; Jansson, T. Mammalian target of rapamycin signalling modulates amino acid uptake by regulating transporter cell surface abundance in primary human trophoblast cells. J. Physiol. 2013, 591, 609-625. [CrossRef] [PubMed]

244. Xu, J.; Lu, C.; Wang, J.; Zhang, R.; Qian, X.; Zhu, H. Regulation of human trophoblast GLUT3 glucose transporter by mammalian target of rapamycin signaling. Int. J. Mol. Sci. 2015, 16, 13815-13828. [CrossRef] [PubMed]

245. Rosario, F.J.; Powell, T.L.; Gupta, M.B.; Cox, L.; Jansson, T. mTORC1 transcriptional regulation of ribosome subunits, protein synthesis, and molecular transport in primary human trophoblast cells. Front. Cell Dev. Biol. 2020, 8, 583801. [CrossRef]

246. Jiang, H.; Wu, W.; Zhang, M.; Li, J.; Peng, Y.; Miao, T.T.; Zhu, H.; Xu, G. Aberrant upregulation of miR-21 in placental tissues of macrosomia. J. Perinatol. 2014, 34, 658-663. [CrossRef]

247. Zhang, J.T.; Cai, Q.Y.; Ji, S.S.; Zhang, H.X.; Wang, Y.H.; Yan, H.T.; Yang, X.J. Decreased miR-143 and increased miR-21 placental expression levels are associated with macrosomia. Mol. Med. Rep. 2016, 13, 3273-3280. [CrossRef] [PubMed]

248. Melnik, B.C. The potential impact of maternal milk consumption during pregnancy on mTORC1-driven fetal growth. In Human Fetal Growth and Development; Bhattacharya, N., Stubblefield, P., Eds.; Springer: Cham, Switzerland, 2016; pp. $237-258$.

249. Pomar, C.A.; Castro, H.; Picó, C.; Serra, F.; Palou, A.; Sánchez, J. Cafeteria diet consumption during lactation in rats, rather than obesity per se, alters miR-222, miR-200a, and miR-26a levels in milk. Mol. Nutr. Food Res. 2019, 63, e1800928. [CrossRef] [PubMed]

250. Chen, Y.; Wang, J.; Yang, S.; Utturkar, S.; Crodian, J.; Cummings, S.; Thimmapuram, J.; San Miguel, P.; Kuang, S.; Gribskov, M.; et al. Effect of high-fat diet on secreted milk transcriptome in midlactation mice. Physiol. Genomics 2017, 49, 747-762. [CrossRef]

251. Wiley, A.S. Milk intake and total dairy consumption: Associations with early menarche in NHANES 1999-2004. PLoS ONE 2011, 6, e14685. [CrossRef] [PubMed]

252. Ramezani Tehrani, F.; Moslehi, N.; Asghari, G.; Gholami, R.; Mirmiran, P.; Azizi, F. Intake of dairy products, calcium, magnesium, and phosphorus in childhood and age at menarche in the Tehran Lipid and Glucose Study. PLoS ONE 2013, 8, e57696. [CrossRef]

253. Hosseini-Esfahani, F.; Hosseinpour-Niazi, S.; Asghari, G.; Bahadoran, Z.; Moslehi, N.; Golzarand, M.; Ejtahed, H.S.; Mirmiran, P.; Azizi, F. Nutrition and cardio-metabolic risk factors: Findings from 20 years of the Tehran Lipid and Glucose Study. Int. J. Endocrinol. Metab. 2018, 16 (Suppl. 4), e84772. [CrossRef] [PubMed] 
254. Hsieh, C.C.; Trichopoulos, D.; Katsouyanni, K.; Yuasa, S. Age at menarche, age at menopause, height and obesity as risk factors for breast cancer: Associations and interactions in an international case-control study. Int. J. Cancer 1990, 46, 796-800. [CrossRef]

255. Novotny, R.; Daida, Y.; Morimoto, Y.; Shepherd, J.; Maskarinec, G. Puberty, body fat, and breast density in girls of several ethnic groups. Am. J. Hum. Biol. 2011, 23, 359-365. [CrossRef]

256. Wiley, A.S. Consumption of milk, but not other dairy products, is associated with height among US preschool children in NHANES 1999-2002. Ann. Hum. Biol. 2009, 36, 125-138. [CrossRef]

257. Wiley, A.S. Does milk make children grow? Relationships between milk consumption and height in NHANES 1999-2002. Am. J. Hum. Biol. 2005, 17, 425-441. [CrossRef]

258. Wiley, A.S. Dairy and milk consumption and child growth: Is BMI involved? An analysis of NHANES 1999-2004. Am. J. Hum. Biol. 2010, 22, 517-525. [CrossRef]

259. Robeva, R.; Assyov, Y.; Tomova, A.; Kumanov, P. Acne vulgaris is associated with intensive pubertal development and altitude of residence-A cross-sectional population-based study on 6,200 boys. Eur. J. Pediatr. 2013, 172, 465-471. [CrossRef] [PubMed]

260. Di Landro, A.; Cazzaniga, S.; Parazzini, F.; Ingordo, V.; Cusano, F.; Atzori, L.; Cutrì, F.T.; Musumeci, M.L.; Zinetti, C.; Pezzarossa, E.; et al. Family history, body mass index, selected dietary factors, menstrual history, and risk of moderate to severe acne in adolescents and young adults. J. Am. Acad. Dermatol. 2012, 67, 1129-1135. [CrossRef]

261. Melnik, B.C.; John, S.M.; Plewig, G. Acne: Risk indicator for increased body mass index and insulin resistance. Acta Derm. Venereol. 2013, 93, 644-649. [CrossRef] [PubMed]

262. Grossi, E.; Cazzaniga, S.; Crotti, S.; Naldi, L.; Di Landro, A.; Ingordo, V.; Cusano, F.; Atzori, L.; Tripodi Cutrì, F.; Musumeci, M.L.; et al. The constellation of dietary factors in adolescent acne: A semantic connectivity map approach. J. Eur. Acad. Dermatol. Venereol. 2016, 30, 96-100. [CrossRef] [PubMed]

263. Juhl, C.R.; Bergholdt, H.K.M.; Miller, I.M.; Jemec, G.B.E.; Kanters, J.K.; Ellervik, C. Dairy intake and acne vulgaris: A systematic review and meta-analysis of 78,529 children, adolescents, and young adults. Nutrients 2018, 10, 1049. [CrossRef]

264. Dai, R.; Hua, W.; Chen, W.; Xiong, L.; Li, L. The effect of milk consumption on acne: A meta-analysis of observational studies. J. Eur. Acad. Dermatol. Venereol. 2018, 32, 2244-2253. [CrossRef]

265. Aghasi, M.; Golzarand, M.; Shab-Bidar, S.; Aminianfar, A.; Omidian, M.; Taheri, F. Dairy intake and acne development: A meta-analysis of observational studies. Clin. Nutr. 2019, 38, 1067-1075. [CrossRef] [PubMed]

266. Orrell, K.A.; Kelm, R.C.; Murphrey, M.; Nagiredla, S.; Wu, B.; Abu-Zayed, H.; Schlosser, B.J.; West, D.P.; Nardone, B. Frequency of acne in lactose-intolerant adults: A retrospective cross-sectional analysis within a large Midwestern US patient population. J. Eur. Acad. Dermatol. Venereol. 2019, 33, e190-e191. [CrossRef] [PubMed]

267. Sutcliffe, S.; Giovannucci, E.; Isaacs, W.B.; Willett, W.C.; Platz, E. A: Acne and risk of prostate cancer. Int. J. Cancer 2007, 121, 2688-2692. [CrossRef]

268. Ugge, H.; Udumyan, R.; Carlsson, J.; Andrén, O.; Montgomery, S.; Davidsson, S.; Fall, K. Acne in late adolescence and risk of prostate cancer. Int. J. Cancer 2018, 142, 1580-1585. [CrossRef]

269. Zhang, M.; Qureshi, A.A.; Fortner, R.T.; Hankinson, S.E.; Wei, Q.; Wang, L.E.; Eliassen, A.H.; Willett, W.C.; Hunter, D.J.; Han, J. Teenage acne and cancer risk in US women: A prospective cohort study. Cancer 2015, 121, 1681-1687. [CrossRef] [PubMed]

270. Murphy, J.D.; Sandler, D.; White, A.J.; O’Brien, K.M. Severe acne and risk of breast cancer. Breast Cancer Res. Treat. 2019, 177, 487-495. [CrossRef] [PubMed]

271. Moradi Tuchayi, S.; Makrantonaki, E.; Ganceviciene, R.; Dessinioti, C.; Feldman, S.R.; Zouboulis, C.C. Acne vulgaris. Nat. Rev. Dis. Primers 2015, 1, 15029. [CrossRef] [PubMed]

272. Plewig, G.; Melnik, B.; Chen, W.C. Acne pathogenesis. In Plewig and Kligman's Acne and Rosacea; Plewig, G., Melnik, B., Chen, W.C., Eds.; Springer: Berlin/Heidelberg, Germany, 2019; Chapter 3; pp. 45-61.

273. Melnik, B. Dietary intervention in acne: Attenuation of increased mTORC1 signaling promoted by Western diet. Dermatoendocrinology 2012, 4, 20-32. [CrossRef]

274. Melnik, B.C.; Zouboulis, C.C. Potential role of FoxO1 and mTORC1 in the pathogenesis of Western diet-induced acne. Exp. Dermatol. 2013, 22, 311-315. [CrossRef] [PubMed]

275. Danby, F.W. Turning acne on/off via mTORC1. Exp. Dermatol. 2013, 22, 505-506. [CrossRef]

276. Melnik, B.C. Acne vulgaris: An inflammasomopathy of the sebaceous follicle induced by deviated FoxO1/mTORC1 signalling. Br. J. Dermatol. 2016, 174, 1186-1188. [CrossRef] [PubMed]

277. Monfrecola, G.; Lembo, S.; Caiazzo, G.; De Vita, V.; Di Caprio, R.; Balato, A.; Fabbrocini, G. Mechanistic target of rapamycin (mTOR) expression is increased in acne patients' skin. Exp. Dermatol. 2016, 25, 153-155. [CrossRef]

278. Agamia, N.F.; Abdallah, D.M.; Sorour, O.; Mourad, B.; Younan, D.N. Skin expression of mammalian target of rapamycin and forkhead box transcription factor O1, and serum insulin-like growth factor-1 in patients with acne vulgaris and their relationship with diet. Br. J. Dermatol. 2016, 174, 1299-1307. [CrossRef]

279. Lembo, S.; Di Caprio, R.; Balato, A.; Caiazzo, G.; Fabbrocini, G.; Skroza, N.; Tolino, E.; Potenza, C. The increase of mTOR expression is consistent with FoxO1 decrease at gene level in acne but not in psoriasis. Arch. Dermatol. Res. 2020, 312, 77-80. [CrossRef]

280. Aktaş Karabay, E.; Saltık, Z.A.; Unay Demirel, Ö. Evaluation of serum FoxO1, mTORC1, IGF-1, IGFBP-3 levels, and metabolic syndrome components in patients with acne vulgaris: A prospective case-control study. Dermatol. Ther. 2020, 33 , e13887. [CrossRef] 
281. Melnik, B.C. Acne vulgaris: The metabolic syndrome of the pilosebaceous follicle. Clin. Dermatol. 2018, 36, 29-40. [CrossRef]

282. Del Prete, M.; Mauriello, M.C.; Faggiano, A.; Di Somma, C.; Monfrecola, G.; Fabbrocini, G.; Colao, A. Insulin resistance and acne: A new risk factor for men? Endocrine 2012, 42, 555-560. [CrossRef]

283. Kumari, R.; Thappa, D.M. Role of insulin resistance and diet in acne. Indian J. Dermatol. Venereol. Leprol. 2013, 79, 291-299. [CrossRef] [PubMed]

284. Nagpal, M.; De, D.; Handa, S.; Pal, A.; Sachdeva, N. Insulin resistance and metabolic syndrome in young men with acne. JAMA Dermatol. 2016, 152, 399-404. [CrossRef]

285. Melnik, B.C. Linking diet to acne metabolomics, inflammation, and comedogenesis: An update. Clin. Cosmet. Investig. Dermatol. 2015, 8, 371-388. [CrossRef] [PubMed]

286. Zick, Y. Ser/Thr phosphorylation of IRS proteins: A molecular basis for insulin resistance. Sci. STKE 2005, 2005, pe4. [CrossRef] [PubMed]

287. Um, S.H.; D'Alessio, D.; Thomas, G. Nutrient overload, insulin resistance, and ribosomal protein S6 kinase 1, S6K1. Cell Metab. 2006, 3, 393-402. [CrossRef]

288. Tremblay, F.; Brûlé, S.; Hee Um, S.; Li, Y.; Masuda, K.; Roden, M.; Sun, X.J.; Krebs, M.; Polakiewicz, R.D.; Thomas, G.; et al. Identification of IRS-1 Ser-1101 as a target of S6K1 in nutrient- and obesity-induced insulin resistance. Proc. Natl. Acad. Sci. USA 2007, 104, 14056-14061. [CrossRef]

289. Copps, K.D.; White, M.F. Regulation of insulin sensitivity by serine/threonine phosphorylation of insulin receptor substrate proteins IRS1 and IRS2. Diabetologia 2012, 55, 2565-2582. [CrossRef]

290. Hoppe, C.; Mølgaard, C.; Juul, A.; Michaelsen, K.F. High intakes of skimmed milk, but not meat, increase serum IGF-I and IGFBP-3 in eight-year-old boys. Eur. J. Clin. Nutr. 2004, 58, 1211-1216. [CrossRef] [PubMed]

291. Sluijs, I.; Forouhi, N.G.; Beulens, J.W.; van der Schouw, Y.T.; Agnoli, C.; Arriola, L.; Balkau, B.; Barricarte, A.; Boeing, H.; Bueno-de-Mesquita, H.B.; et al. Upstream signalling of mTORC1 and its hyperactivation in type 2 diabetes (T2D). BMB Rep. 2017, $50,601-609$.

292. Hruby, A.; Ma, J.; Rogers, G.; Meigs, J.B.; Jacques, P.F. Associations of dairy intake with incident prediabetes or diabetes in middle-aged adults vary by both dairy type and glycemic status. J. Nutr. 2017, 147, 1764-1775. [CrossRef] [PubMed]

293. Song, Y.; Chavarro, J.E.; Cao, Y.; Qiu, W.; Mucci, L.; Sesso, H.D.; Stampfer, M.J.; Giovannucci, E.; Pollak, M.; Liu, S.; et al. Whole milk intake is associated with prostate cancer-specific mortality among U.S. male physicians. J. Nutr. 2013, 143, 189-196. [CrossRef]

294. Brouwer-Brolsma, E.M.; Sluik, D.; Singh-Povel, C.M.; Feskens, E.J.M. Dairy product consumption is associated with pre-diabetes and newly diagnosed type 2 diabetes in the Lifelines Cohort Study. Br. J. Nutr. 2018, 119, 442-455. [CrossRef]

295. Melnik, B.C. Leucine signaling in the pathogenesis of type 2 diabetes and obesity. World J. Diabetes 2012, 3, 38-53. [CrossRef]

296. Melnik, B.C. The pathogenic role of persistent milk signaling in mTORC1- and milk-microRNA-driven type 2 diabetes mellitus. Curr. Diabetes Rev. 2015, 11, 46-62. [CrossRef]

297. Yuan, T.; Rafizadeh, S.; Gorrepati, K.D.; Lupse, B.; Oberholzer, J.; Maedler, K.; Ardestani, A. Reciprocal regulation of mTOR complexes in pancreatic islets from humans with type 2 diabetes. Diabetologia 2017, 60, 668-678. [CrossRef]

298. Ali, M.; Bukhari, S.A.; Ali, M.; Lee, H.W. Upstream signalling of mTORC1 and its hyperactivation in type 2 diabetes (T2D). BMB Rep. 2017, 50, 601-609. [CrossRef]

299. Ardestani, A.; Lupse, B.; Kido, Y.; Leibowitz, G.; Maedler, K. mTORC1 signaling: A double-edged sword in diabetic $\beta$ cells. Cell Metab. 2018, 27, 314-331. [CrossRef]

300. Guillén, C.; Benito, M. mTORC1 overactivation as a key aging factor in the progression to type 2 diabetes mellitus. Front. Endocrinol. 2018, 9, 621. [CrossRef] [PubMed]

301. Jaafar, R.; Tran, S.; Shah, A.N.; Sun, G.; Valdearcos, M.; Marchetti, P.; Masini, M.; Swisa, A.; Giacometti, S.; Bernal-Mizrachi, E.; et al. mTORC1 to AMPK switching underlies $\beta$-cell metabolic plasticity during maturation and diabetes. J. Clin. Invest. 2019, 129, 4124-4137. [CrossRef]

302. Melnik, B.C. Milk exosomal miRNAs: Potential drivers of AMPK-to-mTORC1 switching in $\beta$-cell de-differentiation of type 2 diabetes mellitus. Nutr. Metab. 2019, 16, 85. [CrossRef] [PubMed]

303. Melnik, B.C.; Schmitz, G. Metformin: An inhibitor of mTORC1 signaling. J. Endocrinol. Diabetes. Obes. $2014,2,1029$.

304. Riera-Borrull, M.; García-Heredia, A.; Fernández-Arroyo, S.; Hernández-Aguilera, A.; Cabré, N.; Cuyàs, E.; Luciano-Mateo, F.; Camps, J.; Menendez, J.A.; Joven, J. Metformin potentiates the benefits of dietary restraint: A metabolomic study. Int. J. Mol. Sci. 2017, 18, 2263. [CrossRef]

305. Zhao, M.; Li, X.W.; Chen, Z.; Hao, F.; Tao, S.X.; Yu, H.Y.; Cheng, R.; Liu, H. Neuroprotective role of metformin in patients with acute stroke and type 2 diabetes mellitus via AMPK/mammalian target of rapamycin (mTOR) signaling pathway and oxidative Stress. Med. Sci. Monit. 2019, 25, 2186-2194. [CrossRef]

306. De Candia, P.; Spinetti, G.; Specchia, C.; Sangalli, E.; La Sala, L.; Uccellatore, A.; Lupini, S.; Genovese, S.; Matarese, G.; Ceriello, A. A unique plasma microRNA profile defines type 2 diabetes progression. PLoS ONE 2017, 12, e0188980. [CrossRef]

307. Lu, W.; Chen, H.; Niu, Y.; Wu, H.; Xia, D.; Wu, Y. Dairy products intake and cancer mortality risk: A meta-analysis of 11 population-based cohort studies. Nutr. J. 2016, 15, 91. [CrossRef] [PubMed]

308. Torfadottir, J.E.; Steingrimsdottir, L.; Mucci, L.; Aspelund, T.; Kasperzyk, J.L.; Olafsson, O.; Fall, K.; Tryggvadottir, L.; Harris, T.B.; Launer, L.; et al. Milk intake in early life and risk of advanced prostate cancer. Am. J. Epidemiol. 2012, 175, 144-153. [CrossRef] 
309. Ruan, W.; Powell-Braxton, L.; Kopchick, J.J.; Kleinberg, D.L. Evidence that insulin-like growth factor I and growth hormone are required for prostate gland development. Endocrinology 1999, 140, 1984-1989. [CrossRef]

310. Ghosh, S.; Lau, H.; Simons, B.W.; Powell, J.D.; Meyers, D.J.; De Marzo, A.M.; Berman, D.M.; Lotan, T.L. PI3K/mTOR signaling regulates prostatic branching morphogenesis. Dev. Biol. 2011, 360, 329-342. [CrossRef]

311. Hsieh, A.C.; Liu, Y.; Edlind, M.P.; Ingolia, N.T.; Janes, M.R.; Sher, A.; Shi, E.Y.; Stumpf, C.R.; Christensen, C.; Bonham, M.J.; et al The translational landscape of mTOR signalling steers cancer initiation and metastasis. Nature 2012, 485, 55-61. [CrossRef]

312. Melnik, B.C.; John, S.M.; Carrera-Bastos, P.; Cordain, L. The impact of cow's milk-mediated mTORC1-signaling in the initiation and progression of prostate cancer. Nutr. Metab. 2012, 9, 74. [CrossRef] [PubMed]

313. Edlind, M.P.; Hsieh, A.C. PI3K-AKT-mTOR signaling in prostate cancer progression and androgen deprivation therapy resistance. Asian, J. Androl. 2014, 16, 378-386.

314. Harrison, S.; Lennon, R.; Holly, J.; Higgins, J.P.T.; Gardner, M.; Perks, C.; Gaunt, T.; Tan, V.; Borwick, C.; Emmet, P.; et al. Does milk intake promote prostate cancer initiation or progression via effects on insulin-like growth factors (IGFs)? A systematic review and meta-analysis. Cancer Causes Control 2017, 28, 497-528. [CrossRef]

315. Zabala-Letona, A.; Arruabarrena-Aristorena, A.; Martín-Martín, N.; Fernandez-Ruiz, S.; Sutherland, J.D.; Clasquin, M.; TomasCortazar, J.; Jimenez, J.; Torres, I.; Quang, P.; et al. mTORC1-dependent AMD1 regulation sustains polyamine metabolism in prostate cancer. Nature 2017, 547, 109-113. [CrossRef]

316. Ahearn, T.U.; Peisch, S.; Pettersson, A.; Ebot, E.M.; Zhou, C.K.; Graff, R.E.; Sinnott, J.A.; Fazli, L.; Judson, G.L.; Bismar, T.A.; et al Expression of IGF/insulin receptor in prostate cancer tissue and progression to lethal disease. Carcinogenesis 2018, 39, 1431-1437. [CrossRef]

317. Audet-Walsh, É.; Vernier, M.; Yee, T.; Laflamme, C.; Li, S.; Chen, Y.; Giguère, V. SREBF1 activity is regulated by an AR/mTOR nuclear axis in prostate cancer. Mol. Cancer Res. 2018, 16, 1396-1405. [CrossRef]

318. Downer, M.K.; Batista, J.L.; Mucci, L.A.; Stampfer, M.J.; Epstein, M.M.; Håkansson, N.; Wolk, A.; Johansson, J.E.; Andrén, O.; Fall, K.; et al. Dairy intake in relation to prostate cancer survival. Int. J. Cancer 2017, 140, 2060-2069. [CrossRef] [PubMed]

319. Tat, D.; Kenfield, S.A.; Cowan, J.E.; Broering, J.M.; Carroll, P.R.; Van Blarigan, E.L.; Chan, J.M. Milk and other dairy foods in relation to prostate cancer recurrence: Data from the cancer of the prostate strategic urologic research endeavor (CaPSURE $\left.{ }^{\mathrm{TM}}\right)$. Prostate 2018, 78, 32-39. [CrossRef] [PubMed]

320. Dybos, S.A.; Flatberg, A.; Halgunset, J.; Viset, T.; Rolfseng, T.; Kvam, S.; Skogseth, H. Increased levels of serum miR-148a-3p are associated with prostate cancer. APMIS 2018, 126, 722-731. [CrossRef] [PubMed]

321. Murata, T.; Takayama, K.; Katayama, S.; Urano, T.; Horie-Inoue, K.; Ikeda, K.; Takahashi, S.; Kawazu, C.; Hasegawa, A.; Ouchi, Y.; et al. miR-148a is an androgen-responsive microRNA that promotes LNCaP prostate cell growth by repressing its target CAND1 expression. Prostate Cancer Prostatic Dis. 2010, 13, 356-361. [CrossRef] [PubMed]

322. Salon, C.; Brambilla, E.; Brambilla, C.; Lantuejoul, S.; Gazzeri, S.; Eymin, B. Altered pattern of Cul-1 protein expression and neddylation in human lung tumours: Relationships with CAND1 and cyclin E protein levels. J. Pathol. 2007, 213, 303-310. [CrossRef] [PubMed]

323. Di Cristofano, A.; De Acetis, M.; Koff, A.; Cordon-Cardo, C.; Pandolfi, P.P. Pten and p27KIP1 cooperate in prostate cancer tumor suppression in the mouse. Nat. Genet. 2001, 27, 222-224. [CrossRef] [PubMed]

324. Hamilton, M.P.; Rajapakshe, K.I.; Bader, D.A.; Cerne, J.Z.; Smith, E.A.; Coarfa, C.; Hartig, S.M.; McGuire, S.E. The landscape of microRNA targeting in prostate cancer defined by AGO-PAR-CLIP. Neoplasia 2016, 18, 356-370. [CrossRef]

325. Valdez, C.D.; Davis, J.N.; Odeh, H.M.; Layfield, T.L.; Cousineau, C.S.; Berton, T.R.; Johnson, D.G.; Wojno, K.J.; Day, M.L. Repression of androgen receptor transcription through the E2F1/DNMT1 axis. PLoS ONE 2011, 6, e25187. [CrossRef]

326. Lee, E.; Wang, J.; Yumoto, K.; Jung, Y.; Cackowski, F.C.; Decker, A.M.; Li, Y.; Franceschi, R.T.; Pienta, K.J.; Taichman, R.S. DNMT1 regulates epithelial-mesenchymal transition and cancer stem cells, which promotes prostate cancer metastasis. Neoplasia 2016, 18, 553-566. [CrossRef]

327. Zadra, G.; Priolo, C.; Patnaik, A.; Loda, M. New strategies in prostate cancer: Targeting lipogenic pathways and the energy sensor AMPK. Clin. Cancer Res. 2010, 16, 3322-3328. [CrossRef]

328. Ahn, H.K.; Lee, Y.H.; Koo, K.C. Current status and application of metformin for prostate cancer: A comprehensive review. Int. J. Mol. Sci. 2020, 21, 8540. [CrossRef]

329. Wang, Y.; Zeng, G.; Jiang, Y. The emerging roles of miR-125b in cancers. Cancer Manag. Res. 2020, 12, 1079-1088. [CrossRef]

330. Ozen, M.; Creighton, C.J.; Ozdemir, M.; Ittmann, M. Widespread deregulation of microRNA expression in human prostate cancer. Oncogene 2008, 27, 1788-1793. [CrossRef]

331. Shi, X.B.; Xue, L.; Yang, J.; Ma, A.H.; Zhao, J.; Xu, M.; Tepper, C.G.; Evans, C.P.; Kung, H.J.; de Vere White, R.W. An androgenregulated miRNA suppresses Bak1 expression and induces androgen-independent growth of prostate cancer cells. Proc. Natl. Acad. Sci. USA 2007, 104, 19983-19988. [CrossRef]

332. Shi, X.B.; Xue, L.; Ma, A.H.; Tepper, C.G.; Kung, H.J.; White, R.W. miR-125b promotes growth of prostate cancer xenograft tumor through targeting pro-apoptotic genes. Prostate 2011, 71, 538-549. [CrossRef] [PubMed]

333. Amir, S.; Ma, A.H.; Shi, X.B.; Xue, L.; Kung, H.J.; Devere White, R.W. Oncomir miR-125b suppresses p14(ARF) to modulate p53-dependent and p53-independent apoptosis in prostate cancer. PLoS ONE 2013, 8, e61064. [CrossRef] [PubMed]

334. Li, T.; Li, D.; Sha, J.; Sun, P.; Huang, Y. MicroRNA-21 directly targets MARCKS and promotes apoptosis resistance and invasion in prostate cancer cells. Biochem. Biophys. Res. Commun. 2009, 383, 280-285. [CrossRef] [PubMed] 
335. Pang, Y.; Young, C.Y.; Yuan, H. MicroRNAs and prostate cancer. Acta Biochim. Biophys. Sin. 2010, 42, 363-369. [CrossRef] [PubMed]

336. Folini, M.; Gandellini, P.; Longoni, N.; Profumo, V.; Callari, M.; Pennati, M.; Colecchia, M.; Supino, R.; Veneroni, S.; Salvioni, R.; et al. miR-21: An oncomir on strike in prostate cancer. Mol. Cancer 2010, 9, 12. [CrossRef]

337. Reis, S.T.; Pontes-Junior, J.; Antunes, A.A.; Dall’Oglio, M.F.; Dip, N.; Passerotti, C.C.; Rossini, G.A.; Morais, D.R.; Nesrallah, A.J.; Piantino, C.; et al. miR-21 may acts as an oncomir by targeting RECK, a matrix metalloproteinase regulator, in prostate cancer. BMC Urol. 2012, 12, 14. [CrossRef]

338. Mishra, S.; Lin, C.L.; Huang, T.H.; Bouamar, H.; Sun, L.Z. MicroRNA-21 inhibits p57Kip2 expression in prostate cancer. Mol. Cancer 2014, 13, 212. [CrossRef]

339. Mishra, S.; Deng, J.J.; Gowda, P.S.; Rao, M.K.; Lin, C.L.; Chen, C.L.; Huang, T.; Sun, L.Z. Androgen receptor and microRNA-21 axis downregulates transforming growth factor beta receptor II (TGFBR2) expression in prostate cancer. Oncogene 2014, 33, 4097-4106. [CrossRef]

340. Huang, W.; Kang, X.L.; Cen, S.; Wang, Y.; Chen, X. High-level expression of microRNA-21 in peripheral blood mononuclear cells is a diagnostic and prognostic marker in prostate cancer. Genet. Test Mol. Biomarkers 2015, 19, 469-475. [CrossRef]

341. Porzycki, P.; Ciszkowicz, E.; Semik, M.; Tyrka, M. Combination of three miRNA (miR-141, miR-21, and miR-375) as potential diagnostic tool for prostate cancer recognition. Int. Urol. Nephrol. 2018, 50, 1619-1626. [CrossRef]

342. Kumar, B.; Rosenberg, A.Z.; Choi, S.M.; Fox-Talbot, K.; De Marzo, A.M.; Nonn, L.; Brennen, W.N.; Marchionni, L.; Halushka, M.K.; Lupold, S.E. Cell-type specific expression of oncogenic and tumor suppressive microRNAs in the human prostate and prostate cancer. Sci. Rep. 2018, 8, 7189. [CrossRef] [PubMed]

343. Guan, C.; Zhang, L.; Wang, S.; Long, L.; Zhou, H.; Qian, S.; Ma, M.; Bai, F.; Meng, Q.H.; Lyu, J. Upregulation of microRNA-21 promotes tumorigenesis of prostate cancer cells by targeting KLF5. Cancer Biol. Ther. 2019, 20, 1149-1161. [CrossRef]

344. Zhou, H.; Zhu, X. MicroRNA-21 and microRNA-30c as diagnostic biomarkers for prostate cancer: A meta-analysis. Cancer Manag. Res. 2019, 11, 2039-2050. [CrossRef] [PubMed]

345. Gaard, M.; Tretli, S.; Løken, E.B. Dietary fat and the risk of breast cancer: A prospective study of 25,892 Norwegian women. Int. J. Cancer 1995, 63, 13-17. [CrossRef] [PubMed]

346. McCann, S.E.; Hays, J.; Baumgart, C.W.; Weiss, E.H.; Yao, S.; Ambrosone, C.B. Usual consumption of specific dairy foods is associated with breast cancer in the Roswell Park Cancer Institute Data Bank and BioRepository. Curr. Dev. Nutr. 2017, 1, e000422. [CrossRef]

347. Fraser, G.E.; Jaceldo-Siegl, K.; Orlich, M.; Mashchak, A.; Sirirat, R.; Knutsen, S. Dairy, soy, and risk of breast cancer: Those confounded milks. Int. J. Epidemiol. 2020, 49, 1526-1537. [CrossRef]

348. Kaluza, J.; Komatsu, S.; Lauriola, M.; Harris, H.R.; Bergkvist, L.; Michaëlsson, K.; Wolk, A. Long-term consumption of nonfermented and fermented dairy products and risk of breast cancer by estrogen receptor status-Population-based prospective cohort study. Clin. Nutr. 2020. Epub ahead of print. [CrossRef] [PubMed]

349. Wang, F.; Yu, L.; Wang, F.; Liu, L.; Guo, M.; Gao, D.; Zhang, Q.; Li, Y.; Li, L.; Fu, Q.; et al. Risk factors for breast cancer in women residing in urban and rural areas of eastern China. J. Int. Med. Res. 2015, 43, 774-789. [CrossRef]

350. Galván-Salazar, H.R.; Arreola-Cruz, A.; Madrigal-Pérez, D.; Soriano-Hernández, A.D.; Guzman-Esquivel, J.; Montes-Galindo, D.A.; López-Flores, R.A.; Espinoza-Gomez, F.; Rodríguez-Sanchez, I.P.; Newton-Sanchez, O.A.; et al. Association of milk and meat consumption with the development of breast cancer in a Western Mexican population. Breast Care 2015, 10, 393-396. [CrossRef] [PubMed]

351. Ronco, A.L.; De Stéfani, E.; Dáttoli, R. Dairy foods and risk of breast cancer: A case-control study in Montevideo, Uruguay. Eur. J. Cancer Prev. 2002, 11, 457-463. [CrossRef]

352. Ji, J.; Sundquist, J.; Sundquist, K. Lactose intolerance and risk of lung, breast and ovarian cancers: Aetiological clues from a population-based study in Sweden. Br. J. Cancer 2015, 112, 149-152. [CrossRef] [PubMed]

353. McCormack, V.A.; dos Santos Silva, I. Breast density and parenchymal patterns as markers of breast cancer risk: A meta-analysis. Cancer Epidemiol. Biomark. Prev. 2006, 15, 1159-1169. [CrossRef]

354. Boyd, N.F.; Guo, H.; Martin, L.J.; Sun, L.; Stone, J.; Fishell, E.; Jong, R.A.; Hislop, G.; Chiarelli, A.; Minkin, S.; et al. Mammographic density and the risk and detection of breast cancer. N. Engl. J. Med. 2007, 356, 227-236. [CrossRef]

355. Yaghjyan, L.; Colditz, G.A.; Collins, L.C.; Schnitt, S.J.; Rosner, B.; Vachon, C.; Tamimi, R.M. Mammographic breast density and subsequent risk of breast cancer in postmenopausal women according to tumor characteristics. J. Natl. Cancer Inst. 2011, 103, 1179-1189. [CrossRef]

356. Pike, M.C.; Krailo, M.D.; Henderson, B.E.; Casagrande, J.T.; Hoel, D.G. 'Hormonal' risk factors, 'breast tissue age' and the age-incidence of breast cancer. Nature 1983, 303, 767-770. [CrossRef]

357. Colditz, G.A.; Frazier, A.L. Models of breast cancer show that risk is set by events of early life: Prevention efforts must shift focus. Cancer Epidemiol. Biomark. Prev. 1995, 4, 567-571.

358. Boyd, N.; Martin, L.; Chavez, S.; Gunasekara, A.; Salleh, A.; Melnichouk, O.; Yaffe, M.; Friedenreich, C.; Minkin, S.; Bronskill, M. Breast-tissue composition and other risk factors for breast cancer in young women: A cross-sectional study. Lancet Oncol. 2009, 10, 569-580. [CrossRef] 
359. Denholm, R.; De Stavola, B.L.; Hipwell, J.H.; Doran, S.J.; Holly, J.M.P.; Folkerd, E.; Dowsett, M.; Leach, M.O.; Hawkes, D.J.; Dos-Santos-Silva, I. Circulating growth and sex hormone levels and breast tissue composition in young nulliparous women. Cancer Epidemiol. Biomarkers Prev. 2018, 27, 1500-1508. [CrossRef]

360. Gaskins, A.J.; Pereira, A.; Quintiliano, D.; Shepherd, J.A.; Uauy, R.; Corvalán, C.; Michels, K.B. Dairy intake in relation to breast and pubertal development in Chilean girls. Am. J. Clin. Nutr. 2017, 105, 1166-1175. [CrossRef]

361. Maruyama, K.; Oshima, T.; Ohyama, K. Exposure to exogenous estrogen through intake of commercial milk produced from pregnant cows. Pediatr. Int. 2010, 52, 33-38. [CrossRef]

362. Kaaks, R.; Johnson, T.; Tikk, K.; Sookthai, D.; Tjønneland, A.; Roswall, N.; Overvad, K.; Clavel-Chapelon, F.; Boutron-Ruault, M.C.; Dossus, L.; et al. Insulin-like growth factor I and risk of breast cancer by age and hormone receptor status-A prospective study within the EPIC cohort. Int. J. Cancer. 2014, 134, 2683-2690. [CrossRef]

363. Samoli, E.; Lagiou, A.; Zourna, P.; Barbouni, A.; Georgila, C.; Tsikkinis, A.; Vassilarou, D.; Minaki, P.; Sfikas, C.; Spanos, E.; et al. Expression of estrogen receptors in non-malignant mammary tissue modifies the association between insulin-like growth factor 1 and breast cancer risk. Ann. Oncol. 2015, 26, 793-797. [CrossRef]

364. Ciruelos Gil, E.M. Targeting the PI3K/AKT/mTOR pathway in estrogen receptor-positive breast cancer. Cancer Treat. Rev. 2014, 40, 862-871. [CrossRef]

365. Guerrero-Zotano, A.; Mayer, I.A.; Arteaga, C.L. PI3K/AKT/mTOR: Role in breast cancer progression, drug resistance, and treatment. Cancer Metastasis Rev. 2016, 35, 515-524. [CrossRef]

366. Sharma, V.R.; Gupta, G.K.; Sharma, A.K.; Batra, N.; Sharma, D.K.; Joshi, A.; Sharma, A.K. PI3K/Akt/mTOR intracellular pathway and breast cancer: Factors, mechanism and regulation. Curr. Pharm. Des. 2017, 23, 1633-1638. [CrossRef]

367. Hare, S.H.; Harvey, A.J. mTOR function and therapeutic targeting in breast cancer. Am. J. Cancer Res. 2017, 7, 383-404.

368. Araki, K.; Miyoshi, Y. Mechanism of resistance to endocrine therapy in breast cancer: The important role of PI3K/Akt/mTOR in estrogen receptor-positive, HER2-negative breast cancer. Breast Cancer 2018, 25, 392-401. [CrossRef]

369. Butt, G.; Shahwar, D.; Qureshi, M.Z.; Attar, R.; Akram, M.; Birinci, Y.; Karatoprak, G.S.; Gasparri, M.L.; Farooqi, A.A. Role of mTORC1 and mTORC2 in breast cancer: Therapeutic targeting of mTOR and its partners to overcome metastasis and drug resistance. Adv. Exp. Med. Biol. 2019, 1152, 283-292.

370. Faria, J.; Negalha, G.; Azevedo, A.; Martel, F. Metformin and breast cancer: Molecular targets. J. Mammary Gland Biol. Neoplasia 2019, 24, 111-123. [CrossRef]

371. Chen, J.; Ou, Y.; Yang, Y.; Li, W.; Xu, Y.; Xie, Y.; Liu, Y. KLHL22 activates amino-acid-dependent mTORC1 signalling to promote tumorigenesis and ageing. Nature 2018, 557, 585-589. [CrossRef]

372. Torres, A.S.; Holz, M.K. Unraveling the multifaceted nature of the nuclear function of mTOR. Biochim. Biophys. Acta Mol. Cell Res. 2021, 1868, 118907. [CrossRef] [PubMed]

373. Alayev, A.; Salamon, R.S.; Berger, S.M.; Schwartz, N.S.; Cuesta, R.; Snyder, R.B.; Holz, M.K. mTORC1 directly phosphorylates and activates ER $\alpha$ upon estrogen stimulation. Oncogene 2016, 35, 3535-3543. [CrossRef] [PubMed]

374. Yamnik, R.L.; Holz, M.K. mTOR/S6K1 and MAPK/RSK signaling pathways coordinately regulate estrogen receptor alpha serine 167 phosphorylation. FEBS Lett. 2010, 584, 124-128. [CrossRef]

375. Yamnik, R.L.; Digilova, A.; Davis, D.C.; Brodt, Z.N.; Murphy, C.J.; Holz, M.K. S6 kinase 1 regulates estrogen receptor alpha in control of breast cancer cell proliferation. J. Biol. Chem. 2009, 284, 6361-6399. [CrossRef]

376. Bostner, J.; Alayev, A.; Berman, A.Y.; Fornander, T.; Nordenskjöld, B.; Holz, M.K.; Stål, O. Raptor localization predicts prognosis and tamoxifen response in estrogen receptor-positive breast cancer. Breast Cancer Res. Treat. 2018, 168, 17-27. [CrossRef]

377. Maruani, D.M.; Spiegel, T.N.; Harris, E.N.; Shachter, A.S.; Unger, H.A.; Herrero-González, S.; Holz, M.K. Estrogenic regulation of S6K1 expression creates a positive regulatory loop in control of breast cancer cell proliferation. Oncogene 2012, 31, 5073-5080 [CrossRef]

378. Cuesta, R.; Berman, A.Y.; Alayev, A.; Holz, M.K. Estrogen receptor $\alpha$ promotes protein synthesis by fine-tuning the expression of the eukaryotic translation initiation factor 3 subunit $\mathrm{f}$ (eIF3f). J. Biol. Chem. 2019, 294, 2267-2278. [CrossRef] [PubMed]

379. Lanzino, M.; Morelli, C.; Garofalo, C.; Panno, M.L.; Mauro, L.; Andò, S.; Sisci, D. Interaction between estrogen receptor alpha and insulin/IGF signaling in breast cancer. Curr. Cancer Drug Targets 2008, 8, 597-610. [CrossRef] [PubMed]

380. Hawsawi, Y.; El-Gendy, R.; Twelves, C.; Speirs, V.; Beattie, J. Insulin-like growth factor-Oestradiol crosstalk and mammary gland tumourigenesis. Biochim. Biophys. Acta 2013, 1836, 345-353. [CrossRef] [PubMed]

381. Becker, M.A.; Ibrahim, Y.H.; Cui, X.; Lee, A.V.; Yee, D. The IGF pathway regulates ER $\alpha$ through a S6K1-dependent mechanism in breast cancer cells. Mol. Endocrinol. 2011, 25, 516-528. [CrossRef]

382. Howard, E.W.; Yang, X. microRNA regulation in estrogen receptor-positive breast cancer and endocrine therapy. Biol. Proced. Online 2018, 20, 17. [CrossRef]

383. Xu, Y.; Chao, L.; Wang, J.; Sun, Y. miRNA-148a regulates the expression of the estrogen receptor through DNMT1-mediated DNA methylation in breast cancer cells. Oncol. Lett. 2017, 14, 4736-4740. [CrossRef]

384. Li, Y.; Deng, X.; Zeng, X.; Peng, X. The role of mir-148a in cancer. J. Cancer. 2016, 7, 1233-1241. [CrossRef]

385. Tozlu, S.; Girault, I.; Vacher, S.; Vendrell, J.; Andrieu, C.; Spyratos, F.; Cohen, P.; Lidereau, R.; Bieche, I. Identification of novel genes that co-cluster with estrogen receptor alpha in breast tumor biopsy specimens, using a large-scale real-time reverse transcription-PCR approach. Endocr. Relat. Cancer 2006, 13, 1109-1120. [CrossRef] 
386. Böckers, M.; Paul, N.W.; Efferth, T. Organophosphate ester tri-o-cresyl phosphate interacts with estrogen receptor $\alpha$ in MCF-7 breast cancer cells promoting cancer growth. Toxicol. Appl. Pharmacol. 2020, 395, 114977. [CrossRef] [PubMed]

387. Böckers, M.; Paul, N.W.; Efferth, T. Bisphenolic compounds alter gene expression in MCF-7 cells through interaction with estrogen receptor $\alpha$. Toxicol. Appl. Pharmacol. 2020, 399, 115030. [CrossRef]

388. Salisbury, T.B.; Arthur, S. The regulation and function of the L-type amino acid transporter 1 (LAT1) in cancer. Int. J. Mol. Sci. 2018, 19, 2373. [CrossRef]

389. Shennan, D.B.; Thomson, J.; Gow, I.F.; Travers, M.T.; Barber, M.C. L-leucine transport in human breast cancer cells (MCF-7 and MDA-MB-231): Kinetics, regulation by estrogen and molecular identity of the transporter. Biochim. Biophys. Acta 2004, 1664, 206-216. [CrossRef]

390. Sato, M.; Harada-Shoji, N.; Toyohara, T.; Soga, T.; Itoh, M.; Miyashita, M.; Tada, H.; Amari, M.; Anzai, N.; Furumoto, S.; et al. L-type amino acid transporter 1 is associated with chemoresistance in breast cancer via the promotion of amino acid metabolism. Sci. Rep. 2021, 11, 589. [CrossRef]

391. Alfarsi, L.H.; El-Ansari, R.; Craze, M.L.; Masisi, B.K.; Mohammed, O.J.; Ellis, I.O.; Rakha, E.A.; Green, A.R. Co-expression effect of SLC7A5/SLC3A2 to predict response to endocrine therapy in oestrogen-receptor-positive breast cancer. Int. J. Mol. Sci. 2020, 21, 1407. [CrossRef]

392. Saito, Y.; Li, L.; Coyaud, E.; Luna, A.; Sander, C.; Raught, B.; Asara, J.M.; Brown, M.; Muthuswamy, S.K. LLGL2 rescues nutrient stress by promoting leucine uptake in ER+ breast cancer. Nature 2019, 569, 275-279. [CrossRef]

393. Yu, S.; Zhao, Z.; Sun, L.; Li, P. Fermentation results inq Changes in milk-derived exosomes and different effects on cell growth and survival. J. Agric. Food Chem. 2017, 65, 1220-1228. [CrossRef]

394. Corcoran, C.; Friel, A.M.; Duffy, M.J.; Crown, J.; O’Driscoll, L. Intracellular and extracellular microRNAs in breast cancer. Clin. Chem. 2011, 57, 18-32. [CrossRef] [PubMed]

395. Kuang, Y.; Nie, Y.J. Exploration of the regulatory effect of miR-21 on breast cancer cell line proliferation and invasion as well as the downstream target genes. Asian Pac. J. Trop. Med. 2016, 9, 470-473. [CrossRef] [PubMed]

396. He, K.; Li, W.X.; Guan, D.; Gong, M.; Ye, S.; Fang, Z.; Huang, J.F.; Lu, A. Regulatory network reconstruction of five essential microRNAs for survival analysis in breast cancer by integrating miRNA and mRNA expression datasets. Funct Integr Genomics 2019, 19, 645-658. [CrossRef] [PubMed]

397. Bahrami, A.; Aledavood, A.; Anvari, K.; Hassanian, S.M.; Maftouh, M.; Yaghobzade, A.; Salarzaee, O.; ShahidSales, S.; Avan, A. The prognostic and therapeutic application of microRNAs in breast cancer: Tissue and circulating microRNAs. J. Cell Physiol. 2018, 233, 774-786. [CrossRef] [PubMed]

398. Hannafon, B.N.; Trigoso, Y.D.; Calloway, C.L.; Zhao, Y.D.; Lum, D.H.; Welm, A.L.; Zhao, Z.J.; Blick, K.E.; Dooley, W.C.; Ding, W.Q. Plasma exosome microRNAs are indicative of breast cancer. Breast Cancer Res. 2016, 18, 90. [CrossRef] [PubMed]

399. Wang, M.; Ji, S.; Shao, G.; Zhang, J.; Zhao, K.; Wang, Z.; Wu, A. Effect of exosome biomarkers for diagnosis and prognosis of breast cancer patients. Clin. Transl. Oncol. 2018, 20, 906-911. [CrossRef]

400. Khalighfard, S.; Alizadeh, A.M.; Irani, S.; Omranipour, R. Plasma miR-21, miR-155, miR-10b, and Let-7a as the potential biomarkers for the monitoring of breast cancer patients. Sci. Rep. 2018, 8, 17981. [CrossRef]

401. Santos, J.C.; Lima, N.D.S.; Sarian, L.O.; Matheu, A.; Ribeiro, M.L.; Derchain, S.F.M. Exosome-mediated breast cancer chemoresistance via miR-155 transfer. Sci. Rep. 2018, 8, 829. [CrossRef]

402. Chang, S.; Wang, R.H.; Akagi, K.; Kim, K.A.; Martin, B.K.; Cavallone, L.; Haines, D.C.; Basik, M.; Mai, P.; Poggi, E.; et al. Tumor suppressor BRCA1 epigenetically controls oncogenic microRNA-155. Nat. Med. 2011, 17, 1275-1282. [CrossRef]

403. Gao, S.; Wang, Y.; Wang, M.; Li, Z.; Zhao, Z.; Wang, R.X.; Wu, R.; Yuan, Z.; Cui, R.; Jiao, K.; et al. MicroRNA-155, induced by FOXP3 through transcriptional repression of BRCA1, is associated with tumor initiation in human breast cancer. Oncotarget 2017, 8, 41451-41464. [CrossRef]

404. Martin, E.C.; Rhodes, L.V.; Elliott, S.; Krebs, A.E.; Nephew, K.P.; Flemington, E.K.; Collins-Burow, B.M.; Burow, M.E. microRNA regulation of mammalian target of rapamycin expression and activity controls estrogen receptor function and RAD001 sensitivity. Mol. Cancer 2014, 13, 229. [CrossRef]

405. Yeh, C.H.; Bellon, M.; Nicot, C. FBXW7: A critical tumor suppressor of human cancers. Mol. Cancer 2018, 17, 115. [CrossRef]

406. Jiang, G.; Shi, W.; Fang, H.; Zhang, X. miR 27a promotes human breast cancer cell migration by inducing EMT in a FBXW7 dependent manner. Mol. Med. Rep. 2018, 18, 5417-5426. [CrossRef]

407. Chen, X.; Li, X.Y.; Long, M.; Wang, X.; Gao, Z.W.; Cui, Y.; Ren, J.; Zhang, Z.; Liu, C.; Dong, K.; et al. The FBXW7 tumor suppressor inhibits breast cancer proliferation and promotes apoptosis by targeting MTDH for degradation. Neoplasma 2018, 65, 201-209. [CrossRef]

408. Ding, J.; Zhao, Z.; Song, J.; Luo, B.; Huang, L. MiR-223 promotes the doxorubicin resistance of colorectal cancer cells via regulating epithelial-mesenchymal transition by targeting FBXW7. Acta Biochim. Biophys Sin. 2018, 50, 597-604. [CrossRef]

409. Liu, Z.; Ma, T.; Duan, J.; Liu, X.; Liu, L. MicroRNA-223-induced inhibition of the FBXW7 gene affects the proliferation and apoptosis of colorectal cancer cells via the Notch and Akt/mTOR pathways. Mol. Med. Rep. 2021, 23, 154.

410. Duarte-Salles, T.; Fedirko, V.; Stepien, M.; Trichopoulou, A.; Bamia, C.; Lagiou, P.; Lukanova, A.; Trepo, E.; Overvad, K.; Tjønneland, A.; et al. Dairy products and risk of hepatocellular carcinoma: The European Prospective Investigation into Cancer and Nutrition. Int. J. Cancer 2014, 135, 1662-1672. [CrossRef] [PubMed] 
411. Yang, W.; Sui, J.; Ma, Y.; Simon, T.G.; Chong, D.; Meyerhardt, J.A.; Willett, W.C.; Giovannucci, E.L.; Chan, A.T.; Zhang, X. A prospective study of dairy product intake and the risk of hepatocellular carcinoma in U.S. men and women. Int. J. Cancer 2020, 146, 1241-1249. [CrossRef]

412. Wang, X.J.; Jiang, C.Q.; Zhang, W.S.; Zhu, F.; Jin, Y.L.; Woo, J.; Cheng, K.K.; Lam, T.H.; Xu, L. Milk consumption and risk of mortality from all-cause, cardiovascular disease and cancer in older people. Clin. Nutr. 2020, 39, 3442-3451. [CrossRef] [PubMed]

413. Xu, B.H.; Li, X.X.; Yang, Y.; Zhang, M.Y.; Rao, H.L.; Wang, H.Y.; Zheng, X.F. Aberrant amino acid signaling promotes growth and metastasis of hepatocellular carcinomas through Rab1A-dependent activation of mTORC1 by Rab1A. Oncotarget 2015, 6, 20813-20828. [CrossRef]

414. Ericksen, R.E.; Lim, S.L.; McDonnell, E.; Shuen, W.H.; Vadiveloo, M.; White, P.J.; Ding, Z.; Kwok, R.; Lee, P.; Radda, G.K.; et al. Loss of BCAA catabolism during carcinogenesis enhances mTORC1 activity and promotes tumor development and progression. Cell Metab. 2019, 29, 1151-1165.e6. [CrossRef]

415. Ericksen, R.E.; Han, W. Malignant manipulaTORs of metabolism: Suppressing BCAA catabolism to enhance mTORC1 activity. Mol. Cell Oncol. 2019, 6, 1585171. [CrossRef]

416. Akula, S.M.; Abrams, S.L.; Steelman, L.S.; Emma, M.R.; Augello, G.; Cusimano, A.; Azzolina, A.; Montalto, G.; Cervello, M.; McCubrey, J.A. RAS/RAF/MEK/ERK, PI3K/PTEN/AKT/mTORC1 and TP53 pathways and regulatory miRs as therapeutic targets in hepatocellular carcinoma. Expert Opin. Ther. Targets 2019, 23, 915-929. [CrossRef]

417. Melnik, B.C. Dairy consumption and hepatocellular carcinoma risk. Ann. Transl. Med. 2020. [CrossRef]

418. Wang, H.; Hou, L.; Li, A.; Duan, Y.; Gao, H.; Song, X. Expression of serum exosomal microRNA-21 in human hepatocellular carcinoma. Biomed. Res. Int. 2014, 2014, 864894. [CrossRef]

419. Zhuang, C.; Jiang, W.; Huang, D.; Xu, L.; Yang, Q.; Zheng, L.; Wang, X.; Hu, L. Serum miR-21, miR-26a and miR-101 as potential biomarkers of hepatocellular carcinoma. Clin. Res. Hepatol. Gastroenterol. 2016, 40, 386-396. [CrossRef]

420. Sorop, A.; Iacob, R.; Iacob, S.; Constantinescu, D.; Chitoiu, L.; Fertig, T.E.; Dinischiotu, A.; Chivu-Economescu, M.; Bacalbasa, N.; Savu, L.; et al. Plasma small extracellular vesicles derived miR-21-5p and miR-92a-3p as potential biomarkers for hepatocellular carcinoma screening. Front. Genet. 2020, 11, 712. [CrossRef]

421. Ghosh, S.; Bhowmik, S.; Majumdar, S.; Goswami, A.; Chakraborty, J.; Gupta, S.; Aggarwal, S.; Ray, S.; Chatterjee, R.; Bhattacharyya, S.; et al. The exosome encapsulated microRNAs as circulating diagnostic marker for hepatocellular carcinoma with low alpha-fetoprotein. Int. J. Cancer 2020, 147, 2934-2947. [CrossRef]

422. Fu, X.; Wen, H.; Jing, L.; Yang, Y.; Wang, W.; Liang, X.; Nan, K.; Yao, Y.; Tian, T. MicroRNA-155-5p promotes hepatocellular carcinoma progression by suppressing PTEN through the PI3K/Akt pathway. Cancer Sci. 2017, 108, 620-631. [CrossRef]

423. Matsuura, Y.; Wada, H.; Eguchi, H.; Gotoh, K.; Kobayashi, S.; Kinoshita, M.; Kubo, M.; Hayashi, K.; Iwagami, Y.; Yamada, D.; et al. Exosomal miR-155 derived from hepatocellular carcinoma cells under hypoxia promotes angiogenesis in endothelial cells. Dig. Dis. Sci. 2019, 64, 792-802. [CrossRef] [PubMed]

424. Wang, J.; Li, X.; Zhang, D. Dairy product consumption and risk of non-Hodgkin lymphoma: A meta-analysis. Nutrients 2016, 8 , 120. [CrossRef]

425. Sukswai, N.; Lyapichev, K.; Khoury, J.D.; Medeiros, L.J. Diffuse large B-cell lymphoma variants: An update. Pathology 2020, 52, 53-67. [CrossRef]

426. Ricci, J.E.; Chiche, J. Metabolic reprogramming of non-Hodgkin's B-cell lymphomas and potential therapeutic strategies. Front. Oncol. 2018, 8, 556. [CrossRef] [PubMed]

427. Johnston, P.B.; LaPlant, B.; McPhail, E.; Habermann, T.M.; Inwards, D.J.; Micallef, I.N.; Colgan, J.P.; Nowakowski, G.S.; Ansell, S.M.; Witzig, T.E. Everolimus combined with R-CHOP-21 for new, untreated, diffuse large B-cell lymphoma (NCCTG 1085 [Alliance]): Safety and efficacy results of a phase 1 and feasibility trial. Lancet Haematol. 2016, 3, e309-e316. [CrossRef]

428. Gu, L.; Song, G.; Chen, L.; Nie, Z.; He, B.; Pan, Y.; Xu, Y.; Li, R.; Gao, T.; Cho, W.C.; et al. Inhibition of miR-21 induces biological and behavioral alterations in diffuse large B-cell lymphoma. Acta Haematol. 2013, 130, 87-94. [CrossRef]

429. Go, H.; Jang, J.Y.; Kim, P.J.; Kim, Y.G.; Nam, S.J.; Paik, J.H.; Kim, T.M.; Heo, D.S.; Kim, C.W.; Jeon, Y.K. MicroRNA-21 plays an oncogenic role by targeting FOXO1 and activating the PI3K/AKT pathway in diffuse large B-cell lymphoma. Oncotarget 2015, 6 , 15035-15049. [CrossRef] [PubMed]

430. Song, J.; Shao, Q.; Li, C.; Liu, H.; Li, J.; Wang, Y.; Song, W.; Li, L.; Wang, G.; Shao, Z.; et al. Effects of microRNA-21 on apoptosis by regulating the expression of PTEN in diffuse large B-cell lymphoma. Medicine 2017, 96, e7952. [CrossRef]

431. Liu, K.; Du, J.; Ruan, L. MicroRNA-21 regulates the viability and apoptosis of diffuse large B-cell lymphoma cells by upregulating B cell lymphoma-2. Exp. Ther. Med. 2017, 14, 4489-4496. [CrossRef]

432. Eis, P.S.; Tam, W.; Sun, L.; Chadburn, A.; Li, Z.; Gomez, M.F.; Lund, E.; Dahlberg, J.E. Accumulation of miR-155 and BIC RNA in human B cell lymphomas. Proc. Natl. Acad. Sci. USA 2005, 102, 3627-3632. [CrossRef] [PubMed]

433. Zhu, F.Q.; Zeng, L.; Tang, N.; Tang, Y.P.; Zhou, B.P.; Li, F.F.; Wu, W.G.; Zeng, X.B.; Peng, S.S. MicroRNA-155 downregulation promotes cell cycle arrest and apoptosis in diffuse large B-cell lymphoma. Oncol. Res. 2016, 24, 415-427. [CrossRef]

434. Li, X.D.; Li, X.M.; Gu, J.W.; Sun, X.C. MiR-155 regulates lymphoma cell proliferation and apoptosis through targeting SOCS3/JAKSTAT3 signaling pathway. Eur. Rev. Med. Pharmacol. Sci. 2017, 21, 5153-5159.

435. Larrabeiti-Etxebarria, A.; Lopez-Santillan, M.; Santos-Zorrozua, B.; Lopez-Lopez, E.; Garcia-Orad, A. Systematic review of the potential of microRNAs in diffuse large B cell lymphoma. Cancers 2019, 11, 144. [CrossRef] 
436. Ahmadvand, M.; Eskandari, M.; Pashaiefar, H.; Yaghmaie, M.; Manoochehrabadi, S.; Khakpour, G.; Sheikhsaran, F.; Montazer Zohour, M. Over expression of circulating miR-155 predicts prognosis in diffuse large B-cell lymphoma. Leuk. Res. 2018, 70, 45-48. [CrossRef] [PubMed]

437. Zheng, X.; Rui, H.; Liu, Y.; Dong, J. Proliferation and apoptosis of B-cell lymphoma cells under targeted regulation of FOXO3 by miR-155. Mediterr. J. Hematol. Infect. Dis. 2020, 12, e2020073. [CrossRef] [PubMed]

438. Chen, C.C.; Jeon, S.M.; Bhaskar, P.T.; Nogueira, V.; Sundararajan, D.; Tonic, I.; Park, Y.; Hay, N. FoxOs inhibit mTORC1 and activate Akt by inducing the expression of Sestrin3 and Rictor. Dev. Cell 2010, 18, 592-604. [CrossRef]

439. Hay, N. Interplay between FOXO, TOR, and Akt. Biochim. Biophys. Acta 2011, 1813, 1965-1970. [CrossRef] [PubMed]

440. Kyrozis, A.; Ghika, A.; Stathopoulos, P.; Vassilopoulos, D.; Trichopoulos, D.; Trichopoulou, A. Dietary and lifestyle variables in relation to incidence of Parkinson's disease in Greece. Eur. J. Epidemiol. 2013, 28, 67-77. [CrossRef] [PubMed]

441. Jiang, W.; Ju, C.; Jiang, H.; Zhang, D. Dairy foods intake and risk of Parkinson's disease: A dose-response meta-analysis of prospective cohort studies. Eur. J. Epidemiol. 2014, 29, 613-619. [CrossRef]

442. Bento, C.F.; Ashkenazi, A.; Jimenez-Sanchez, M.; Rubinsztein, D.C. The Parkinson's disease-associated genes ATP13A2 and SYT11 regulate autophagy via a common pathway. Nat. Commun. 2016, 7, 11803. [CrossRef]

443. Olsson, E.; Byberg, L.; Höijer, J.; Kilander, L.; Larsson, S.C. Milk and fermented milk intake and Parkinson's disease: Cohort study. Nutrients 2020, 12, 2763. [CrossRef]

444. Park, M.; Ross, G.W.; Petrovitch, H.; White, L.R.; Masaki, K.H.; Nelson, J.S.; Tanner, C.M.; Curb, J.D.; Blanchette, P.L.; Abbott, R.D Consumption of milk and calcium in midlife and the future risk of Parkinson disease. Neurology 2005, 64, 1047-1051. [CrossRef]

445. Melnik, B.C. Synergistic effects of milk-derived exosomes and galactose on $\alpha$-synuclein pathology in Parkinson's disease and type 2 diabetes mellitus. Int. J. Mol. Sci. 2021, 22, 1059. [CrossRef]

446. Beitz, J.M. Parkinson's disease: A review. Front. Biosci. Schol. Ed. 2014, 6, 65-74. [CrossRef]

447. Armstrong, M.J.; Okun, M.S. Diagnosis and treatment of Parkinson disease: A review. JAMA 2020, 323, 548-560. [CrossRef] [PubMed]

448. Lin, K.J.; Lin, K.L.; Chen, S.D.; Liou, C.W.; Chuang, Y.C.; Lin, H.Y.; Lin, T.K. The overcrowded crossroads: Mitochondria, alpha-synuclein, and the endo-lysosomal system interaction in Parkinson's disease. Int. J. Mol. Sci. 2019, 20, 5312. [CrossRef] [PubMed]

449. Lan, A.P.; Chen, J.; Zhao, Y.; Chai, Z.; Hu, Y. mTOR signaling in Parkinson's disease. Neuromolecular Med. 2017, 19, 1-10. [CrossRef]

450. Hughes, K.C.; Gao, X.; Kim, I.Y.; Wang, M.; Weisskopf, M.G.; Schwarzschild, M.A.; Ascherio, A. Intake of dairy foods and risk of Parkinson disease. Neurology 2017, 89, 46-52. [CrossRef]

451. Zhu, Z.; Yang, C.; Iyaswamy, A.; Krishnamoorthi, S.; Sreenivasmurthy, S.G.; Liu, J.; Wang, Z.; Tong, B.C.; Song, J.; Lu, J.; et al. Balancing mTOR signaling and autophagy in the treatment of Parkinson's disease. Int. J. Mol. Sci. 2019, 20, 728. [CrossRef] [PubMed]

452. Xu, F.; Na, L.; Li, Y.; Chen, L. Roles of the PI3K/AKT/mTOR signalling pathways in neurodegenerative diseases and tumours. Cell Biosci. 2020, 10, 54. [CrossRef] [PubMed]

453. Liddle, R.A. Parkinson's disease from the gut. Brain Res. 2018, 1693, 201-206. [CrossRef] [PubMed]

454. Kim, S.; Kwon, S.H.; Kam, T.I.; Panicker, N.; Karuppagounder, S.S.; Lee, S.; Lee, J.H.; Kim, W.R.; Kook, M.; Foss, C.A.; et al. Transneuronal propagation of pathologic $\alpha$-synuclein from the gut to the brain models Parkinson's disease. Neuron 2019, 103, 627-641. [CrossRef] [PubMed]

455. Holmqvist, S.; Chutna, O.; Bousset, L.; Aldrin-Kirk, P.; Li, W.; Björklund, T.; Wang, Z.Y.; Roybon, L.; Melki, R.; Li, J.Y. Direct evidence of Parkinson pathology spread from the gastrointestinal tract to the brain in rats. Acta Neuropathol. 2014, 128, 805-820 [CrossRef] [PubMed]

456. Bohórquez, D.V.; Liddle, R.A. Axon-like basal processes in enteroendocrine cells: Characteristics and potential targets. Clin. Transl. Sci. 2011, 4, 387-391. [CrossRef] [PubMed]

457. Bohórquez, D.V.; Samsa, L.A.; Roholt, A.; Medicetty, S.; Chandra, R. An enteroendocrine cell-enteric glia connection revealed by 3D electron microscopy. PLoS ONE 2014, 9, e899881. [CrossRef] [PubMed]

458. Latorre, R.; Sternini, C.; De Giorgio, R.; Greenwood-Van Meerveld, B. Enteroendocrine cells: A review of their role in brain-gut communication. Neurogastroenterol. Motil. 2016, 28, 620-630. [CrossRef]

459. Borghammer, P. How does Parkinson's disease begin? Perspectives on neuroanatomical pathways, prions, and histology. Mov. Disord. 2018, 33, 48-57. [CrossRef]

460. Boulos, C.; Yaghi, N.; El Hayeck, R.; Heraoui, G.N.; Fakhoury-Sayegh, N. Nutritional risk factors, microbiota and Parkinson's disease: What is the current evidence? Nutrients 2019, 11, 1896. [CrossRef]

461. Li, Y.F.; Ouyang, S.H.; Tu, L.F.; Wang, X.; Yuan, W.L.; Wang, G.E.; Wu, Y.P.; Duan, W.J.; Yu, H.M.; Fang, Z.Z.; et al. Caffeine protects skin from oxidative stress-induced senescence through the activation of autophagy. Theranostics 2018, 8, 5713-5730. [CrossRef] [PubMed]

462. Saiki, S.; Sasazawa, Y.; Imamichi, Y.; Kawajiri, S.; Fujimaki, T.; Tanida, I.; Kobayashi, H.; Sato, F.; Sato, S.; Ishikawa, K.; et al. Caffeine induces apoptosis by enhancement of autophagy via PI3K/Akt/mTOR/p70S6K inhibition. Autophagy 2011, 7, 176-187. [CrossRef] [PubMed] 
463. Prasanth, M.I.; Sivamaruthi, B.S.; Chaiyasut, C.; Tencomnao, T. A review of the role of green tea (Camellia sinensis) in antiphotoaging, stress resistance, neuroprotection, and autophagy. Nutrients 2019, 11, 474. [CrossRef]

464. Limanaqi, F.; Biagioni, F.; Busceti, C.L.; Ryskalin, L.; Polzella, M.; Frati, A.; Fornai, F. Phytochemicals bridging autophagy induction and alpha-synuclein degradation in parkinsonism. Int. J. Mol. Sci. 2019, 20, 3274. [CrossRef] [PubMed]

465. Xiao, X.; Shang, X.; Zhai, B.; Zhang, H.; Zhang, T. Nicotine alleviates chronic stress-induced anxiety and depressive-like behavior and hippocampal neuropathology via regulating autophagy signaling. Neurochem. Int. 2018, 114, 58-70. [CrossRef] [PubMed]

466. Ni, H.; Xu, S.; Chen, H.; Dai, Q. Nicotine modulates CTSS (cathepsin S) synthesis and secretion through regulating the autophagylysosomal machinery in atherosclerosis. Arterioscler. Thromb. Vasc. Biol. 2020, 40, 2054-2069. [CrossRef]

467. Kim, J.; Kundu, M.; Viollet, B.; Guan, K.L. AMPK and mTOR regulate autophagy through direct phosphorylation of Ulk1. Nat. Cell Biol. 2011, 13, 132-141. [CrossRef]

468. Matsumoto, L.; Takuma, H.; Tamaoka, A.; Kurisaki, H.; Date, H.; Tsuji, S.; Iwata, A. CpG demethylation enhances alpha-synuclein expression and affects the pathogenesis of Parkinson's disease. PLoS ONE 2010, 5, e15522. [CrossRef] [PubMed]

469. Wang, Y.; Wang, X.; Li, R.; Yang, Z.F.; Wang, Y.Z.; Gong, X.L.; Wang, X.M. A DNA methyltransferase inhibitor, 5-aza-2'deoxycytidine, exacerbates neurotoxicity and upregulates Parkinson's disease-related genes in dopaminergic neurons. CNS Neurosci. Ther. 2013, 19, 183-190. [CrossRef] [PubMed]

470. Jiang, W.; Li, J.; Zhang, Z.; Wang, H.; Wang, Z. Epigenetic upregulation of alpha-synuclein in the rats exposed to methamphetamine. Eur. J. Pharmacol. 2014, 745, 243-248. [CrossRef]

471. Müller, T.; Kohlhepp, W. Hypomethylation in Parkinson's disease: An epigenetic drug effect? Mov. Disord. 2016, 31 , 605. [CrossRef]

472. Guhathakurta, S.; Bok, E.; Evangelista, B.A.; Kim, Y.S. Deregulation of $\alpha$-synuclein in Parkinson's disease: Insight from epige-netic structure and transcriptional regulation of SNCA. Prog. Neurobiol. 2017, 154, 21-36. [CrossRef] [PubMed]

473. Zhao, Q.; Liu, H.; Cheng, J.; Zhu, Y.; Xiao, Q.; Bai, Y.; Tao, J. Neuroprotective effects of lithium on a chronic MPTP mouse model of Parkinson's disease via regulation of $\alpha$ synuclein methylation. Mol. Med. Rep. 2019, 19, 4989-4997. [CrossRef] [PubMed]

474. Park, J.M.; Jung, C.H.; Seo, M.; Otto, N.M.; Grunwald, D.; Kim, K.H.; Moriarity, B.; Kim, Y.M.; Starker, C.; Nho, R.S.; et al. The ULK1 complex mediates MTORC1 signaling to the autophagy initiation machinery via binding and phosphorylating ATG14. Autophagy 2016, 12, 547-564. [CrossRef]

475. Noda, T. Regulation of Autophagy through TORC1 and mTORC1. Biomolecules 2017, 7, 52. [CrossRef]

476. Rabanal-Ruiz, Y.; Otten, E.G.; Korolchuk, V.I. mTORC1 as the main gateway to autophagy. Essays Biochem. 2017, 61, 565-584.

477. Alvarez-Erviti, L.; Seow, Y.; Schapira, A.H.; Rodriguez-Oroz, M.C.; Obeso, J.A.; Cooper, J.M. Influence of microRNA deregula-tion on chaperone-mediated autophagy and $\alpha$-synuclein pathology in Parkinson's disease. Cell Death Dis. 2013, 4, e545. [CrossRef]

478. Su, C.; Yang, X.; Lou, J. Geniposide reduces $\alpha$-synuclein by blocking microRNA-21/lysosome-associated membrane protein 2A interaction in Parkinson disease models. Brain Res. 2016, 1644, 98-106. [CrossRef]

479. Lee, J.; Fu, Z.; Chung, M.; Jang, D.J.; Lee, H.J. Role of milk and dairy intake in cognitive function in older adults: A systematic review and meta-analysis. Nutr. J. 2018, 17, 82. [CrossRef] [PubMed]

480. Kesse-Guyot, E.; Assmann, K.E.; Andreeva, V.A.; Ferry, M.; Hercberg, S.; Galan, P.; SU.VI.MAX 2 Research Group. Consumption of dairy products and cognitive functioning: Findings from the SU.VI.MAX 2 study. J. Nutr. Health Aging 2016, 20 , 128-137. [CrossRef]

481. Petruski-Ivleva, N.; Kucharska-Newton, A.; Palta, P.; Couper, D.; Meyer, K.; Graff, M.; Haring, B.; Sharrett, R.; Heiss, G. Milk intake at midlife and cognitive decline over 20 years. The Atherosclerosis Risk in Communities (ARIC) study. Nutrients 2017, 9 , 1134. [CrossRef] [PubMed]

482. Cuesta-Triana, F.; Verdejo-Bravo, C.; Fernández-Pérez, C.; Martín-Sánchez, F.J. Effect of milk and other dairy products on the risk of frailty, sarcopenia, and cognitive performance decline in the elderly: A systematic review. Adv. Nutr. 2019, 10 (Suppl. 2), S105-S119. [CrossRef]

483. Soria Lopez, J.A.; González, H.M.; Léger, G.C. Alzheimer's disease. Handb. Clin. Neurol. 2019, 167, 231-255. [PubMed]

484. Serý, O.; Povová, J.; Míšek, I.; Pešák, L.; Janout, V. Molecular mechanisms of neuropathological changes in Alzheimer's disease: A review. Folia Neuropathol. 2013, 51, 1-9. [CrossRef] [PubMed]

485. Lane, C.A.; Hardy, J.; Schott, J.M. Alzheimer's disease. Eur. J. Neurol. 2018, 25, 59-70. [CrossRef]

486. Hernández, F.; Llorens-Martín, M.; Bolós, M.; Pérez, M.; Cuadros, R.; Pallas-Bazarra, N.; Zabala, J.C.; Avila, J. New beginnings in Alzheimer's disease: The most prevalent tauopathy. J. Alzheimers Dis. 2018, 64, S529-S534. [CrossRef] [PubMed]

487. Chong, F.P.; Ng, K.Y.; Koh, R.Y.; Chye, S.M. Tau proteins and tauopathies in Alzheimer's disease. Cell Mol. Neurobiol. 2018, 38, 965-980. [CrossRef] [PubMed]

488. Alonso, A.C.; Grundke-Iqbal, I.; Iqbal, K. Alzheimer's disease hyperphosphorylated tau sequesters normal tau into tangles of filaments and disassembles microtubules. Nat. Med. 1996, 2, 783-787. [CrossRef]

489. Calabrò, M.; Rinaldi, C.; Santoro, G.; Crisafulli, C. The biological pathways of Alzheimer disease: A review. AIMS Neurosci. 2020, 8, 86-132. [CrossRef]

490. Neddens, J.; Temmel, M.; Flunkert, S.; Kerschbaumer, B.; Hoeller, C.; Loeffler, T.; Niederkofler, V.; Daum, G.; Attems, J.; HutterPaier, B. Phosphorylation of different tau sites during progression of Alzheimer's disease. Acta Neuropathol. Commun. 2018,6 , 52. [CrossRef] 
491. Tang, Z.; Bereczki, E.; Zhang, H.; Wang, S.; Li, C.; Ji, X.; Branca, R.M.; Lehtiö, J.; Guan, Z.; Filipcik, P.; et al. Mammalian target of rapamycin (mTor) mediates tau protein dyshomeostasis: Implication for Alzheimer disease. J. Biol. Chem. 2013, 288, 15556-15570. [CrossRef]

492. Caccamo, A.; Magrì, A.; Medina, D.X.; Wisely, E.V.; López-Aranda, M.F.; Silva, A.J.; Oddo, S. mTOR regulates tau phosphorylation and degradation: Implications for Alzheimer's disease and other tauopathies. Aging Cell 2013, 12, 370-380. [CrossRef]

493. Tang, Z.; Baykal, A.T.; Gao, H.; Quezada, H.C.; Zhang, H.; Bereczki, E.; Serhatli, M.; Baykal, B.; Acioglu, C.; Wang, S.; et al. mTor is a signaling hub in cell survival: A mass-spectrometry-based proteomics investigation. J. Proteome Res. 2014, 13, 2433-2444. [CrossRef] [PubMed]

494. Tang, Z.; Ioja, E.; Bereczki, E.; Hultenby, K.; Li, C.; Guan, Z.; Winblad, B.; Pei, J.J. mTor mediates tau localization and secretion: Implication for Alzheimer's disease. Biochim. Biophys. Acta. 2015, 1853, 1646-1657. [CrossRef] [PubMed]

495. Mueed, Z.; Tandon, P.; Maurya, S.K.; Deval, R.; Kamal, M.A.; Poddar, N.K. Tau and mTOR: The hotspots for multifarious diseases in Alzheimer's development. Front Neurosci. 2019, 12, 1017. [CrossRef]

496. Norambuena, A.; Wallrabe, H.; Cao, R.; Wang, D.B.; Silva, A.; Svindrych, Z.; Periasamy, A.; Hu, S.; Tanzi, R.E.; Kim, D.Y.; et al. A novel lysosome-to-mitochondria signaling pathway disrupted by amyloid- $\beta$ oligomers. EMBO J. 2018, 37, e100241. [CrossRef] [PubMed]

497. Polanco, J.C.; Götz, J. Are you TORCing tau me? Amyloid- $\beta$ blocks the conversation between lysosomes and mitochondria. EMBO J. 2018, 37, e100839. [CrossRef]

498. Zhu, X.C.; Yu, J.T.; Jiang, T.; Tan, L. Autophagy modulation for Alzheimer's disease therapy. Mol. Neurobiol. 2013, 48, 702-714. [CrossRef]

499. Li, Q.; Liu, Y.; Sun, M. Autophagy and Alzheimer's disease. Cell Mol. Neurobiol. 2017, 37, 377-388. [CrossRef]

500. Silva, M.C.; Nandi, G.A.; Tentarelli, S.; Gurrell, I.K.; Jamier, T.; Lucente, D.; Dickerson, B.C.; Brown, D.G.; Brandon, N.J.; Haggarty, S.J. Prolonged tau clearance and stress vulnerability rescue by pharmacological activation of autophagy in tauopathy neurons. Nat. Commun. 2020, 11, 3258. [CrossRef]

501. Ulland, T.K.; Song, W.M.; Huang, S.C.; Ulrich, J.D.; Sergushichev, A.; Beatty, W.L.; Loboda, A.A.; Zhou, Y.; Cairns, N.J.; Kambal, A.; et al. TREM2 maintains microglial metabolic fitness in Alzheimer's disease. Cell 2017, 170, 649-663. [CrossRef] [PubMed]

502. Guo, T.; Noble, W.; Hanger, D.P. Roles of tau protein in health and disease. Acta Neuropathol. 2017, 133, 665-704. [CrossRef] [PubMed]

503. Hanger, D.P.; Goniotaki, D.; Noble, W. Synaptic localisation of tau. Adv. Exp. Med. Biol. 2019, 1184, 105-112. [PubMed]

504. Wang, Y.; Mandelkow, E. Tau in physiology and pathology. Nat. Rev. Neurosci. 2016, 17, 5-21. [CrossRef] [PubMed]

505. Coupland, K.G.; Kim, W.S.; Halliday, G.M.; Hallupp, M.; Dobson-Stone, C.; Kwok, J.B. Effect of PSEN1 mutations on MAPT methylation in early-onset Alzheimer's disease. Curr. Alzheimer Res. 2015, 12, 745-751. [CrossRef] [PubMed]

506. Iwata, A.; Nagata, K.; Hatsuta, H.; Takuma, H.; Bundo, M.; Iwamoto, K.; Tamaoka, A.; Murayama, S.; Saido, T.; Tsuji, S. Altered CpG methylation in sporadic Alzheimer's disease is associated with APP and MAPT dysregulation. Hum. Mol. Genet. 2014, 23 , 648-656. [CrossRef]

507. Coupland, K.G.; Kim, W.S.; Halliday, G.M.; Hallupp, M.; Dobson-Stone, C.; Kwok, J.B. Role of the long non-coding RNA MAPT-AS1 in regulation of microtubule associated protein tau (MAPT) expression in Parkinson's disease. PLoS ONE 2016, 11, e0157924. [CrossRef]

508. Coupland, K.G.; Mellick, G.D.; Silburn, P.A.; Mather, K.; Armstrong, N.J.; Sachdev, P.S.; Brodaty, H.; Huang, Y.; Halliday, G.M.; Hallupp, M.; et al. DNA methylation of the MAPT gene in Parkinson's disease cohorts and modulation by vitamin E in vitro. Mov. Disord. 2014, 29, 1606-1614. [CrossRef]

509. Mutai, E.; Zhou, F.; Zempleni, J. Depletion of dietary bovine milk exosomes impairs sensorimotor gating and spatial learning in C57BL/6 mice. FASEB J. 2018, 31, S1.

510. Cai, Q.; Tammineni, P. Mitochondrial aspects of synaptic dysfunction in Alzheimer's disease. J. Alzheimers Dis. 2017, 57, 1087-1103. [CrossRef] [PubMed]

511. Perez Ortiz, J.M.; Swerdlow, R.H. Mitochondrial dysfunction in Alzheimer's disease: Role in pathogenesis and novel therapeutic opportunities. Br. J. Pharmacol. 2019, 176, 3489-3507. [CrossRef]

512. Guo, L.; Tian, J.; Du, H. Mitochondrial dysfunction and synaptic transmission failure in Alzheimer's disease. J. Alzheimers Dis. 2017, 57, 1071-1086. [CrossRef]

513. Wang, X.; Wang, W.; Li, L.; Perry, G.; Lee, H.G.; Zhu, X. Oxidative stress and mitochondrial dysfunction in Alzheimer's disease. Biochim. Biophys. Acta 2014, 1842, 1240-1247. [CrossRef] [PubMed]

514. Ganguly, G.; Chakrabarti, S.; Chatterjee, U.; Saso, L. Proteinopathy, oxidative stress and mitochondrial dysfunction: Cross talk in Alzheimer's disease and Parkinson's disease. Drug Des. Devel. Ther. 2017, 11, 797-810. [CrossRef]

515. Cenini, G.; Lloret, A.; Cascella, R. Oxidative stress in neurodegenerative diseases: From a mitochondrial point of view. Oxid. Med. Cell Longev. 2019, 2019, 2105607. [CrossRef]

516. Cui, X.; Zuo, P.; Zhang, Q.; Li, X.; Hu, Y.; Long, J.; Packer, L.; Liu, J. Chronic systemic D-galactose exposure induces memory loss, neurodegeneration, and oxidative damage in mice: Protective effects of R-alpha-lipoic acid. J. Neurosci. Res. 2006, 84, 647-654. [CrossRef]

517. Sadigh-Eteghad, S.; Majdi, A.; McCann, S.K.; Mahmoudi, J.; Vafaee, M.S.; Macleod, M.R. D-galactose-induced brain ageing model: A systematic review and meta-analysis on cognitive outcomes and oxidative stress indices. PLoS ONE 2017, 12, e0184122. 
518. Shwe, T.; Pratchayasakul, W.; Chattipakorn, N.; Chattipakorn, S.C. Role of D-galactose-induced brain aging and its potential used for therapeutic interventions. Exp. Gerontol. 2018, 101, 13-36. [CrossRef] [PubMed]

519. Lange, A.; Grønbæk, H.; Vilstrup, H.; Keiding, S. Age-dependency of galactose elimination capacity in healthy children and children with chronic liver disease. Scand. J. Gastroenterol. 2011, 46, 197-200. [CrossRef]

520. Marchesini, G.; Bua, V.; Brunori, A.; Bianchi, G.; Pisi, P.; Fabbri, A.; Zoli, M.; Pisi, E. Galactose elimination capacity and liver volume in aging man. Hepatology 1988, 8, 1079-1083. [CrossRef] [PubMed]

521. Schnegg, M.; Lauterburg, B.H. Quantitative liver function in the elderly assessed by galactose elimination capacity, aminopyrine demethylation and caffeine clearance. J. Hepatol. 1986, 3, 164-171. [CrossRef]

522. Bei, Y.; Wu, X.; Cretoiu, D.; Shi, J.; Zhou, Q.; Lin, S.; Wang, H.; Cheng, Y.; Zhang, H.; Xiao, J.; et al. miR-21 suppression prevents cardiac alterations induced by d-galactose and doxorubicin. J. Mol. Cell Cardiol. 2018, 115, 130-141. [CrossRef] [PubMed]

523. Chen, Z.; Luo, J.; Sun, S.; Cao, D.; Shi, H.; Loor, J.J. miR-148a and miR-17-5p synergistically regulate milk TAG synthesis via PPARGC1A and PPARA in goat mammary epithelial cells. RNA Biol. 2017, 14, 326-338. [CrossRef] [PubMed]

524. Handschin, C.; Spiegelman, B.M. Peroxisome proliferator-activated receptor gamma coactivator 1 coactivators, energy homeostasis, and metabolism. Endocr. Rev. 2006, 27, 728-735. [CrossRef] [PubMed]

525. Schreiber, S.N.; Emter, R.; Hock, M.B.; Knutti, D.; Cardenas, J.; Podvinec, M.; Oakeley, E.J.; Kralli, A. The estrogen-related re-ceptor alpha (ERRalpha) functions in PPARgamma coactivator 1alpha (PGC-1alpha)-induced mitochondrial biogenesis. Proc. Natl. Acad. Sci. USA 2004, 101, 6472-6477. [CrossRef]

526. Salazar, G.; Cullen, A.; Huang, J.; Zhao, Y.; Serino, A.; Hilenski, L.; Patrushev, N.; Forouzandeh, F.; Hwang, H.S. SQSTM1/p62 and PPARGC1A/PGC-1alpha at the interface of autophagy and vascular senescence. Autophagy 2020, 16, 1092-1110. [CrossRef]

527. Michaëlsson, K.; Wolk, A.; Langenskiöld, S.; Basu, S.; Warensjö Lemming, E.; Melhus, H.; Byberg, L. Milk intake and risk of mortality and fractures in women and men: Cohort studies. BMJ 2014, 349, g6015. [CrossRef]

528. Tognon, G.; Nilsson, L.M.; Shungin, D.; Lissner, L.; Jansson, J.H.; Renström, F.; Wennberg, M.; Winkvist, A.; Johansson, I. Nonfermented milk and other dairy products: Associations with all-cause mortality. Am. J. Clin. Nutr. 2017, 105, 1502-1511. [CrossRef]

529. Michaëlsson, K.; Wolk, A.; Melhus, H.; Byberg, L. Milk, fruit and vegetable, and total antioxidant intakes in relation to mortality rates: Cohort studies in women and men. Am. J. Epidemiol. 2017, 185, 345-361. [CrossRef]

530. Michaëlsson, K.; Byberg, L. Mixing of apples and oranges in milk research: A cohort analysis of non-fermented milk intake and all-cause mortality. Nutrients 2020, 12, 1393. [CrossRef]

531. Larsson, S.C.; Virtamo, J.; Wolk, A. Dairy consumption and risk of stroke in Swedish women and men. Stroke 2012, 43, 1775-1780 [CrossRef] [PubMed]

532. Michaëlsson, K.; Wolk, A.; Lemming, E.W.; Melhus, H.; Byberg, L. Intake of milk or fermented milk combined with fruit and vegetable consumption in relation to hip fracture rates: A cohort study of Swedish women. J. Bone Miner. Res. 2018, 33, 449-457. [CrossRef]

533. Hollox, E. Evolutionary genetics: Genetics of lactase persistence-Fresh lessons in thehistory of milk drinking. Eur. J. Hum. Genet. 2005, 13, 267-269. [CrossRef] [PubMed]

534. Curry, A. Archaeology: The milk revolution. Nature 2013, 500, 20-22. [CrossRef]

535. Salque, M.; Bogucki, P.I.; Pyzel, J.; Sobkowiak-Tabaka, I.; Grygiel, R.; Szmyt, M.; Evershed, R.P. Earliest evidence for cheese making in the sixth millennium BC in northern Europe. Nature 2013, 493, 522-525. [CrossRef]

536. O'Leary, V.S.; Woychik, J.H. Utilization of lactose, glucose and galactose by a mixed culture of Streptococcus thermophilus and Lactobacillus bulgaricus in milk treated with lactase enzyme. Appl. Environ. Microbiol. 1976, 32, 89-94. [CrossRef]

537. Thomas, T.D.; Crow, V.L. Selection of galactose-fermenting Streptococcus thermophilus in lactose-limited chemostat cultures Appl. Environ. Microbiol. 1984, 48, 186-191. [CrossRef] [PubMed]

538. Michel, V.; Martley, F.G. Streptococcus thermophilus in cheddar cheese-Production and fate of galactose. J. Dairy. Res. 2001, 68, 317-325. [CrossRef]

539. Wilkinson, M.G.; LaPointe, G. Invited review: Starter lactic acid bacteria survival in cheese: New perspectives on cheese microbiology. Wilkinson MG, LaPointe, G. Invited review: Starter lactic acid bacteria survival in cheese: New perspectives on cheese microbiology. J. Dairy Sci. 2020, 103, 10963-10985. [CrossRef]

540. Liu, M.; Bayjanov, J.R.; Renckens, B.; Nauta, A.; Siezen, R.J. The proteolytic system of lactic acid bacteria revisited: A genomic comparison. BMC Genomics 2010, 297, 164-172. [CrossRef] [PubMed]

541. Rodríguez-Serrano, G.M.; García-Garibay, M.; Cruz-Guerrero, A.E.; Gómez-Ruiz, L.; Ayala-Niño, A.; Castañeda-Ovando, A.; González-Olivares, L.G. Proteolytic system of Streptococcus thermophilus. J. Microbiol. Biotechnol. 2018, 28, 1581-1588. [CrossRef] [PubMed]

542. Liljeberg Elmståhl, H.; Björck, I. Milk as a supplement to mixed meals may elevate postprandial insulinaemia. Eur. J. Clin. Nutr. 2001, 55, 994-999. [CrossRef] [PubMed]

543. Filer, D.; Thompson, M.A.; Takhaveev, V.; Dobson, A.J.; Kotronaki, I.; Green, J.W.M.; Heinemann, M.; Tullet, J.M.A.; Alic, N. RNA polymerase III limits longevity downstream of TORC1. Nature 2017, 552, 263-267. [CrossRef] [PubMed]

544. Wood, K.C.; Sabatini, D.M. Growth signaling at the nexus of stem cell life and death. Cell Stem Cell 2009, 5, 232-234. [CrossRef] [PubMed] 
545. Castilho, R.M.; Squarize, C.H.; Chodosh, L.A.; Williams, B.O.; Gutkind, J.S. mTOR mediates Wnt-induced epidermal stem cell exhaustion and aging. Cell Stem Cell 2009, 5, 279-289. [CrossRef]

546. Ramos, F.J.; Kaeberlein, M. Ageing: A healthy diet for stem cells. Nature 2012, 486, 477-478. [CrossRef]

547. Yilmaz, Ö.H.; Katajisto, P.; Lamming, D.W.; Gültekin, Y.; Bauer-Rowe, K.E.; Sengupta, S.; Birsoy, K.; Dursun, A.; Yilmaz, V.O.; Selig, M.; et al. mTORC1 in the Paneth cell niche couples intestinal stem-cell function to calorie intake. Nature 2012, 486, 490-495. [CrossRef]

548. Johnson, S.C.; Rabinovitch, P.S.; Kaeberlein, M. mTOR is a key modulator of ageing and age-related disease. Nature 2013, 493, 338-345. [CrossRef]

549. Perl, A. mTOR activation is a biomarker and a central pathway to autoimmune disorders, cancer, obesity, and aging. Ann. N. Y. Acad. Sci. 2015, 1346, 33-44. [CrossRef]

550. Igarashi, M.; Guarente, L. mTORC1 and SIRT1 cooperate to foster expansion of gut adult stem cells during calorie restriction. Cell 2016, 166, 436-450. [CrossRef]

551. Saxton, R.A.; Sabatini, D.M. mTOR signaling in growth, metabolism, and disease. Cell 2017, 168, 960-976. [CrossRef] [PubMed]

552. Weichhart, T. mTOR as regulator of lifespan, aging, and cellular senescence: A mini-review. Gerontology 2018, 64, 127-134. [CrossRef] [PubMed]

553. Stallone, G.; Infante, B.; Prisciandaro, C.; Grandaliano, G. mTOR and aging: An old fashioned dress. Int. J. Mol. Sci. 2019, $20,2774$. [CrossRef] [PubMed]

554. Boutouja, F.; Stiehm, C.M.; Platta, H.W. mTOR: A cellular regulator interface in health and disease. Cells 2019, 8, 18. [CrossRef] [PubMed]

555. Papadopoli, D.; Boulay, K.; Kazak, L.; Pollak, M.; Mallette, F.; Topisirovic, I.; Hulea, L. mTOR as a central regulator of lifespan and aging. F1000Res. 2019, 8, F1000. [CrossRef] [PubMed] 